Water-Resources Investigations Report 01-4240

\title{
Standard Errors of Annual Discharge and Change in Reservoir Content Data from Selected Stations in the Lower Colorado River Streamflow- Gaging Station Network, 1995-99
}




\title{
Standard Errors of Annual Discharge and Change in Reservoir Content Data from Selected Stations in the Lower Colorado River Streamflow-Gaging Station Network, 1995-99
}

\author{
By David W. Anning
}

Water-Resources Investigations Report 01—4240

Prepared in cooperation with

BUREAU OF RECLAMATION 


\section{U.S. DEPARTMENT OF THE INTERIOR \\ GALE A. NORTON, Secretary}

U.S. GEOLOGICAL SURVEY

Charles G. Groat, Director

The use of firm, trade, and brand names in this report is for identification purposes only and does not constitute endorsement by the U.S. Geological Survey.

For additional information write to:

District Chief

U.S. Geological Survey

Water Resources Division

520 N. Park Avenue, Suite 221

Tucson, AZ 85719-5035
Copies of this report can be purchased from:

U.S. Geological Survey

Information Services

Box 25286

Federal Center

Denver, C0 80225-0046

Information about U.S. Geological Survey programs in Arizona is available online at http://az.water.usgs.gov. 


\section{CONTENTS}

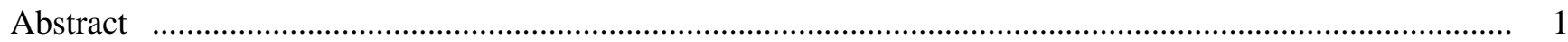

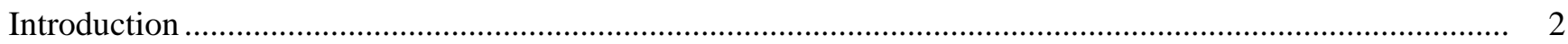

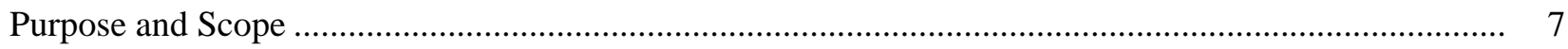

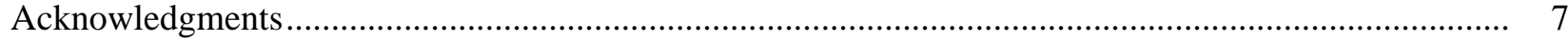

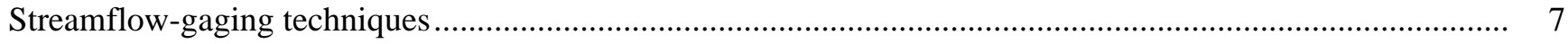

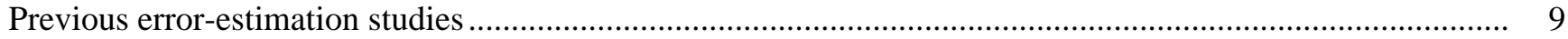

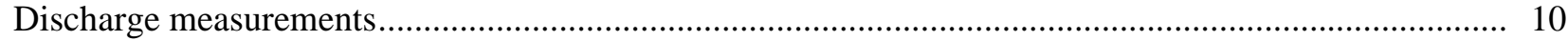

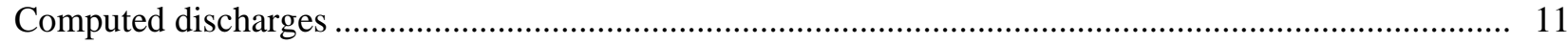

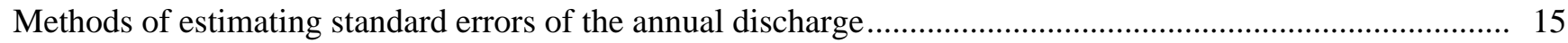

Methods of estimating the standard error of the annual change in reservoir content .................................... 25

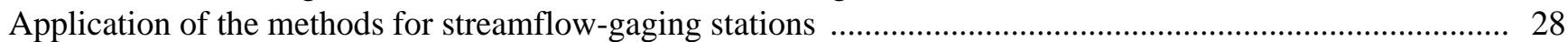

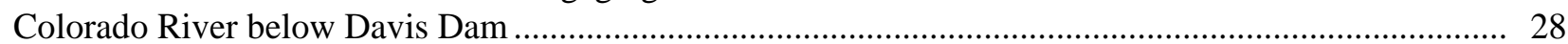

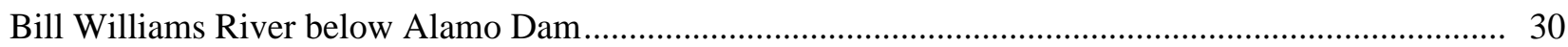

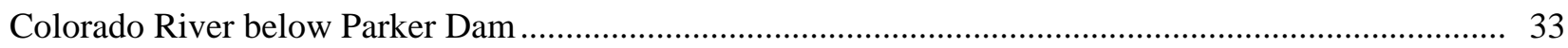

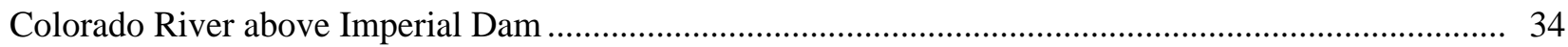

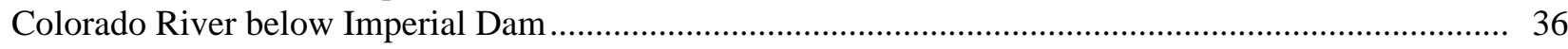

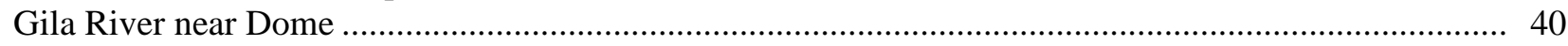

Colorado River at the Northerly International Boundary with Mexico .............................................. 40

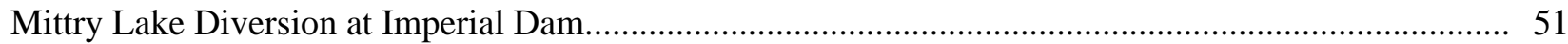

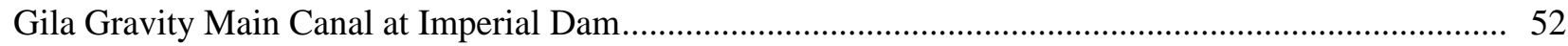

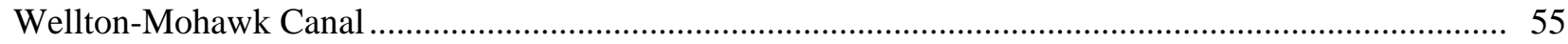

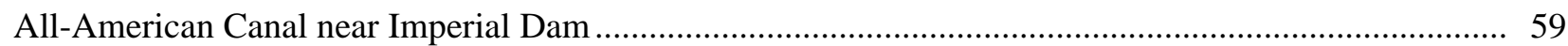

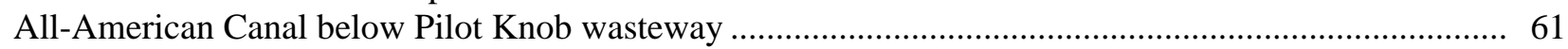

Application of methods for reservoir-content gaging stations ............................................................ 64

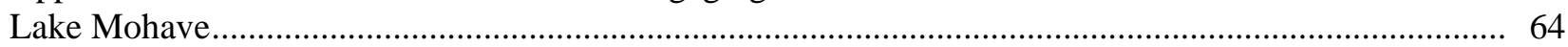

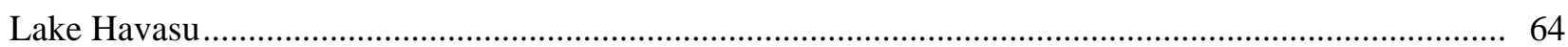

Summary of uncertainty in the annual discharge and the annual change in reservoir content ........................ 65

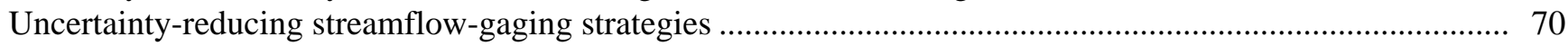

Streamflow-Gaging Strategies that Reduce Process Variance................................................... 70

Streamflow-Gaging Strategies that Reduce Measurement Variance …............................................... 72

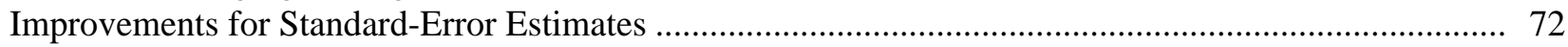

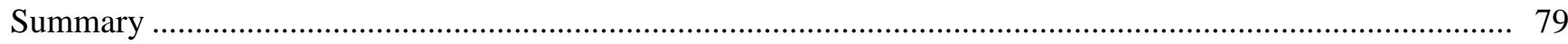

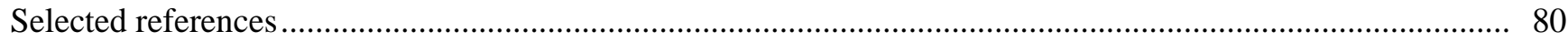




\section{FIGURES}

1. Map showing study area and location of streamflow- and reservoir-contents gaging stations between Hoover Dam and the southerly international boundary with Mexico

2. Schematic diagram showing streamflow- and reservoir-contents gaging stations between Hoover Dam and Morelos Dam ............................................................................. 5

3-11. Graphs showing:

3. Shifting the discharge rating on the basis of a discharge measurement ..................................... 9

4. Conceptual model for uncertainty in the discharge-rating shift .............................................. 13

5. Conceptual model for uncertainty in computed instantaneous discharge as affected by measurement variance, variance of the process affecting the discharge rating, and serial correlation of that process. Vertical dashed lines indicate time of discharge measurement collection.

A. Base conditions for measurement variance, process variance, and serial correlation............. 14

B. Larger measurement variance, same process variance and serial correlation as base conditions .....

C. Larger process variance, same measurement variance and serial correlation as base conditions

D. Less serial correlation, same measurement variance and process variance as base conditions

E. Shorter time intervals between discharge measurements, same measurement variance, process variance, and serial correlation as base conditions

6. Stage-discharge rating for Colorado River at the northerly international boundary with Mexico, January 1, 1995, to December 31, 1999

7. Residuals from the stage-discharge rating for Colorado River at the northerly international boundary with Mexico, January 1, 1995, to December 31, 1999

8. Non-time-dependent stage-discharge rating for Colorado River at the northerly international boundary with Mexico, July 28, 1995, to January 16, 1997

9. Residuals from the non-time-dependent stage-discharge rating for Colorado River at the northerly international boundary with Mexico, July 28, 1995, to January 16,1997

10. Relation between discharge and time-adjusted gage height for Colorado River at the northerly international boundary with Mexico, July 28, 1995, to January 16, 1997

11. Residuals from time-dependent stage-discharge rating for Colorado River at the northerly international boundary with Mexico, July 28, 1995, to January 16,1997

12-13. Semivariograms of discharge-related residuals for:

12. Colorado River at the northerly international boundary with Mexico, July 28, 1995 , to January 16, 1997 22

13. Colorado River below Davis Dam, January 5, 1988, to December 31, 1999 23

14-15. Graphs showing 
14. Variance of estimate of the annual discharge for 1996 at Colorado River at the northerly international boundary with Mexico as a function of the number of discharge measurements used to compute the discharge record that year

15. Time series of the instantaneous water-surface elevation and the LOWESS smooth of that series for December 26, 1999, to January 5, 2000.

A. Lake Mohave at Davis Dam ....

B. Lake Havasu near Parker Dam

16-18. Semivariograms of discharge-rating residuals for:

16. Semivariograms of discharge-rating residuals for Colorado River below

Davis Dam, January 5, 1988, to December 31, 1999

17. Semivariograms of discharge-rating residuals for Bill Williams River below Alamo Dam.

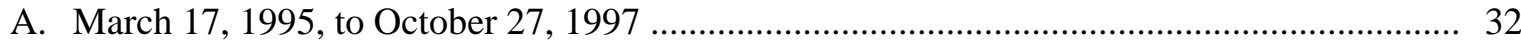

B. March 20, 1998, to December 31, 1999

18. Semivariograms of discharge-rating residuals for Colorado River below Parker Dam, January 1, 1995, to December 31, 1999

19. Schematic diagram showing streamflow-gaging stations used to compute discharge at

Colorado River above Imperial Dam and at Colorado River below Imperial Dam.

20-29. Semivariograms of discharge-rating residuals for:

20. Streamflow-gaging stations used to compute discharge at Colorado River below Imperial Dam.

A. Desilting-basin discharges, seepage, and leakage from the California sluiceway, January 1, 1979, to December 31, 1999

B. California sluiceway releases, January 1, 1979, to December 31, 1999

21. Gila River near Dome.

A. June 28, 1994, to April 5, 1995

B. April 6, 1995, to September 25, 1995

C. September 26, 1995, to December 31, 1996

D. January 1,1997 , to July 30,1998

E. July 31,1998 , to December 31,1999

22. Colorado River at the northerly international boundary with Mexico, for 17 different discharge-rating periods between 1995 and 1999

23. Mittry Lake Diversion at Imperial Dam, January 1, 1995, to December 31, 1999

24. Stilling-well gage on the Gila Gravity Main Canal at Imperial Dam, September 8, 1993, to December 31, 1999

25. Acoustic-velocity meter gage on the Gila Gravity Main canal at Imperial Dam, January 1, 1996, to December 31, 1999

26. Radial-gates gage on the Wellton-Mohawk Canal, December 2, 1979, to December 31, 1999

27. Acoustic-velocity meter gage on the Wellton-Mohawk Canal, January 1, 1996, to December 31, 1999

28. All-American Canal near Imperial Dam, January 1, 1995, to December 31, 1999

29. All-American Canal below Pilot Knob Wasteway.

A. January 1, 1995, to December 3, 1996.

B. December 4, 1996, to December 21, 1998

C. December 22, 1998, to May 15, 2000 
30-35. Graphs showing:

30. Annual discharge at streamflow-gaging stations 1995-99.

31. Standard error of the annual discharge and of the annual change in reservoir content at surface-water gaging stations, 1995-99

32. Standard error of the annual discharge, as a percentage, at streamflow-gaging stations, 1995-99

33. Variance of estimate of the annual discharge and of the annual change in reservoir content at surface-water gaging stations, 1995-99

34. Comparison of the variance of estimate of the annual discharge for the discharge-rating shift determined on the basis of one or two discharge measurements per site visit

35. Variance of discharge-rating residuals, measurement variance as determined from the semivariogram, and measurement variance determined from the error of individual discharge measurements as estimated by using the Sauer and Meyer (1992) method 


\section{TABLES}

1. Streamflow- and reservoir-contents gaging stations for which the variance of estimate of the annual discharge or annual change in reservoir content is required for use in the Lower Colorado River Accounting System ................................................................ 6

2. Stream-gaging techniques and generalized rating equations used to compute discharge at streamflow-gaging stations.

3. Summary of error-analysis results for the annual discharge at Colorado River below Davis Dam....

4. Summary of error-analysis results for the annual discharge at Bill Williams River below Alamo Dam.

5. Summary of error-analysis results for the annual discharge at Colorado River below Parker Dam...

6. Summary of error-analysis results for the annual discharge at Colorado River above Imperial Dam .....

7. Summary of error-analysis results for the annual discharge at Colorado River below Imperial Dam.

8. Summary of error-analysis results for the annual discharge at Gila River near Dome.

9. Summary of error-analysis results for the annual discharge at Colorado River at the northerly international boundary with Mexico

10. Summary of error-analysis results for the annual discharge at Mittry Lake Diversion at Imperial Dam....

11. Summary of error-analysis results for the annual discharge at Gila Gravity Main Canal at Imperial Dam (stilling-well gage)

12. Summary of error-analysis results for the annual discharge at Gila Gravity Main Canal at Imperial Dam (acoustic velocity meter gage).

13. Summary of error-analysis results for the annual discharge at Wellton-Mohawk Canal (radial-gates gage)

14. Summary of error-analysis results for the annual discharge at Wellton-Mohawk Canal (acoustic velocity meter gage).

15. Summary of error-analysis results for the annual discharge at All-American Canal near Imperial Dam.

16. Summary of error-analysis results for the annual discharge at All-American Canal below Pilot Knob wasteway.....

17. Summary of error-analysis results for the annual change in content of Lake Mohave ..................... 64

18. Summary of error-analysis results for the annual change in content of Lake Havasu ....

19. Average annual variance of estimate and standard error of the annual discharge, 1995-99, at selected streamflow-gaging stations based on the existing streamflow-gaging strategy and on a proposed streamflow-gaging strategy ..... 71

20. Residuals from the Lower Colorado River Accounting System, by reach and year 77

21. Comparison of annual discharge data and comparison of measured discharge with computed instantaneous discharge data from the two streamflow-gaging stations on the Gila Gravity Main Canal at Imperial Dam and on Wellton-Mohawk Canal 


\begin{tabular}{|c|c|c|}
\hline Multiply & By & To obtain \\
\hline \multicolumn{3}{|c|}{ Length } \\
\hline foot $(\mathrm{ft})$ & 0.3048 & meter \\
\hline mile (mi) & 1.609 & kilometer \\
\hline \multicolumn{3}{|c|}{ Volume } \\
\hline acre-foot (acre-ft) & 1,233 & cubic meter \\
\hline acre-foot (acre-ft) & 0.001233 & cubic hectometer \\
\hline \multicolumn{3}{|c|}{ Flow rate } \\
\hline acre-foot per year (acre-ft/yr) & 1,233 & cubic meter per year \\
\hline acre-foot per year (acre-ft/yr) & 0.001233 & cubic hectometer per year \\
\hline cubic foot per second $\left(\mathrm{ft}^{3} / \mathrm{s}\right)$ & 0.02832 & cubic meter per second \\
\hline cubic foot per second $\left(\mathrm{ft}^{3} / \mathrm{s}\right)$ & 1.98347106 & acre-foot per day \\
\hline
\end{tabular}

\title{
ACRONYMS
}

$\begin{aligned} \text { AVM } & \text { Acoustic velocity meter } \\ \text { ADCP } & \text { Acoustic doppler current profile } \\ \text { IBWC } & \text { International Boundary and Water Commission } \\ \text { IID } & \text { Imperial Irrigation District } \\ \text { LCRAS } & \text { Lower Colorado River Accounting System } \\ \text { NIB } & \text { Northerly international boundary with Mexico } \\ \text { BOR } & \text { Bureau of Reclamation } \\ \text { USGS } & \text { U.S. Geological Survey }\end{aligned}$

\section{SYMBOLS}

\author{
$A_{i} \quad$ Reservoir surface-area at time i \\ $c_{0}, c_{1}, c_{2} \quad$ Constants in discharge-rating equations \\ $C U_{d} \quad$ Domestic, commercial, and industrial consumptive use \\ $C(\Delta) \quad$ Covariance of the discharge-rating residuals $\Delta$ days apart \\ E Open-water evaporation \\ $E T_{p h t} \quad$ Total estimated phreatophyte evapotranspiration \\ $E T_{\text {crop }}$ Total estimated crop evapotranspiration \\ $h \quad$ Stream or reservoir stage \\ $h_{g} \quad$ Gate opening \\ $h_{1} \quad$ Forebay stage \\ $h_{2} \quad$ Afterbay stage \\ $i, j \quad$ Index variables
}




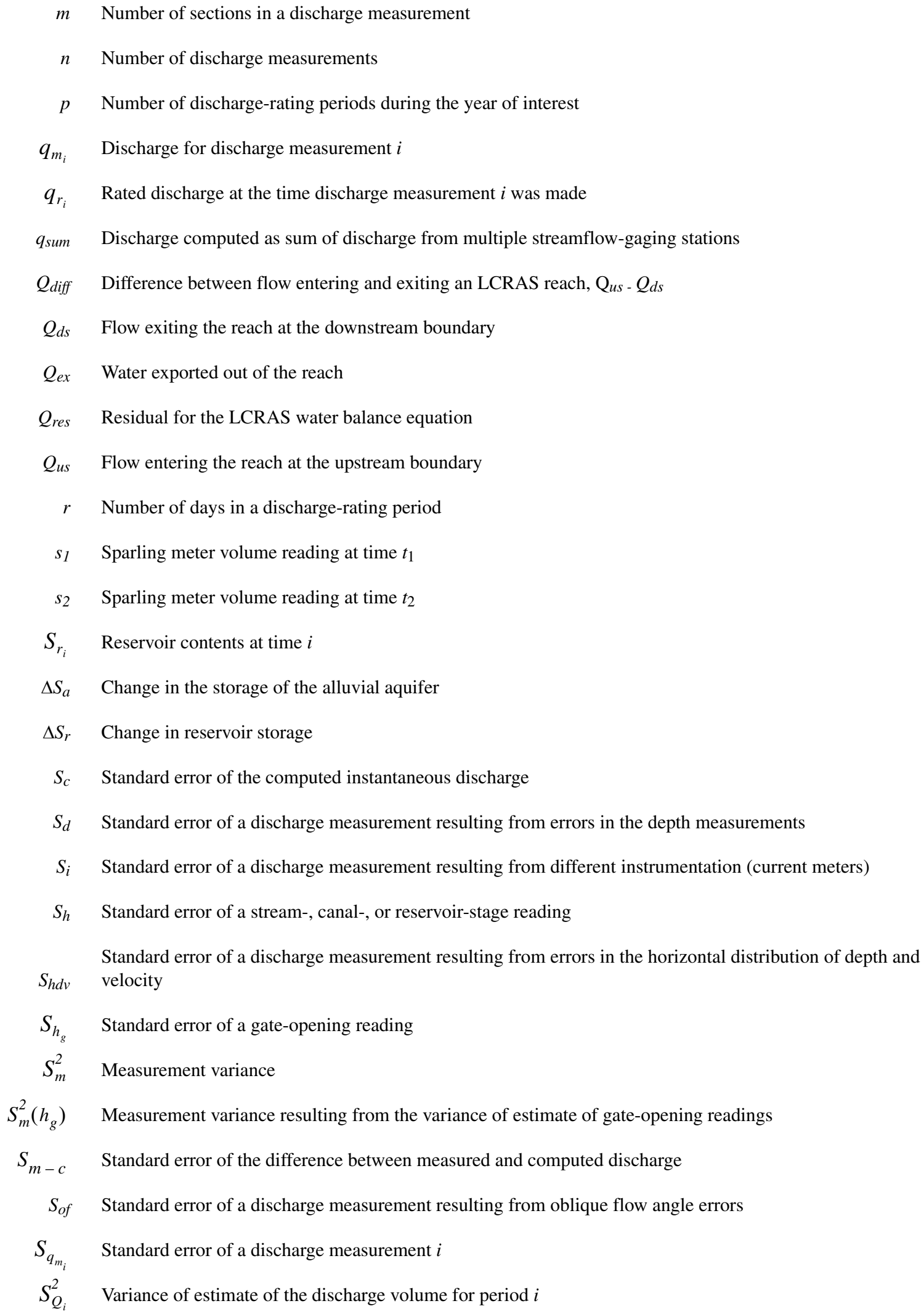


$S_{\bar{Q}}^{2} \quad$ Variance of estimate of the average annual discharge

$S_{p r}^{2} \quad$ Process variance

$S_{r_{i}} \quad$ Reservoir content for reservoir-stage reading $i$

Standard error of a discharge measurement resulting from uncertainty in the vertical-velocity

$S_{S} \quad$ distribution

$S_{s b} \quad$ Standard error of a discharge measurement resulting from biased width measurements

$S_{r_{i}} \quad$ Reservoir contents at time $i$

$S_{s d} \quad$ Standard error of a discharge measurement resulting from biased depth measurements

$S_{S_{r_{i}}} \quad$ Standard error of reservoir content reading $i$

$S_{\Delta S_{r}} \quad$ Standard error of the change in reservoir content

$S_{s v} \quad$ Standard error of a discharge measurement resulting from biased velocity measurements

$S_{t} \quad$ Standard error of a discharge measurement resulting from the pulsation of velocity

$S_{z}^{2} \quad$ Variance of the discharge-rating residuals

$t$ Time

$T_{r m} \quad$ Measured tributary inflow to the reach

$T_{\text {rum }} \quad$ Unmeasured tributary inflow to the reach

$v_{i} \quad$ Acoustic velocity meter index velocity for discharge measurement $i$

$z \quad$ Average discharge-rating residual

$z_{i} \quad$ Discharge-rating residual, or shift, for discharge measurement $i$

a Percent error of discharge measurements

$\alpha_{i} \quad$ Percent error of discharge measurement $i$

$\alpha_{e} \quad$ Effective percent error for discharge measurements

$\Delta \quad$ Time interval between measurements, in days

$\gamma(\Delta) \quad$ Gamma function of covariance

$\rho \quad$ The one-day serial correlation coefficient for the discharge-rating residuals 


\title{
Standard Errors of Annual Discharge and Change in Reservoir Content Data from Selected Stations in the Lower Colorado River Streamflow- Gaging Station Network, 1995-99
}

\author{
By David W. Anning
}

\begin{abstract}
The Bureau of Reclamation is currently (1995-2001) testing the Lower Colorado River Accounting System as a method to estimate the consumptive use of Colorado River water by diverters from Hoover Dam to Mexico. Consumptive use is estimated in the Lower Colorado River Accounting System method, in part, on the basis of the annual discharge or annual change in reservoir contents, as well as the variance of estimate of the annual discharge or the annual change in reservoir contents at several surface-water gaging stations in the lower Colorado River stream-gaging network. The standard error and the variance of estimate were determined for the annual discharge at 14 streamflow-gaging stations and for the annual change in content at 2 reservoir-content gaging stations used in the Lower Colorado River Accounting System for calendar years 1995-99.
\end{abstract}

The standard error of the annual discharge was determined by using modifications to an existing method that assumes that the uncertainty in the discharge-rating shift is the main source of uncertainty in computed discharges and that the discharge-rating shift behaves as a first-order Markovian process. The method uses Kalman filtering of a first-order Markovian process as a statistical analogy to computing streamflow with a shifted discharge rating. Temporally unbiased residuals from a discharge rating are used as a surrogate for the actual shifts used to compute discharge. The standard error of the annual discharge is determined by using Kalman-filter theory and estimates of four parameters: (1) the measurement variance of the discharge measurements used to determine the discharge-rating shift, (2) the process variance of the discharge-rating residuals, (3) the serial correlation of the discharge-rating residuals, and (4) the frequency of the discharge measurements. The existing methodology was improved by estimating the measurement variance from a semivariogram of the discharge-rating residuals, rather than on the basis of empirically derived error estimates for discharge measurements. The process variance and serial correlation of the discharge-rating residuals are estimated from the semivariogram, rather than a variogram, of the discharge-rating residuals. The empirically derived estimates are based on characteristics of the discharge measurements such as number of depth and velocity observation sections, type of current meter, and bed material composition and stability. Measurement variance determined from the semivariograms was site specific and is therefore considered a better estimate than measurement variance determined from the empirically-derived estimates. The method of estimating the standard error of the annual discharge requires the assumption of unbiased discharge-rating residuals, and for this reason, the standard errors presented in this report only represent the random error in the annual discharge data. Estimates of the standard error of the annual change in reservoir content were determined on the basis of the reservoir-surface area and the standard error of reservoir-stage readings. 
The standard error of the annual discharge, as a percentage, ranged from 0.11 percent for the AllAmerican Canal near Imperial Dam in 1998 to 12.3 percent for the Colorado River below Imperial Dam in 1996. The standard error of the annual discharge was less than 2 percent for all 5 years for 11 of the 14 streamflow-gaging stations. In terms of flow volume, the standard error of the annual discharge ranged from 97 acre-feet for the Mittry Lake Diversions in 1995 to 77,000 acre-feet for the Colorado River at the northerly international boundary with Mexico in 1998. In general, the standard error of the annual discharge, as a percentage, was smallest at streamflow-gaging stations on the main stem of the Colorado River; however, the standard error of the annual discharge in acre-feet was largest at these stations because of the large annual discharge on the main stem. The standard error of the annual change in content for the two reservoirs ranged from 1,590 acre-feet for Lake Havasu in 1996 to 2,790 acre-feet for Lake Mohave in 1995.

The variance of estimate of the annual discharge for a streamflow-gaging station can be reduced by making additional discharge measurements; either by increasing the number of discharge measurements made per site visit, or by increasing the frequency of site visits. Measurement error can be reduced by using the average shift for two or more discharge measurements made during a site visit. For a streamflow-gaging station where measurement error is much greater than process error and the serial correlation of the discharge-rating residuals is high, an improved gaging strategy would involve making multiple discharge measurements per site visit. In contrast, for a streamflow-gaging station where process error is much greater than measurement error and the serial correlation of discharge-rating residuals is low, the gaging strategy would consist of several single discharge-measurement site visits. For a given operating cost or for a given variance of estimate of the annual discharge at a streamflow-gaging station, the optimal site-visit and discharge-measurement strategy can be determined, providing that the travel costs as well as the measurement variance, process variance, and serial correlation of discharge-rating residuals are known.

\section{INTRODUCTION}

The Colorado River Compact of 1922 apportions the waters of the Colorado River between the upper basin States and lower basin States (U.S. Congress, 1948, p. A17-A22). The requirement for participation of the U.S. Geological Survey (USGS) and the Bureau of Reclamation (BOR) is stated in Article V:

The chief official of each signatory State charged with the administration of water rights, together with the Director of the United States Reclamation Service and the Director of the United States Geological Survey shall cooperate, ex-officio:

(a) To promote the systematic determination and coordination of the facts as to flow, appropriation, consumption, and use of water in the Colorado River Basin, and the interchange of available information in such matters.

Water in the lower Colorado River is apportioned among the States of California, Arizona, and Nevada by the Boulder Canyon Project Act of December 21, 1928 (U.S. Congress, 1948, p. A213-A225) and confirmed by the U.S. Supreme Court decree, 1964, Arizona v. California, in terms of consumptive use. The decree is specific about the responsibility of the Secretary of the Interior to account for consumptive use of water from the main stem. Article V of the decree (U.S. Supreme Court, 1964) states in part:

The United States shall prepare and maintain, or provide for the preparation and maintenance of, and shall make available, annually and at such shorter intervals as the Secretary of the Interior shall deem necessary or advisable, for inspection by interested persons at all reasonable times and at a reasonable place or places, complete, detailed and accurate records of: *** 
$* * *(B)$ Diversions of water from the main stem, return flow of such water to the stream as is available for consumptive use in the United States or in satisfaction of the Mexican treaty obligation, and consumptive use of such water. These quantities shall be stated separately as to each diverter from the main stem, each point of diversion, and each of the States of Arizona, California, and Nevada.

The BOR publishes an annual report (Bureau of Reclamation, 1965-99) that contains records of flow through regulatory structures, diversions, return flows, and consumptive use of water by individual water users. Much of the hydrologic information contained in this annual report is furnished by the USGS (Condes de la Torre, 1982, p. 5-7). A detailed description of the lower Colorado River and the streamflow-gaging stations used to provide flow information included in the BOR's annual report is presented in Owen-Joyce and Raymond (1996, p. 8-20).

The USGS, in cooperation with the BOR, developed the Lower Colorado River Accounting System (LCRAS; Owen-Joyce and Raymond, 1996) as a method to determine the annual consumptive use of Colorado River water by diverters from Hoover Dam to Mexico. The LCRAS is being tested by the BOR for use as the method of calculating the consumptive use of Colorado River water and is based on a water balance that is applied to four reaches of the lower Colorado River: Hoover Dam to Davis Dam, Davis Dam to Parker Dam, Parker Dam to Imperial Dam, and Imperial Dam to Mexico (fig. 1). The water balance equation used by the BOR is:

$$
Q_{\text {res }}=Q_{\text {diff }}+T_{r m}+T_{\text {rum }}-Q_{e x}-E-C U_{d}-E T_{p h t}-E T_{c r o p}-\Delta S_{r}-\Delta S_{a}
$$

where

$$
\begin{aligned}
Q_{r e s} & =\text { residual (algebraic sum of errors); } \\
Q_{d i f f} & =\text { difference between flow entering and exiting the reach, } \mathrm{Qus}_{\mathrm{us}} \mathrm{Q}_{\mathrm{ds}} \\
Q_{u s} & =\text { flow entering the reach at the upstream boundary; } \\
Q_{d s} & =\text { flow exiting the reach at the downstream boundary; } \\
T_{r m} & =\text { measured tributary inflow to reach; } \\
T_{r u m} & =\text { unmeasured tributary inflow to the reach; } \\
Q_{e x} & =\text { water exported out of the basin; } \\
E & =\text { open-water evaporation; } \\
C U_{d} & =\text { domestic, including municipal and industrial use; } \\
E T_{p h t} & =\text { total estimated phreatophyte evapotranspiration; } \\
E T_{c r o p} & =\text { total estimated crop evapotranspiration; } \\
\Delta S_{r} & =\text { change in reservoir storage; and } \\
\Delta S_{a} & =\text { change in the storage of the alluvial aquifer (Bureau of Reclamation, 2000). }
\end{aligned}
$$

The components of the water balance (equation 1) are measured where possible and estimated otherwise. Many of the components are measured by streamflow- or reservoir-contents gaging stations. The sum of the waterbalance components typically does not equal zero because each component contains some uncertainty. To force the sum of the components of equation 1 to equal zero, a portion of $Q_{\text {res }}$ is distributed to each component on the basis of the variance of estimate (squared standard error) of that component. Therefore, methods must be established for determining the variance of estimate of the components in the water balance that are defined by streamflow- or reservoir-contents gaging stations.

The BOR requested the USGS to determine and report the variance of estimate of the annual discharge and annual change in reservoir content data that are used in the LCRAS (figs. 1 and 2; table 1). In response to this request, the USGS began a study in 1999 to (1) determine and apply the appropriate procedures for estimating the variance of estimate, in acre- $\mathrm{ft}^{2}$, of the annual discharge or annual change in content for each surface-water gaging station listed in table 1, (2) facilitate the incorporation of the error computation procedures into the USGS annual records computation and reporting process, and (3) present alternative gaging strategies that would either reduce the variance of estimate of the annual discharge or change in reservoir content, or improve the quality of the error estimates. 
EXPLANATION

$1 \Delta$ CONTINUOUS-RECORD STREAMFLOWGAGING STATION-Number corresponds to site number in table 1

$2 \Delta$ CONTINUOUS-RECORD RESERVOIRCONTENTS GAGING STATIONNumber corresponds to site number in table 1

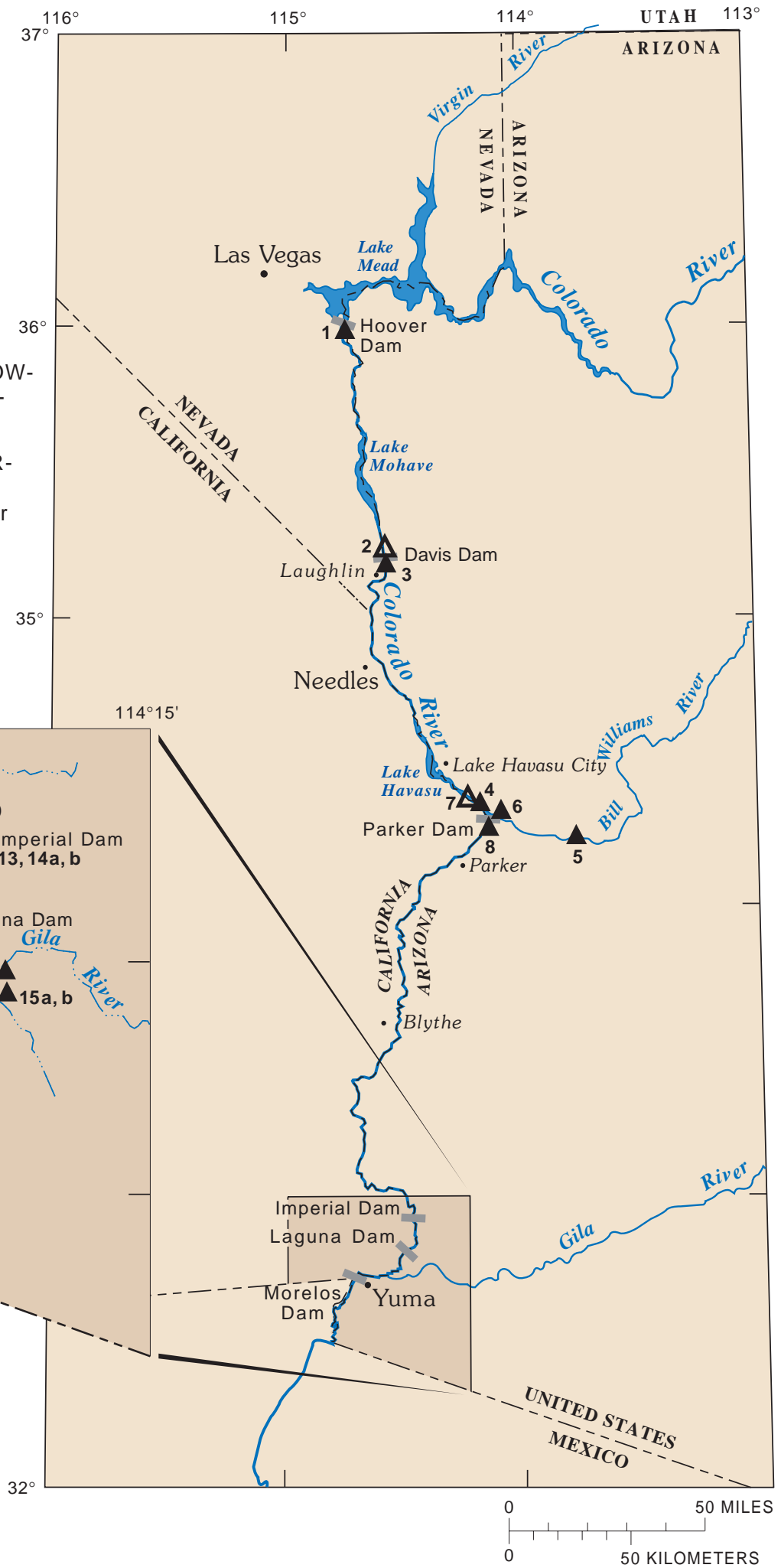

Figure 1. Study area and location of streamflow- and reservoir-contents gaging stations between Hoover Dam and the southerly international boundary with Mexico. 


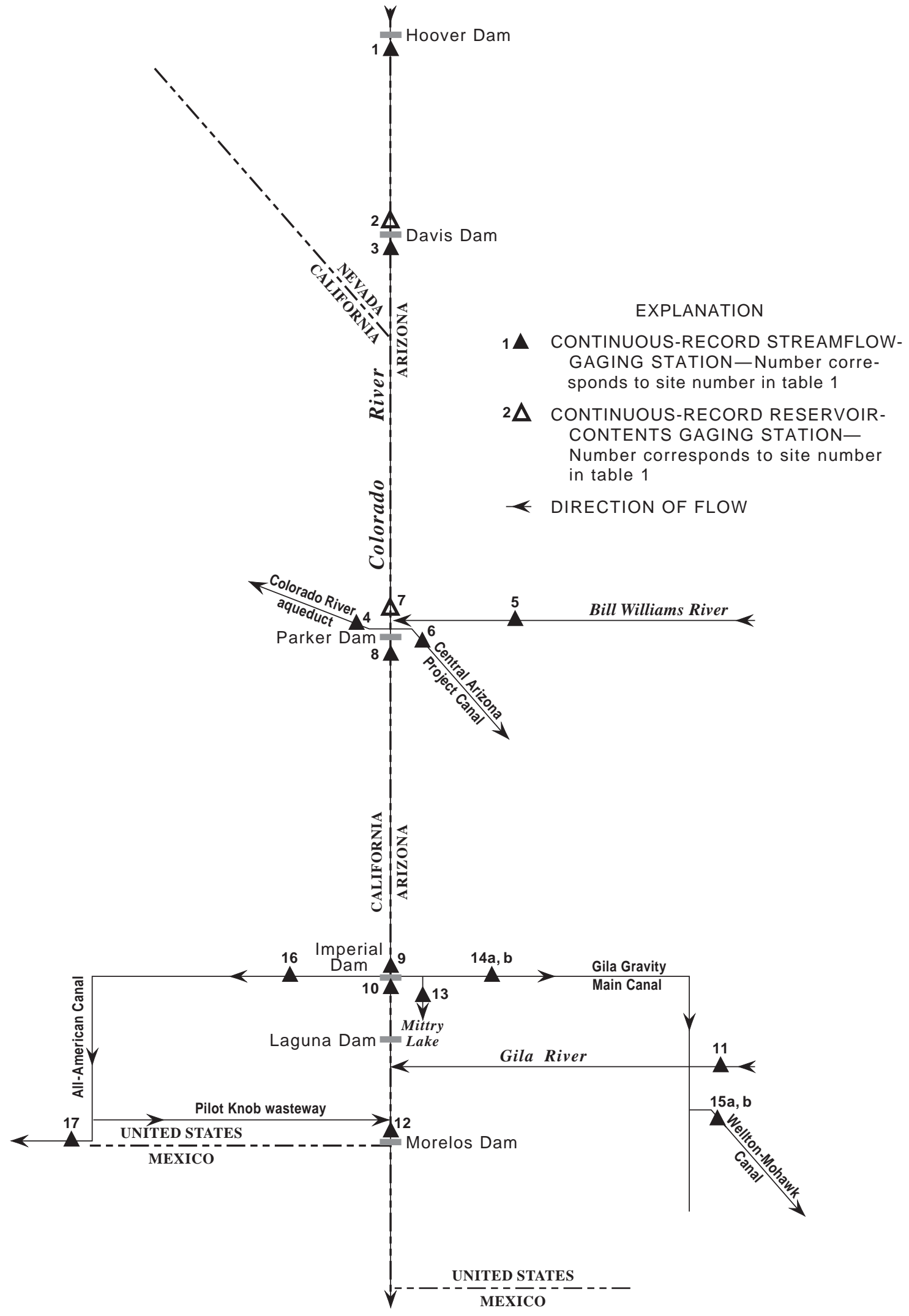

Figure 2. Streamflow- and reservoir-contents gaging stations between Hoover Dam and Morelos Dam. 
Table 1. Streamflow- and reservoir-contents gaging stations for which the variance of estimate of the annual discharge or annual change in reservoir content is required for use in the Lower Colorado River Accounting System.

[AVM, acoustic velocity meter; BOR, Bureau of Reclamation; USGS, U.S. Geological Survey; ---, not a U.S. Geological Survey streamflow- gaging station. Site number is used to indicate station locations in figures 1 and 2]

\begin{tabular}{|c|c|c|c|}
\hline $\begin{array}{l}\text { Site } \\
\text { number }\end{array}$ & $\begin{array}{l}\text { USGS } \\
\text { station } \\
\text { number }\end{array}$ & Station name & Gaging technique \\
\hline 1 & 09421500 & Colorado River below Hoover Dam & AVMs in closed conduits \\
\hline 2 & 09422500 & Lake Mohave at Davis Dam ${ }^{1}$ & Relation of reservoir contents to reservoir stage \\
\hline 3 & 09423000 & Colorado River below Davis Dam & Relation of discharge to stream stage \\
\hline 4 & 09424150 & Colorado River Aqueduct near Parker Dam & AVMs in closed conduits \\
\hline 5 & 09426000 & Bill Williams River below Alamo Dam & Relation of discharge to stream stage \\
\hline 6 & 09426650 & $\begin{array}{l}\text { Central Arizona Project Canal at Havasu Pumping } \\
\text { Plant, near Parker }\end{array}$ & AVMs in closed conduits \\
\hline 7 & 09427500 & Lake Havasu near Parker Dam ${ }^{1}$ & Relation of reservoir contents to reservoir stage \\
\hline 8 & 09427520 & Colorado River below Parker Dam & Relation of discharge to stream stage \\
\hline 9 & 09429490 & Colorado River above Imperial Dam & $\begin{array}{l}\text { Discharge is computed as the sum of discharge at } \\
\text { multiple streamflow-gaging stations }\end{array}$ \\
\hline 10 & 09429500 & Colorado River below Imperial Dam & $\begin{array}{l}\text { Discharge is computed as the sum of discharge at } \\
\text { multiple streamflow-gaging stations }\end{array}$ \\
\hline 11 & 09520500 & Gila River near Dome & Relation of discharge to stream stage \\
\hline 12 & 09522000 & $\begin{array}{l}\text { Colorado River at the northerly international } \\
\text { boundary with Mexico }\end{array}$ & Relation of discharge to stream stage \\
\hline 13 & 09522400 & Mittry Lake Diversion at Imperial Dam & Sparling meter \\
\hline $\begin{array}{l}14 \mathrm{a} \\
14 \mathrm{~b}\end{array}$ & $\begin{array}{r}09522500 \\
---\end{array}$ & $\begin{array}{l}\text { Gila Gravity Main Canal at Imperial Dam: } \\
\text { Stilling-well gage (USGS) } \\
\text { AVM gage (BOR) }\end{array}$ & $\begin{array}{l}\text { Relation of discharge to stream stage } \\
\text { AVMs in open conduits }\end{array}$ \\
\hline $\begin{array}{l}15 \mathrm{a} \\
15 \mathrm{~b}\end{array}$ & $\begin{array}{r}09522700 \\
---\end{array}$ & $\begin{array}{l}\text { Wellton-Mohawk Canal: } \\
\text { Radial-gates gage (USGS) } \\
\text { AVM gage (BOR) }\end{array}$ & $\begin{array}{l}\text { Relation of discharge to forebay and afterbay stage and } \\
\text { gate opening } \\
\text { AVMs in open conduits }\end{array}$ \\
\hline 16 & 09523000 & All-American Canal near Imperial Dam & Relation of discharge to stream stage \\
\hline 17 & 09527500 & All-American Canal below Pilot Knob wasteway & $\begin{array}{l}\text { Relation of discharge to forebay and afterbay stage and } \\
\text { gate opening }\end{array}$ \\
\hline
\end{tabular}

${ }^{1}$ Reservoir content is monitored at the gaging station.

Several constraints had to be considered for selecting and developing the error-estimation methods. The methods had to reflect conditions specific to each streamflow-gaging station for the time period of interest. Several different techniques were used to compute discharge at the streamflow-gaging stations including use of stagedischarge relations, acoustic velocity meters (AVMs), relation of discharge to head and gate openings at artificialcontrol structures, and sparling meters. This variety of streamflow-gaging techniques required that the errorestimation methods be adaptable to accommodate each streamflow-gaging technique. The methods also had to reflect differences in discharge from station to station and from year to year. Although the USGS operates several of the streamflow-gaging stations of interest, other agencies are involved and participate by operating or supplying data for some of the streamflow-gaging stations. These agencies include the BOR, Imperial Irrigation District (IID), and the International Boundary and Water Commission (IBWC). In order for error estimates to be performed in a timely manner, data used in the error analysis must be easily and readily accessible from these agencies, and it must be possible to automate the methods. Further, the costs of estimating the error should be a relatively small portion of the gaging-station operational cost so that future estimates of error are financially feasible. 
In addition to the constraints on the methods of estimating error, certain conditions were present that limit the ability to estimate error. Statistical methods are not used for computing discharge by the agencies operating the streamflow-gaging stations in this study. Rather, personal judgement using knowledge of the hydrologic system and conditions during discharge measurements are preferred over stringent mathematical procedures (Rantz, 1982b). Because statistical methods are not used to compute discharge, it is not possible to directly apply statistical theory to quantify the actual uncertainty in the computed discharge. Therefore, the procedures presented here attempt to capture and quantify the uncertainty from the major sources of uncertainty that affect discharge and reservoir-content data through the practiced computation procedures.

Finally, one of the fundamental difficulties of determining the uncertainty in computed discharge volumes is that there is no 'gold standard' available for comparison. That is, for some measurements, such as mass, there is a standard available, such as a gold weight, that is known to be true and without error, and by which one can test instrumentation and determine measurement errors. In the field of streamflow gaging, there is no such gold standard available.

\section{Purpose and Scope}

This report documents the methods used to determine both standard errors of and variance of estimate of the annual discharge and change in reservoir content from 1995 through 1999, and presents the results of the application of these methods for stations listed in table 1. Annual data in this report are based on the calendar year. In addition, this report documents streamflow-gaging strategies that would reduce the variance of estimate of the annual discharge or improve the error estimates for streamflow-gaging stations.

\section{Acknowledgments}

The author would like to thank the staffs from the Central Arizona Water Conservation District, the Imperial Irrigation District, the International Boundary and Water Commission Yuma field office, the Metropolitan Water District of Southern California, the Bureau of Reclamation Blythe field office, and the U.S. Geological Survey Yuma field office who provided streamflow-gaging data and discussions about methods used to gage streamflow. In particular, the author thanks John Weiss of the Bureau of Reclamation Blythe field office and Bill Roberts and Howard McCormack of the U.S. Geological Survey Yuma field office for discussions and field observation of the streamflow-gaging methods and equipment used by each agency. Special thanks go to Dr. Marshall Moss, U.S. Geological Survey retired hydrologist, and Dr. Donald Davis, professor of hydrology at the University of Arizona, for the many valuable technical discussions regarding error analysis and statistics.

\section{STREAMFLOW-GAGING TECHNIQUES}

The techniques of computing the annual discharge at streamflow-gaging stations in this study generally involve continuously monitoring a correlative variable as a surrogate for discharge, such as stage, and then applying a discharge rating to the correlative data to compute a continuous record of discharge (table 2). The annual discharge is computed by integrating the discharge record over time.

When stations are established, a discharge rating is constructed from several measurements of discharge and the correlative variables. Discharge measurements typically are made by using vertical-axis current meters, except at two stations operated by the BOR, which use broadband acoustic doppler current profile (ADCP) meters. Graphical methods typically are used to determine the discharge-rating equation coefficients, and in many cases the discharge rating takes the form of a rating curve rather than a rating equation (Rantz, 1982b). In this report, "measured discharge" refers to discharge measured by using vertical-axis current meters or broadband ADCPs, and "computed discharge" refers to discharge computed from a discharge-rating equation or discharge-rating curve. 
Table 2. Stream-gaging techniques and generalized rating equations used to compute discharge at streamflow-gaging stations

$\left[q_{r}\right.$, rated discharge; $c_{0}, c_{1}$, and $c_{2}$, constants; $h$, stream stage; $h_{g}$, gate opening; $h_{1}$, forebay stage; $h_{2}$, afterbay stage; $v_{i}$, acoustic velocity meter index velocity; $s_{1}$, sparling meter volume reading at time $t_{1} ; s_{2}$, sparling meter volume reading at time $\left.t_{2}\right]$

\begin{tabular}{lc}
\hline \multicolumn{1}{c}{ Gaging technique } & \multicolumn{1}{c}{ General rating equation } \\
\hline Relation of discharge to stream stage & $q_{r}=c_{0}\left(h+c_{1}\right)^{c_{2}}$ \\
$\begin{array}{l}\text { Relation of discharge to gate opening and forebay } \\
\text { and afterbay stage }\end{array}$ & $q_{r}=c_{0} \times h_{g} \times\left(h_{1}-h_{2}\right)^{c_{2}}$ \\
Acoustic velocity meters in open channels & $q_{r}=c_{0} \times\left(h+c_{1}\right)^{c_{2}} \times v_{i}$ \\
& $q_{r}=c_{0} \times\left(\frac{s_{2}-s_{1}}{t_{2}-t_{1}}\right)$ \\
Sparling meter & $q_{\text {sum }}=q_{\text {station }}+q_{\text {station }}+\ldots q_{\text {station }}$ \\
\hline
\end{tabular}

After the discharge rating is developed, the discharge-rating is verified by visiting streamflow-gaging stations on a routine basis and measuring discharge and the correlative variables. For some streamflow-gaging stations, the measurements indicate that the relation between discharge and the correlative variables is steady state and, therefore, the discharge rating never needs temporal adjustments. For most streamflow-gaging stations, however, the relation between discharge and the correlative variable is not steady state and, over time, may be changed by physical and biological processes in the stream, such as channel aggradation or degradation, vegetation growth, or by changes in the gaging equipment, such as increased friction in a sparling meter or drift in instruments that measure gate openings. If the discharge measurement indicates that the relation between discharge and the correlative variables has changed, a shift is applied to the discharge rating to make the discharge rating agree with the discharge measurement (fig. 3). Discharge-rating shifts typically are not consistent from discharge measurement to discharge measurement; therefore, the discharge-rating shifts usually are interpolated for periods between the discharge measurements. If the relation between discharge and the correlative variable has changed substantially, a new discharge rating is developed.

For many streamflow-gaging stations, seasonal and long-term processes act on the channel or artificial control and result in a non-steady state relation between discharge and the correlative variable. The non-steady state relation is evident by seasonal or long-term trends in the discharge-rating shifts. Seasonal patterns in dischargerating shifts may occur because of algal or aquatic plant growth on the control, or because of high or low flows that tend to reconfigure the channel bed. Long-term trends in the discharge-rating shifts may occur because of natural or anthropogenic activities upstream. For instance, Moss and Gilroy (1980) found that impoundment of sediments behind Davis Dam resulted in the degradation of the channel below the dam and caused a long-term trend in the discharge-rating shifts for the Colorado River below Davis Dam.

In addition to the seasonal or long-term processes, there also are random processes that affect the discharge rating at shorter time scales. In the case of discharge ratings for open channels, these generally are processes that affect the control, such as scour and fill. While these processes are random, their effects on the discharge-rating shifts are serially correlated; that is, knowledge of the discharge-rating shift on one day reduces the uncertainty in the estimated discharge-rating shift for the following day. Consider, for example, that the random physical process is sediment transport. A random amount of sediment deposited to the streambed on one day will affect the discharge-rating shift for that day. That deposition of sediment also will have effects on the following day; however, additional sediment transport on the following day will have an effect on the discharge-rating shift for that following day. By applying a shift to the discharge rating on the basis of periodic discharge measurements, the discharge rating is corrected over time for the effects of the random, seasonal, and long-term processes that affect the relation between discharge and the correlative variable. 


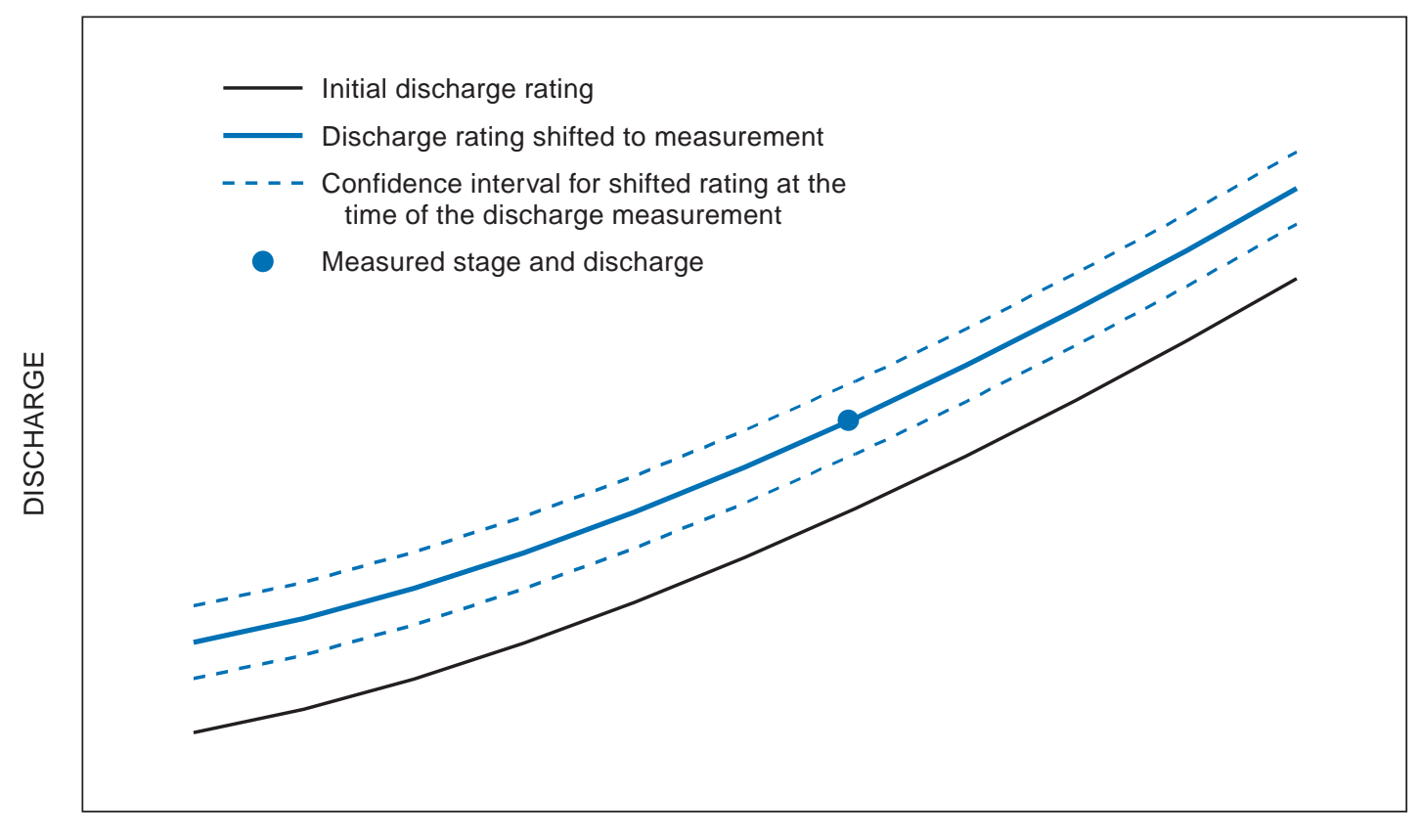

GAGE HEIGHT, IN FEET

Figure 3. Shifting the discharge rating on the basis of a discharge measurement.

\section{PREVIOUS ERROR-ESTIMATION STUDIES}

Several studies have investigated the uncertainty in discharge measurements made with vertical-axis current meters and the uncertainty in computed discharges (instantaneous discharge and the annual discharge). Although studies have provided methods of determining errors, none of the methods have been used in a standard manner to report errors alongside the discharge data published in annual data reports for Arizona (such as Tadayon and others, 2000).

Carter and Anderson (1963) developed methods of determining the standard error of discharge measurements made with vertical-axis current meters. This method was expanded by Sauer and Meyer (1992). Estimates of the standard error of discharge measurements are used, along with other information, to determine estimates of the standard error of computed discharges (Burkham and Dawdy, 1968; Moss and Gilroy, 1980; Wahlin and others, 1997). Burkham and Dawdy (1968) put forth the assumption that the uncertainty in the discharge-rating shift is the major source of uncertainty in computed discharges. Moss and Gilroy (1980) also used this assumption and developed a method for estimating the standard error of the annual discharge that considers the serial correlation of errors in the discharge-rating shifts. Neglecting this serial correlation may result in an underestimated uncertainty in the annual discharge (Moss and Gilroy, 1980). The estimates of the standard error of the annual discharge presented in this study were determined by using a modified version of the Moss and Gilroy (1980) method. The modifications include use of either the Sauer and Meyer (1992) method or semivariograms to estimate the uncertainty in discharge measurements, rather than the Carter and Anderson (1963) method.

Three other studies investigated the uncertainty in computed discharges for streamflow-gaging stations in the study area. Owen-Joyce and Raymond (1996, p. 82) assessed the general sources of uncertainty in the components of the LCRAS water balance. In this assessment, the uncertainty in the annual discharge was coarsely estimated for several stations listed in table 1 on the basis of qualitative estimates of the uncertainty in daily discharge values. 
Madigan and Weiss (1996) discuss the calibration and uncertainty of data from AVMs that were installed and operated by the BOR at three stations in this study: Gila Gravity Main Canal at Imperial Dam (site 14b, figs. 1 and 2), Wellton-Mohawk Canal (site 15b, figs. 1 and 2), and All American Canal near Imperial Dam (near site 16, figs. 1 and 2). Wahlin and others (1997) determined the standard error of the annual discharge for several streamflow-gaging stations in the Imperial Valley, including All-American Canal below Pilot Knob wasteway (site 17, figs. 1 and 2). Their method determined the standard error of computed discharge data by using a rootmean-square method to combine partial errors from various sources of uncertainty. The methods used in these studies to determine the standard error of computed discharge data were not used in this study because they did not account for the serial correlation of the discharge-rating shift.

\section{Discharge measurements}

Carter and Anderson (1963) established an empirical method for estimating the standard error of discharge measurements made with vertical-axis current meters, such as the Price-AA and Price-pygmy meters. The standard error was determined by using the root-mean-square method to combine partial errors that result from the type of current meter used, velocity fluctuations, deviations from the assumed vertical-velocity distribution, and the number of observation stations in the measuring section.

Sauer and Meyer (1992) found the uncertainty in discharge measurements made with vertical-axis current meters results from errors in measurements of width, depth, and velocity, and in computational procedures. The method essentially expanded Carter and Anderson's list of partial errors that contribute to the uncertainty in a discharge measurement. The standard error of a discharge measurement is determined by using the root-meansquare method to combine partial errors

$$
S_{q_{m_{i}}}=\sqrt{\left(\frac{S_{d}^{2}+S_{t}^{2}}{m}\right)+S_{i}^{2}+S_{s}^{2}+S_{h d v}^{2}+S_{o f}^{2}+S_{s b}^{2}+S_{s d}^{2}+S_{s v}^{2}},
$$

where $m$ is the number of sections, and $S_{q_{m_{i}}}$ is the standard error of discharge measurement $i$, which is composed of partial random errors in:

$S_{d}$, depth measurements;

$S_{t}$, pulsation of velocity;

$S_{i}$, instrumentation (current meter);

$S_{S}$, deviations from the vertical velocity distribution;

$S_{h d,}$ horizontal distribution of depth and velocity;

$S_{o f}, \quad$ oblique flow angles;

and from partial bias errors in:

$S_{s b}$, width measurements;

$S_{s d}$, depth measurements; and

$S_{S v}$, velocity measurements. 
The magnitude of the partial errors is determined from characteristics of the discharge measurement such as channel width, mean channel depth, mean velocity, number of sections, average observation time for each section, meter type, presence of horizontal or vertical angles, method of meter suspension (rod, bridge, cableway), and channel-bed conditions (stable/unstable, soft/firm). Sources of uncertainty such as moderate to large changes in stage, boundary effects, ice, flow obstructions, wind, and improper equipment usage are not considered by this method.

Sauer and Meyer also developed a computer program to facilitate error computations. Most of the required input is recorded and stored digitally as part of the standard USGS procedures for measuring and computing discharge. The program output includes an estimate of the percent error for individual discharge measurement $i$, which is computed as:

$$
\alpha_{i}=\frac{S_{q_{m_{i}}}}{q_{m_{i}}} \times 100,
$$

where

$$
\begin{aligned}
\alpha_{i} & =\text { the percent error for individual discharge measurement } i \\
q_{m_{i}} & =\text { the discharge for measurement } i \text {, and } \\
S_{q_{m_{i}}} & =\text { the standard error of discharge measurement } i .
\end{aligned}
$$

Sauer and Meyer (1992) found that for normal measuring conditions, the standard error of discharge measurements range from about 3 to 6 percent. The standard errors, however, could be as small as about 2 percent under ideal conditions or as large as about 20 percent when conditions are poor and shortcut methods are used (such as those methods used during flood measurements).

The Sauer and Meyer method, like the Carter and Anderson method, provides only a coarse estimate of the uncertainty in a discharge measurement. This is because not all sources of uncertainty are considered and because the magnitude of partial errors are estimated on the basis of results from empirical laboratory and field studies for other stream locations rather than the exact conditions for the discharge measurement under consideration.

\section{Computed discharges}

Burkham and Dawdy (1968) established a method for determining standard error of computed discharge data for two streamflow-gaging stations on the Gila River in central Arizona. They assumed that the major source of the uncertainty in computed discharges was from the uncertainty in the discharge-rating shift. They devised a split sampling procedure to estimate the standard error of computed discharges by comparing computed discharges with measured discharges. In the split sample procedure, a small fraction of the discharge measurements were put into an analysis group that was used to establish a discharge rating, and a continuous record of discharge was computed by applying the discharge rating to a continuous record of stage. The remaining discharge measurements formed the control group. The standard error of the difference between measured and computed discharge was determined as

$$
S_{m-c}=\sqrt{\frac{1}{n} \times \sum_{i=1}^{n}\left(q_{m_{i}}-q_{r_{i}}\right)^{2}}
$$


where

$$
\begin{aligned}
S_{m-c} & =\text { the standard error of the difference between measured and computed discharge; } \\
n & =\text { the number of discharge measurements; } \\
q_{m_{i}} & =\text { discharge for measurement } i \text {, and } \\
q_{r_{i}} & =\text { computed discharge at the time discharge measurement } i \text { was made. }
\end{aligned}
$$

$S_{m-c}$ is not the standard error of computed discharges because the measured discharge used in the comparison contains uncertainty. The standard error of the computed discharge can be determined by accounting for this measurement error

where

$$
S_{c}=\sqrt{S_{m-c}^{2}-\frac{1}{n} \sum_{i=1}^{n} S_{q_{m_{i}}}^{2}},
$$

$$
\begin{aligned}
S_{c} & =\text { standard error of a computed instantaneous discharge, and } \\
S_{q_{m_{i}}} & =\begin{array}{l}
\text { standard error of the discharge measurement } i \text { as determined by the Carter and Anderson } \\
\text { method (1963). }
\end{array}
\end{aligned}
$$

In the next stage, the analysis group was increased by adding some of the measurements from the control group, and the record computation and error assessment were repeated. This allowed Burkham and Dawdy to develop a relation between the number of discharge measurements used in the analysis group and the standard error of the computed discharge record.

Burkham and Dawdy (1968) noted that the uncertainty in the annual discharge should be less than that for computed instantaneous discharge data because of the compensating effects of errors. For example, errors in the discharge measurement may result in computed discharges that are larger than the true discharges for one period between discharge measurements. Then for another period between discharge measurements, errors in the discharge measurements may result in computed discharges that are smaller than the true discharge. For an extended period with many such periods between discharge measurements, such as a calendar year, these errors in computed discharge for the different periods between discharge measurements will tend to cancel each other, resulting in an error in the annual discharge that is smaller than the error in any one period between discharge measurements. Burkham and Dawdy estimated the standard error of the annual discharge by dividing the standard error of a computed discharge value by the number of discharge measurements made during the year. Because of the large number of discharge measurements that are required, the split-sample technique can be cost-prohibitive for studies such as this one that are investigating many streamflow-gaging stations. In addition, the technique neglects the serial correlation of errors in the computed discharge record.

Moss and Gilroy (1980) performed an error analysis study that included several of the stations used in this study. The purpose of their study was to optimize the frequency of discharge measurement for streamflow-gaging stations in the lower Colorado River network by minimizing the variance of estimate of the streamflow data for the network under certain cost constraints. Moss and Gilroy's approach involved determining the variance of estimate of the annual discharge for each streamflow-gaging station as a function of the frequency of the discharge measurements; the less time between discharge measurements, the more precise the annual discharge. With functions relating error and cost to discharge measurement frequency for all streamflow-gaging stations in the network, the optimal strategy was found for monitoring discharge at streamflow-gaging stations within the network. The error-estimation methods that were developed and demonstrated for the lower Colorado River streamflow-gaging stations were later used in an analysis of the national USGS streamflow-gaging station network (Fontaine and others, 1984). 
Like the Burkham and Dowdy method (1968), the Moss and Gilroy method assumes that the uncertainty in computed discharges originates from the uncertainty in the discharge-rating shift. In the Moss and Gilroy method, however, the uncertainty in the discharge-rating shift is caused by measurement error and process error. Process error is caused by physical processes, such as sediment transport, that change the relation between discharge and the correlative variables. It is assumed that these processes cause the discharge-rating shift to vary in time as a random continuous first-order Markovian process (fig. 4). When a discharge measurement is made, the dischargerating shift can be estimated, which is equivalent to estimating the state of the Markovian process. The true state of the Markovian process, or the true discharge-rating shift, however, cannot be attained because the discharge measurement contains measurement error (fig. 4). As time progresses from the discharge measurement, physical processes will affect the relation between discharge and the correlative variables, thereby changing the state of the Markovian process. The periodic measurement of discharge tracks the state of the Markovian process over time. For periods between discharge measurements, the state of the Markovian process, or the discharge-rating shift, is estimated by interpolation. Because the Markovian process is serially correlated, knowledge of the state of the process at the time of the discharge measurement will reduce the uncertainty in the estimate of the state of the process for times adjacent to the discharge measurement. As time advances from the latest discharge measurement, the uncertainty in the estimate of the state of the process and of the discharge-rating shift will increase. Discharge measurements provide information about the state of the process for times both before and after the time of the discharge measurement; therefore, the increase in uncertainty occurs both forwards and backwards in time from a discharge measurement. Because the discharge-rating shift is interpolated between measurements, the uncertainty is at a maximum midway between two measurements. The uncertainty in the discharge-rating shift results in an uncertainty in the computed instantaneous discharge, which will have the same temporal pattern in uncertainty (fig. 5A). Given the same time interval between measurements, the uncertainty in computed instantaneous discharge during the period between measurements is larger for a larger measurement variance (fig. 5B), a larger process variance (fig. 5C), or less serial correlation of state of the process (fig. 5D). The uncertainty of computed instantaneous discharge decreases if measurements are made more frequently because the process error is serially correlated (fig. 5E).

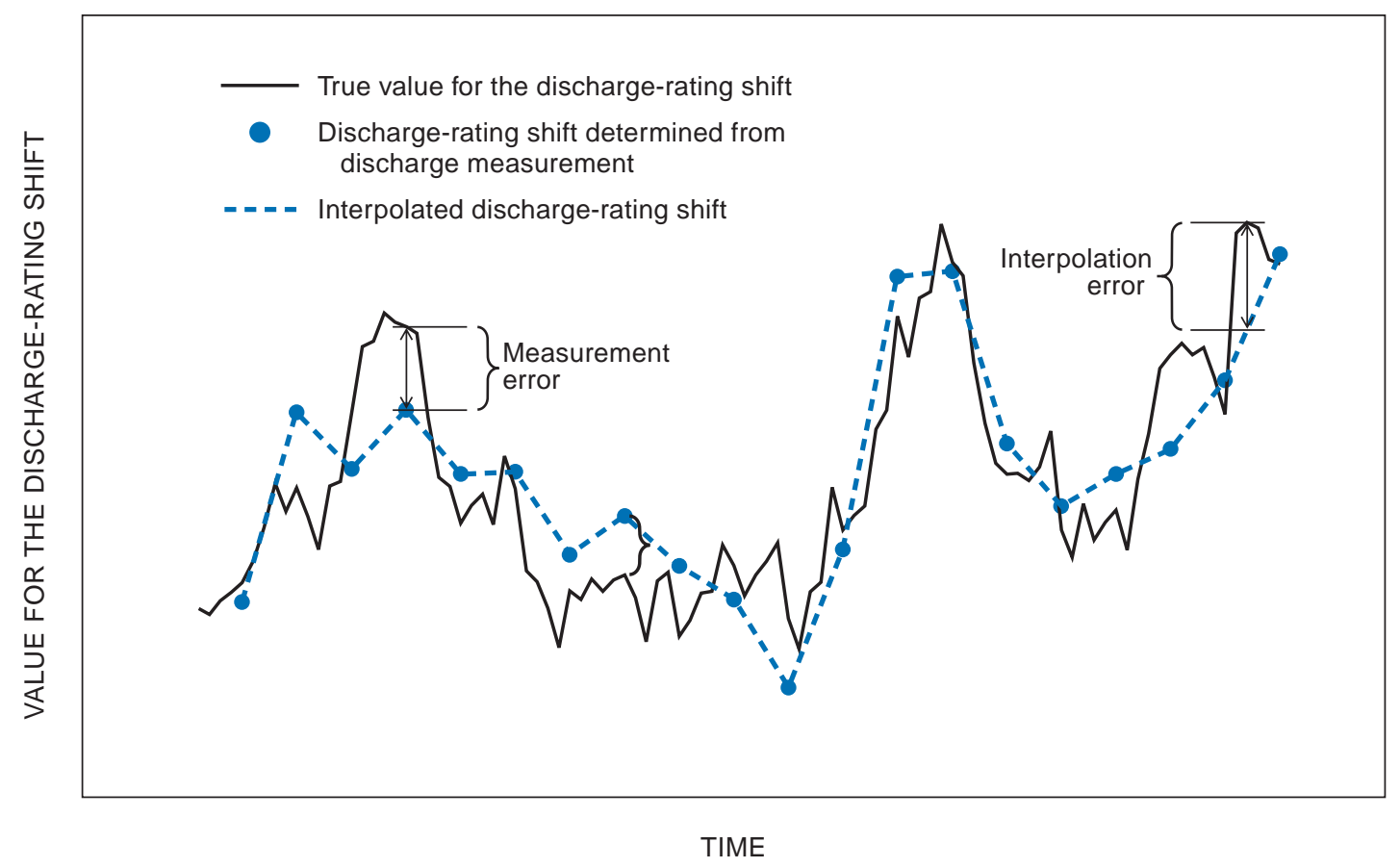

Figure 4. Conceptual model for uncertainty in the discharge-rating shift. 

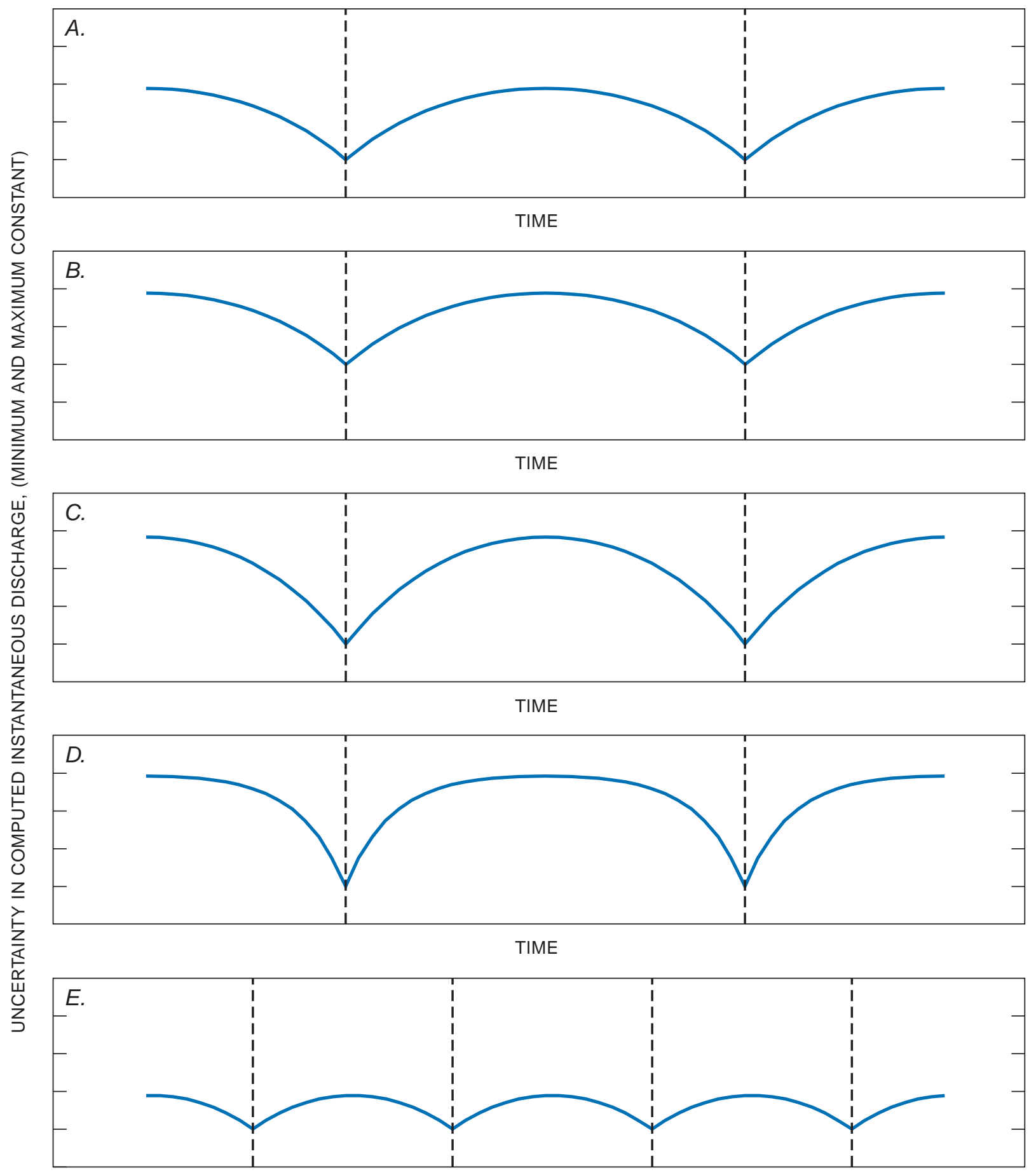

TIME

Figure 5. Conceptual model for uncertainty in computed instantaneous discharge as affected by measurement variance, variance of the process affecting the discharge rating, and serial correlation of that process. Vertical dashed lines indicate time of discharge measurement collection. $A$, Base conditions for measurement variance, process variance, and serial correlation. $B$, Larger measurement variance, same process variance and serial correlation as base conditions. $C$, Larger process variance, same measurement variance and serial correlation as base conditions. $D$, Less serial correlation, same measurement variance and process variance as base conditions. $E$, Shorter time intervals between discharge measurements, same measurement variance, process variance, and serial correlation as base conditions. 
The Moss and Gilroy method uses Kalman-filter theory to determine the uncertainty of computed instantaneous discharge and annual discharge. Kalman filtering is a time series smoothing technique that provides a minimum variance estimate for the state of a Markovian process over time on the basis of periodic measurements that contain measurement error. This is analogous to determining the discharge- rating shift over time on the basis of information from periodic discharge measurements. Kalman-filter theory also provides a method to determine the uncertainty in the estimated values of the random process, or for the stream-gaging analogy, it provides a method to estimate the uncertainty in the shift. The Moss and Gilroy method determines the standard error of computed instantaneous discharge and annual discharge on the basis of Kalman-filter theory and estimates of (1) measurement variance for the discharge measurements, (2) variance of the Markovian process, (3) the serial correlation of the Markovian process, and (4) the frequency of discharge measurements. The mathematical details of the Kalman-filter theory and its use to estimate the uncertainty in computed instantaneous discharge and annual discharge are further discussed in Moss and Gilroy (1980).

The Markovian process is modeled in units of discharge rather than in units of stage. Although this represents a deviation from the methods actually used to compute discharge, it allows for estimation errors of the state of the process (or the discharge-rating shift) to be computed in terms of discharge, which can be integrated over time to provide an estimate for the uncertainty in a discharge volume. Another benefit of modeling discharge-rating shifts in units of discharge is that it allows analysts to use the same general model at several stations that may be gaged by using a variety of methods. That is, all types of streamflow-gaging stations measuring discharge have ratings that can be shifted in units of discharge, which precludes the need for several error-estimation methods.

\section{METHODS OF ESTIMATING STANDARD ERRORS OF THE ANNUAL DISCHARGE}

The method of determining the standard error of the annual discharge established by Moss and Gilroy (1980) was selected as the method to be used in this study. This method was chosen over other methods mentioned in this report because it accounts for the effects of serial correlation of the discharge-rating shift error and the others do not. The method of estimating the measurement variance was modified as part of this study because the method used by Moss and Gilroy (1980) resulted in an overestimate of measurement variance at some streamflow-gaging stations. Details of estimating the variance of estimate of the annual discharge by using the modified Moss and Gilroy method are discussed in this section and illustrated using data from Colorado River at the northerly international boundary with Mexico (NIB; site 12, figs. 1 and 2). This station was selected because of the dynamic nature of the relation between stage and discharge and the high frequency of discharge measurements. A study period of 1995-99 was selected because it was recent and also because the streamflow was variable at many stations during that period and allowed for detection of problems and limitations of the method.

The Moss and Gilroy method requires estimates of measurement variance, $S_{m}{ }^{2}$, process variance, $S_{p r}{ }^{2}$, and the one-day serial correlation-coefficient, $\rho$, for residuals from an unbiased discharge rating. The Kalman-filter theory and the methods of estimating $\rho$ require second-order stationarity of the residuals from the discharge rating; that is, the discharge-rating residuals must have a mean of zero and constant variance over time. Most of the relations between discharge and the correlative variables at streamflow-gaging stations in this study were not steady state, and, therefore, residuals from the discharge ratings used in practice contained seasonal and long-term trends. The presence of these trends indicates the residuals are non-stationarity and precluded use of the discharge ratings actually used in practice. As a result, it was necessary to develop temporally unbiased discharge ratings by using nonlinear regression, which was performed by using computer software (MathSoft, 2000a).

The first step in developing temporally unbiased discharge ratings for a streamflow-gaging station was to identify the time period that the discharge rating(s) was valid and the discharge measurements to use for each rating. This was accomplished by developing an initial discharge-rating equation on the basis of all discharge measurements made between 1995 and 1999 (fig. 6). For stations with infrequent discharge measurements, and therefore a small number of discharge measurements, additional discharge measurements made prior to 1995 were used to develop this initial discharge rating. The time series of the residuals from the initial rating was then plotted and visually inspected for changes in the slope of the residuals over time, or for jumps in the series (fig. 7). 


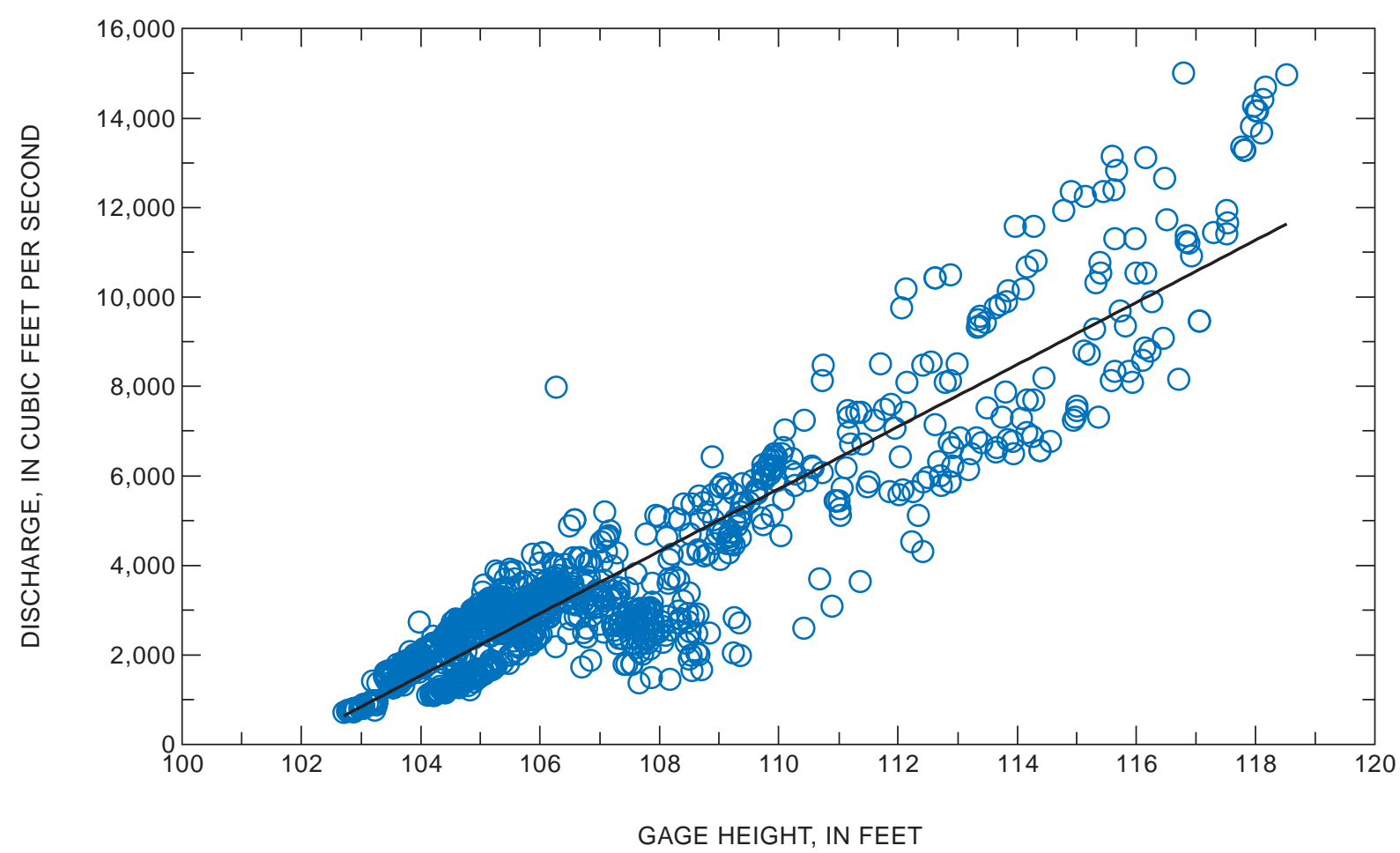

Figure 6. Stage-discharge rating for Colorado River at the northerly international boundary with Mexico, January 1, 1995, to December 31, 1999. Black line is least squares linear fit.

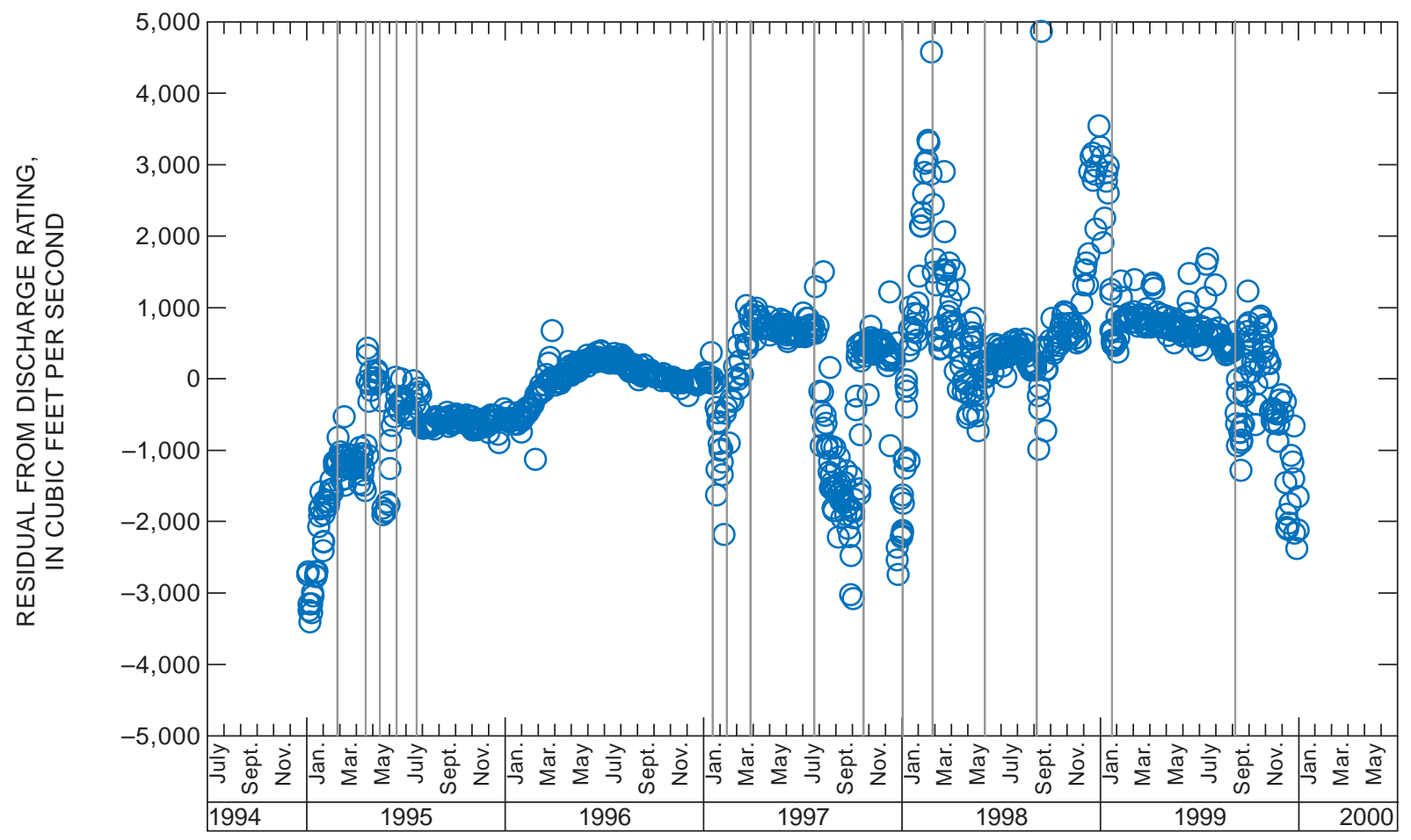

Figure 7. Residuals from the stage-discharge rating (fig. 6) for Colorado River at the northerly international boundary with Mexico, January 1, 1995, to December 31, 1999. Vertical lines indicate boundary between discharge-rating periods. 
These features in the time series of residuals indicated disruptions and changes between the relation of discharge to stage (or other correlative variables) and indicated the boundaries between discharge-rating periods. These disruptions usually resulted from physical events perturbing the channel such as scour and fill during a flood, vegetation removal from canals, stream-channel dredging, or from other causes such as the replacement or renovation of gaging equipment. The periods for the discharge ratings that were actually used by field office staff to compute discharge were also used as guides to determine the valid periods for the discharge ratings developed as part of the error analysis.

After the different discharge-rating periods had been determined, individual discharge ratings were developed for each discharge-rating period. Initially, a non time-dependent discharge rating was developed (fig. 8), followed by inspection of the discharge-rating residuals for seasonal and long-term trends (fig. 9). Long-term and seasonal trends in the residuals were removed by developing a time-dependent discharge rating that included a linear function and periodic function that adjusted the gage height on the basis of time. For example, the discharge-rating equation for the Colorado River at the NIB (site 12, figs. 1 and 2), from July 28, 1995, to January 16, 1997, was

$$
q_{r}=719.3(h-103.35+0.98(t-1995)-0.361 \cos (2 \pi t)+0.134 \sin (2 \pi t))
$$

where

$$
\begin{aligned}
q_{r} & =\text { rated discharge; } \\
h & =\text { gage height; and } \\
t & =\text { time, in decimal years. }
\end{aligned}
$$

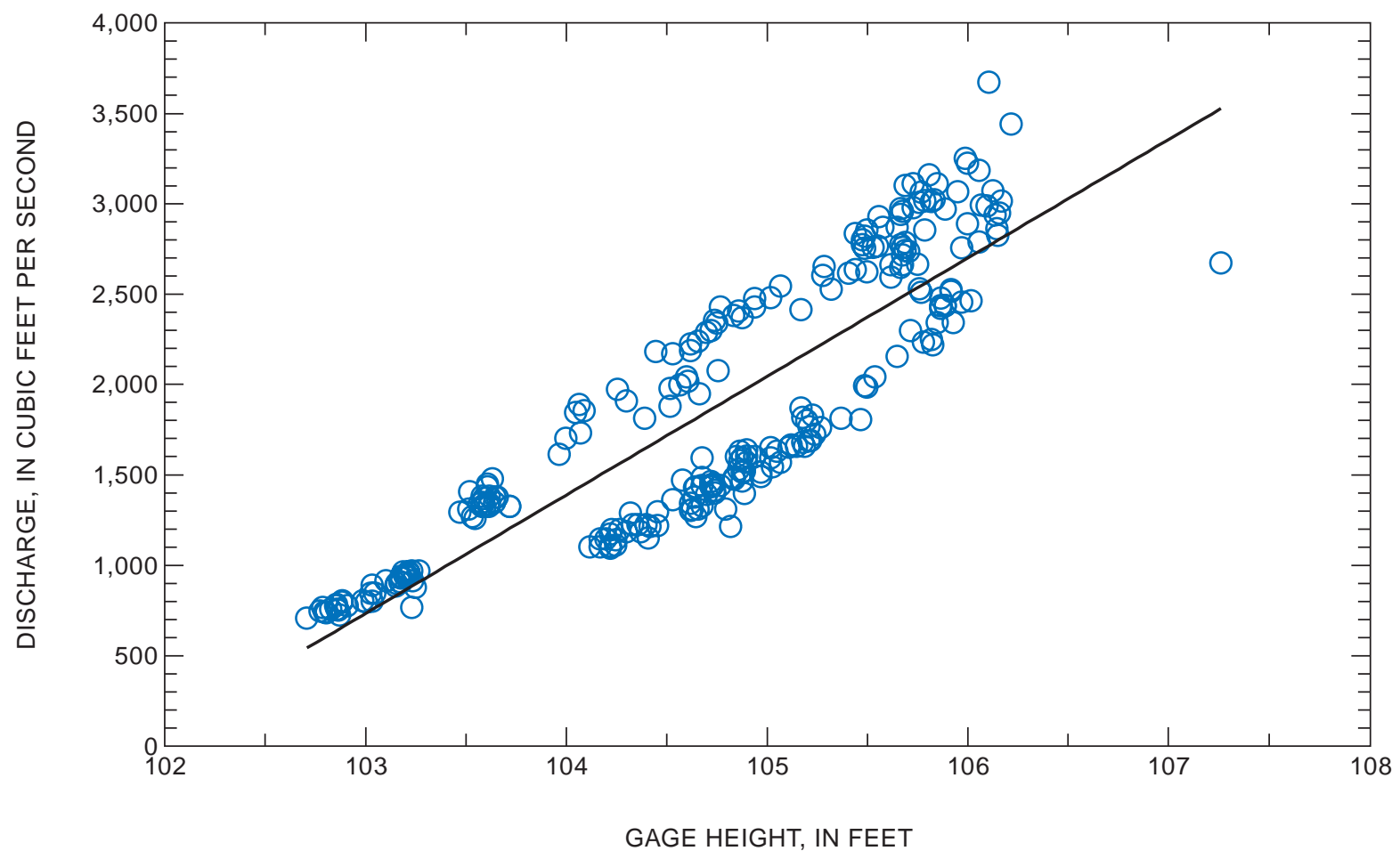

Figure 8. Non-time-dependent stage-discharge rating for Colorado River at the northerly international boundary with Mexico, July 28, 1995, to January 16, 1997. Black line is least squares linear fit. 


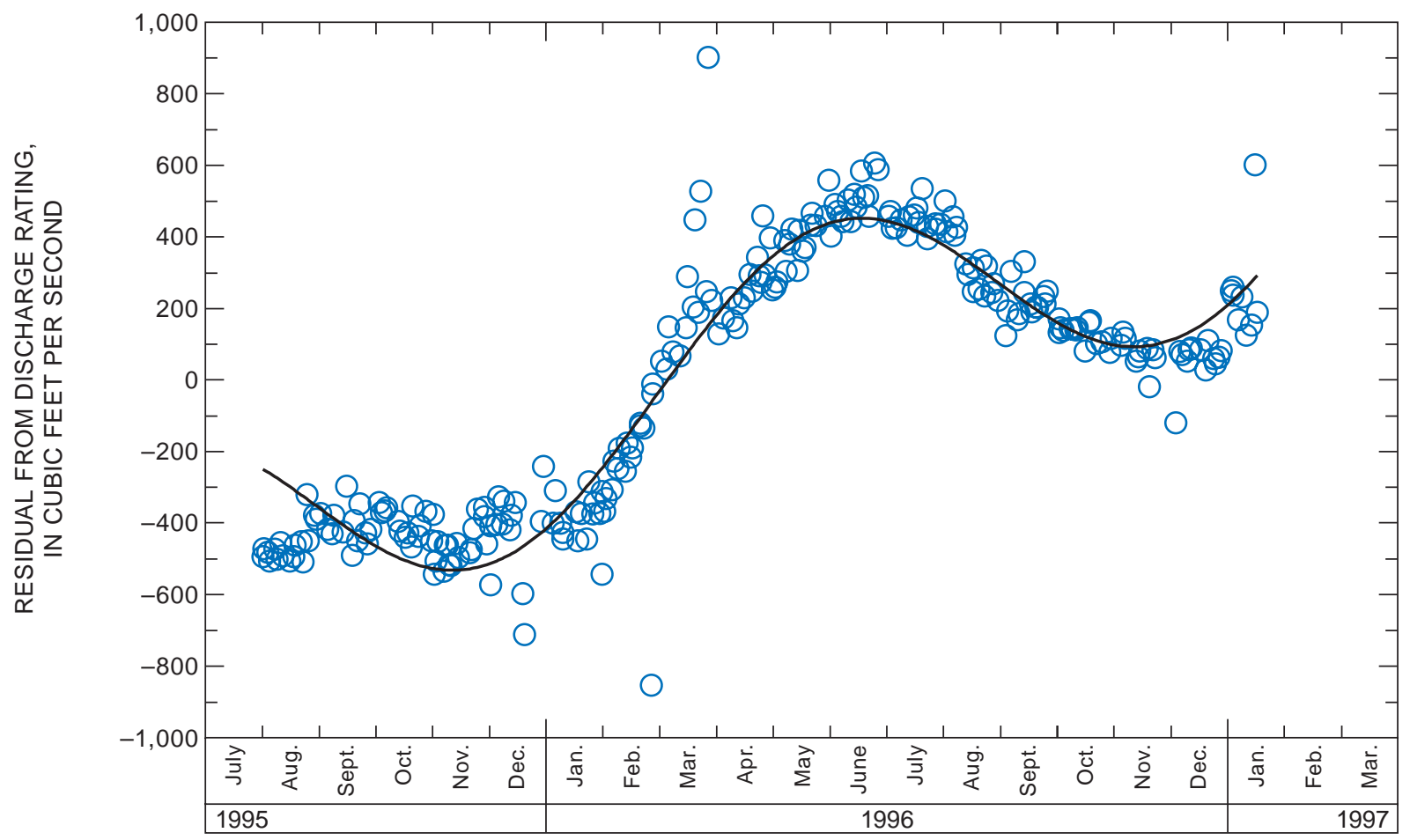

Figure 9. Residuals from the non-time-dependent stage-discharge rating for Colorado River at the northerly international boundary with Mexico, July 28, 1995, to January 16, 1997. Black line is least squares fit of linear and seasonal temporal trend.

The last three terms on the right side of the equation remove the temporal trends in the relation between stage and discharge. The relation between stage and discharge can be observed without the confounding temporal effects by adjusting gage heights on the basis of the last three terms of the equation (fig. 10). With the long-term and seasonal temporal effects included in the time-dependent discharge rating, it was assumed that the discharge-rating residuals (from equation 6) were second-order stationary (fig. 11).

By using the temporally unbiased discharge-rating residuals and an estimate of the measurement variance, the process variance and one-day serial correlation coefficient can be determined. Moss and Gilroy (1980) estimated measurement variance by using a single value for the percent error for all discharge measurements made at a given station:

where

$$
S_{m}^{2}=\frac{1}{n} \sum_{i=1}^{n}\left(\frac{\alpha}{100} \times q_{m_{i}}\right)^{2},
$$

$$
\begin{aligned}
S_{m}^{2} & =\text { measurement variance; } \\
n & =\text { number of discharge measurements; } \\
a & =\text { percent error for discharge measurements; and } \\
q_{m_{i}} & =\text { measured discharge for measurement } i .
\end{aligned}
$$




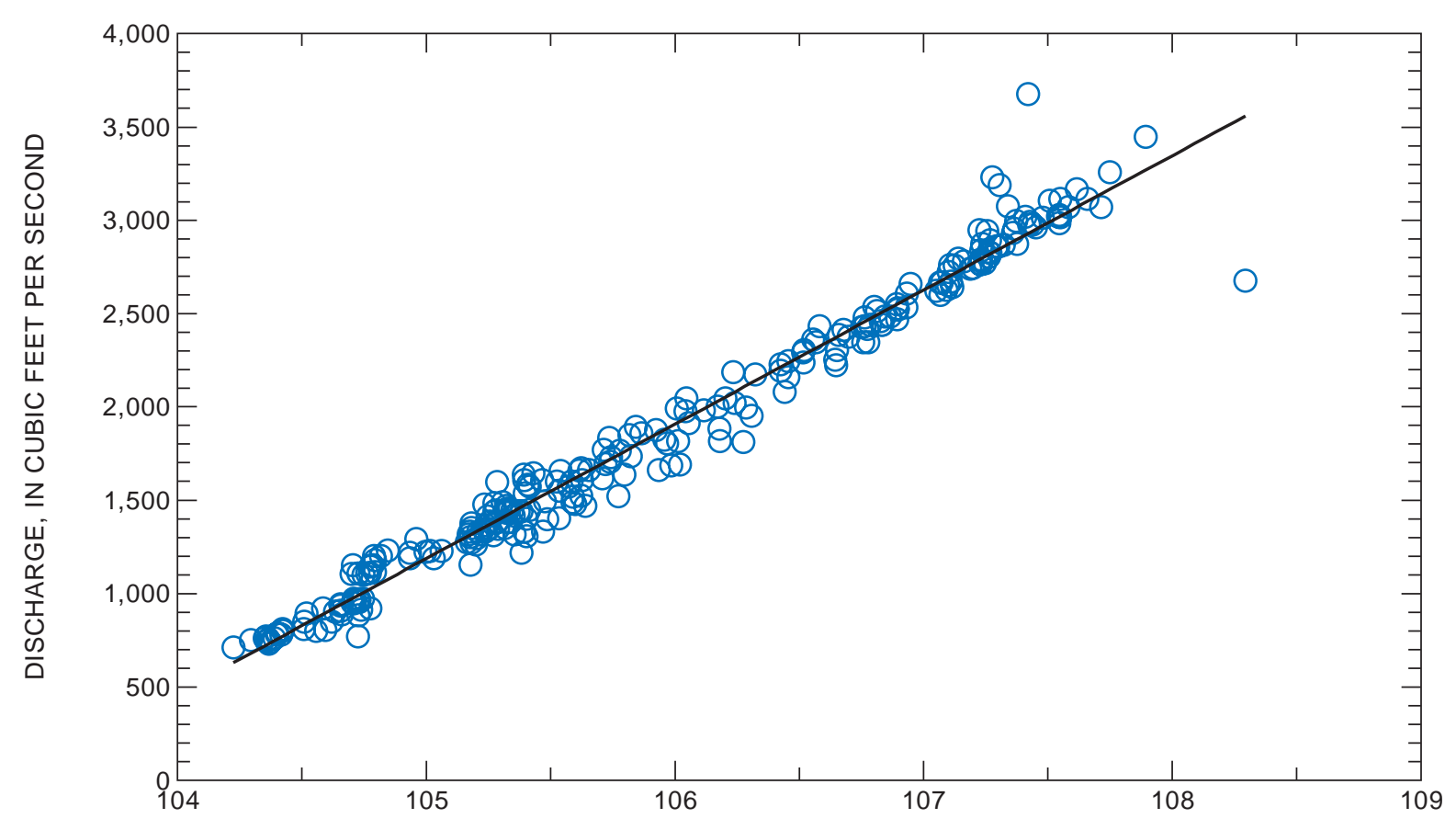

TIME ADJUSTED GAGE HEIGHT, IN FEET

Figure 10. Relation between discharge and time-adjusted gage height for Colorado River at the northerly international boundary with Mexico, July 28, 1995, to January 16, 1997. Black line is least squares linear fit.

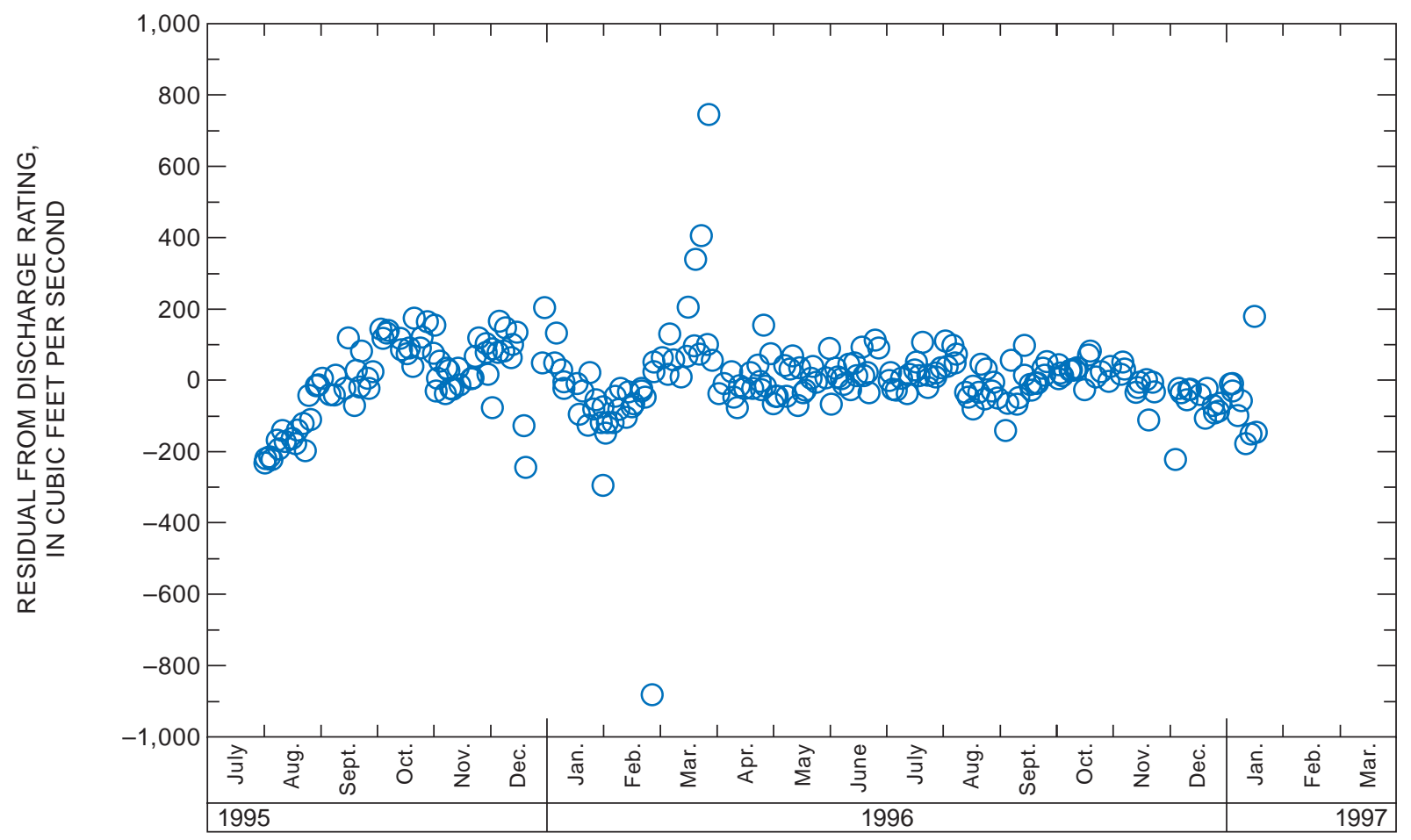

Figure 11. Residuals from time-dependent stage-discharge rating for Colorado River at the northerly international boundary with Mexico, July 28, 1995, to January 16, 1997. 
The percent error for the discharge measurements, $\alpha$, was determined by using the methods described by Carter and Anderson (1963). In this study, the empirical estimates of measurement error were determined by using the Sauer and Meyer (1992) method rather than the Carter and Anderson (1963) method because their more recent method accounts for additional sources of error and because the method was automated to provide error estimates for individual measurements:

where

$$
S_{m}^{2}=\frac{1}{n} \sum_{i=1}^{n}\left(\frac{\alpha_{i}}{100} \times q_{m_{i}}\right)^{2},
$$

$$
\alpha_{i}=\text { the percent error for discharge measurement } i \text {. }
$$

By using an estimate of the measurement variance and the variance of the discharge-rating residuals, the process variance was determined from the following relation (Moss and Gilroy, 1980) which assumes that measurement errors are not temporally related:

$$
S_{z}^{2}=S_{m}^{2}+S_{p r}^{2}
$$

where

$$
\begin{aligned}
S_{z}^{2} & =\text { variance of the discharge-rating residuals, and } \\
S_{p r}^{2} & =\text { process variance. }
\end{aligned}
$$

The Moss and Gilroy method estimates the one-day serial-correlation coefficient, $\rho$, of the discharge-rating residuals on the basis of their covariance. The covariance of the discharge-rating residuals that are $\Delta$ days apart is:

$$
C(\Delta)=\frac{1}{|n(\Delta)|}{ }_{n(\Delta)} \sum\left(z_{i}-\bar{z}\right) \times\left(z_{j}-\bar{z}\right),
$$

where

$n(\Delta)=$ the set of all pairs of residuals that are $\Delta$ days apart;

$|n(\Delta)|=$ the number of pairs in this set;

$C(\Delta)=$ covariance of discharge-rating residuals $\Delta$ days apart;

$z_{i}, z_{j}=$ the value of the discharge-rating residuals for measurements $i$ and $j$ that are $\Delta$ days apart; and

$\bar{z}=$ the average discharge-rating residual.

The covariance plotted as a function of $\Delta$ forms an empirical covariogram. The one-day serial-correlation coefficient can be determined by modeling the empirical covariogram as an exponential function

$$
C(\Delta)=S_{p r}^{2} \times \rho^{\Delta}
$$


where

$$
\rho=\text { the one-day serial-correlation coefficient for the discharge-rating residuals. }
$$

Moss and Gilroy (1980) modeled the covariogram to determine $S_{p r}^{2}$ and $\rho$ by using a computer program (Thomas and Gilroy, 1984). The percent error for all discharge measurements $(\alpha)$, discharge measurement dates, measured discharge, and the discharge-rating residuals were input to the program, which then computed estimates of $S_{m}^{2}, S_{p r}^{2}$, and $\rho$.

For several streamflow-gaging stations, use of equation 8 and the percent error of individual discharge measurements $\left(\alpha_{i}\right)$ as determined by using the Sauer and Meyer method resulted in an estimate for measurement variance that was greater than the variance of the discharge-rating residuals. This indicated that this empirical method of estimating measurement error can overestimate the measurement variance. The measurement variance should be equal to or less than the variance of the residuals (equation 9). For streamflow-gaging stations with a discharge rating that is not affected at all by physical processes, the measurement variance should equal the variance of the discharge-rating residuals, and the process variance should equal zero. For streamflow-gaging stations with a discharge rating that is affected by physical processes, then both the measurement variance and process variance should be less than the variance of the residuals.

To avoid overestimation of measurement variance, an alternative method of estimating measurement variance that uses semivariograms was developed as part of this study. The semivariogram of discharge-rating residuals is related to the variogram of discharge-rating residuals and is expressed as a graph of the gamma function (Chiles and Delfiner, 1999):

$$
\gamma(\Delta)=C(0)-C(\Delta)
$$

where

$$
\begin{aligned}
& \gamma(\Delta)=\text { the semivariogram; } \\
& C(0)=\text { the variance of the discharge-rating residuals; and } \\
& C(\Delta)=\text { the covariance of the discharge-rating residuals } \Delta \text { days apart. }
\end{aligned}
$$

The semivariogram is used more typically in spatial analyses and has three main properties: the sill, the nugget, and the range (fig. 12 this study; Chiles and Delfiner, 1999). A nonzero nugget is caused by measurement variance and small-scale variability; for this study it can be assumed that the nonzero nuggets are caused entirely by measurement variance. The range is the correlation time - the time interval at which observations are no longer correlated to a significant degree. The sill is a limiting value of the semivariogram that is reached after observations are no longer correlated; the nugget effect plus the process variance equals the sill. The semivariogram provides an alternative to estimating the measurement variance by using empirical methods. Conceptually, the semivariogram should provide a better estimate for measurement variance because measurement variance is determined from the discharge measurement data, which contain information about the measurement error. In contrast, measurement variance that is determined empirically on the basis of the percent error for individual discharge measurements is only a reflection of results found for similar, but not the actual, conditions encountered during the discharge measurements. A limitation, however, is that semivariograms only provide estimates for random error; therefore, bias errors in the discharge measurements are not accounted for. 


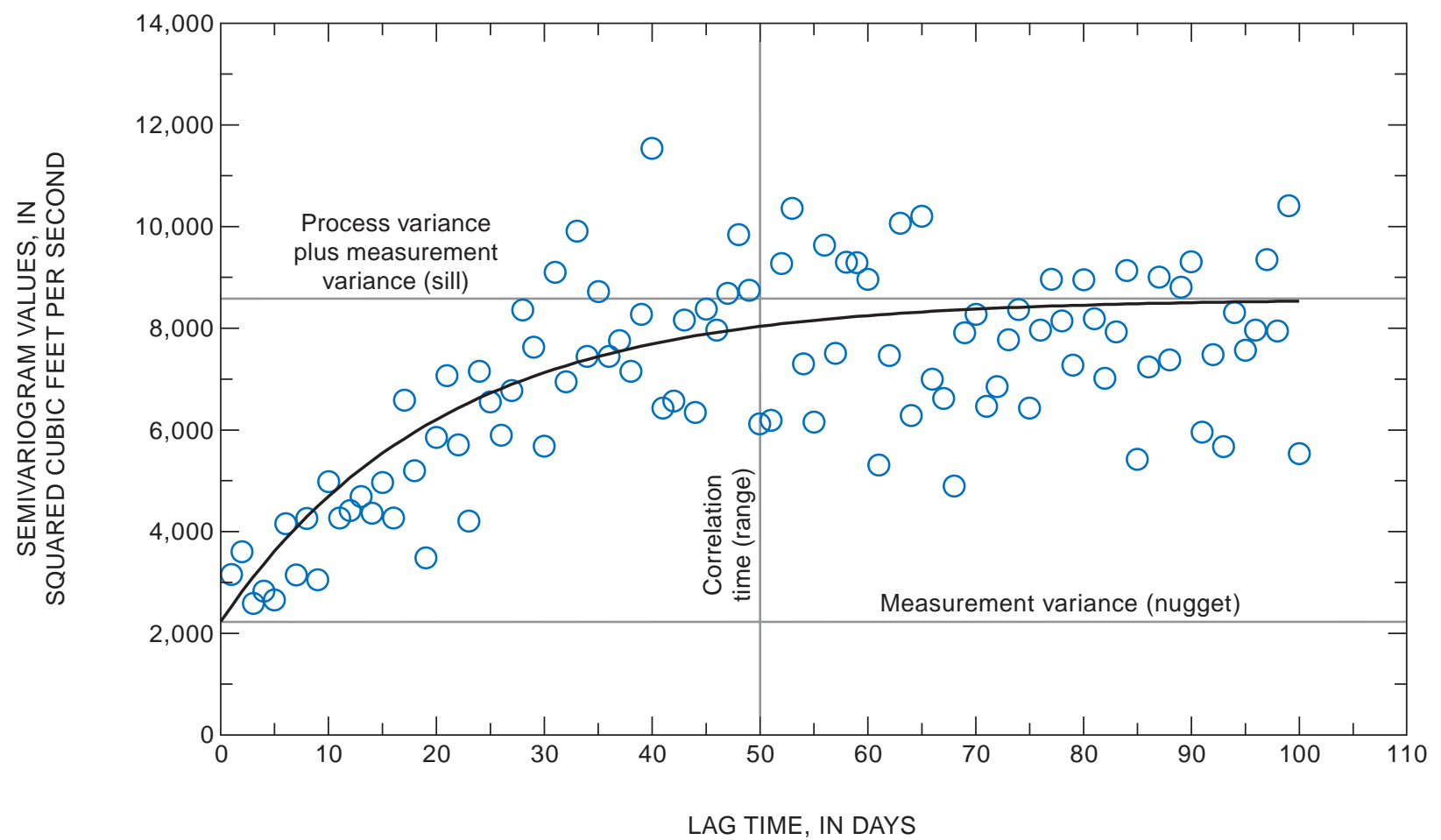

Figure 12. Semivariogram of discharge-rating residuals for Colorado River at the northerly international boundary with Mexico, July 28, 1995, to January 16, 1997. Blue circles represent the empirical semivariogram and the black line is nonlinear least squares fit theoretical semivariogram.

The measurement variance, process variance, and one-day serial-correlation coefficient were determined from semivariograms. For each set of discharge-rating residuals, an empirical semivariogram was developed by using computer software (MathSoft, 2000b). Then, nonlinear least squares was used to fit (MathSoft, 2000b) a theoretical semivariogram with an exponential form to the empirical semivariogram. The computer output includes a graph of the semivariogram with the modeled fit (Millard, 2001) and a listing of the nugget, sill, and range, which were used to determine the measurement variance, process variance, and one-day serial-correlation coefficient.

Several empirical semivariograms were not well defined, and acceptable theoretical semivariograms could not be fit by using the computer software, which required that the fit be made manually (fig. 13). In general, the poorly defined semivariograms resulted from infrequent discharge measurements where the time interval between discharge measurements was longer than the correlation time. The theoretical semivariograms were fit manually as follows. The variance of the residuals was used as an estimate of the sill, the measurement variance plus the process variance. If the measurement variance estimated on the basis of the $\alpha_{i}$ and equation 8 was less than the variance of the residuals, then this measurement variance was accepted. If this measurement variance was greater than the variance of the residuals, it was deemed unacceptable. In this case, the measurement variance was estimated on the basis of the discharge values for measurements made during that period and on the effective percent error for discharge measurements for either a different discharge-rating period at the same streamflow-gaging station or a discharge-rating period for a different streamflow-gaging station:

where

$$
S_{m}^{2}=\frac{1}{n} \sum_{i=1}^{n}\left(\frac{\alpha_{e}}{100} \times q_{m_{i}}\right)^{2},
$$

$\alpha_{e} \quad=\quad$ effective percent error for discharge measurements. 


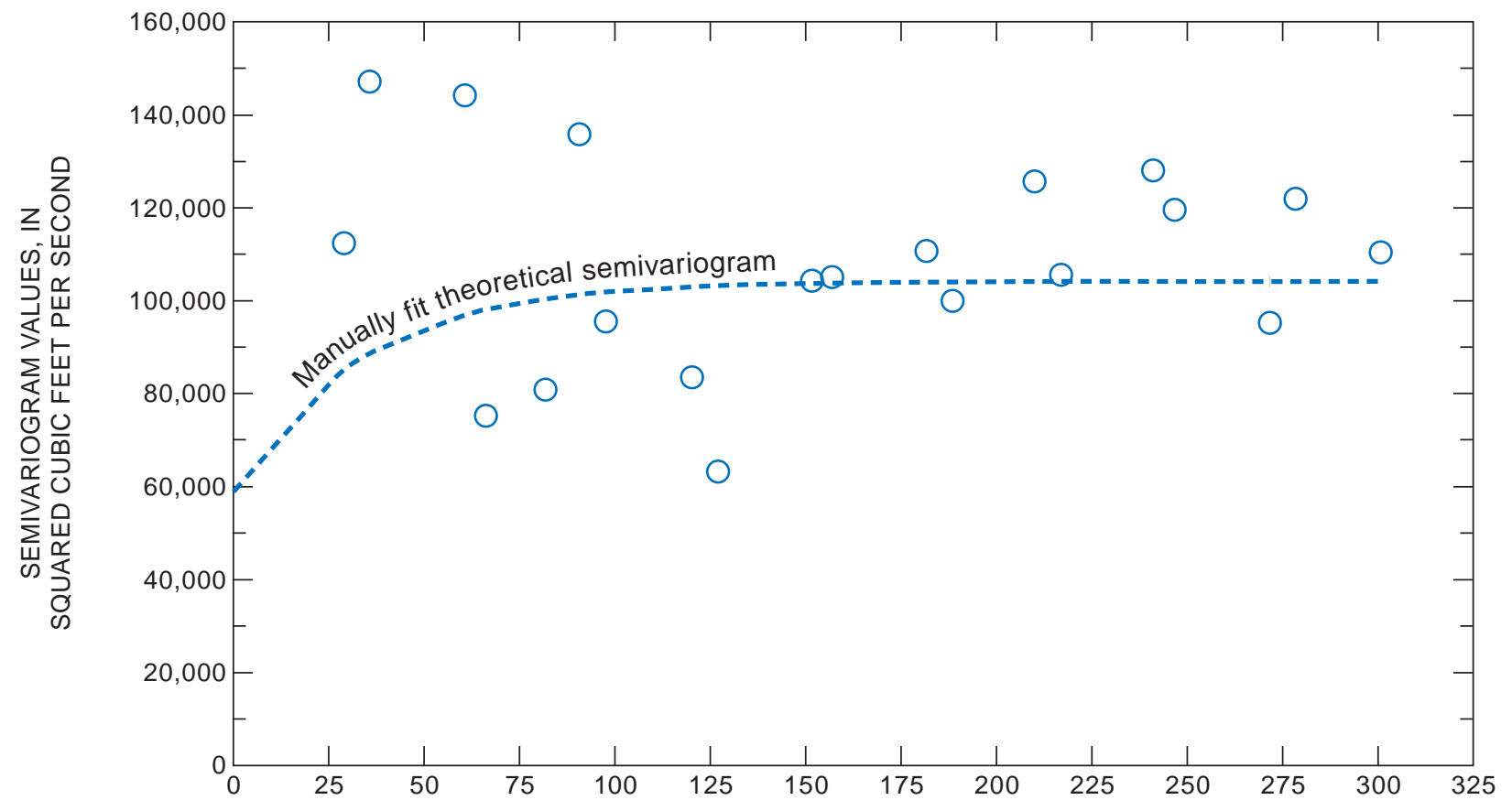

LAG TIME, IN DAYS

Figure 13. Semivariogram of discharge-rating residuals for Colorado River below Davis Dam, January 5, 1988, to December 31, 1999. Blue circles represent the empirical semivariogram.

The effective percent error does not vary by discharge measurement, but rather is an error representative of all discharge measurements, and is a mathematical construction that allows for estimation of the measurement variance for a set of discharge measurements for which estimates of the percent error $\left(\alpha_{i}\right)$ for individual discharge measurements are not available. The effective percent error for discharge measurements for equation 13 was backcalculated from data for a different discharge-rating period or streamflow-gaging station, and a rearrangement of equation 13:

$$
\alpha_{e}=100 \times \sqrt{\frac{S_{m}^{2}}{n}} .
$$

The correlation time for the poorly defined empirical semivariograms was estimated visually and, therefore, was subjective. In many cases, it appeared that the correlation time occurred before or near the first point of the empirical semivariogram. This puts a constraint on the maximum for the correlation time. With estimates of the nugget, sill, and correlation time, the theoretical semivariogram was fit manually. The one-day serial-correlation coefficient, $\rho$, was estimated graphically from two points on the manually fit theoretical semivariogram and equations 9 and 11 .

With estimates of measurement variance, process variance, and the one-day serial-correlation coefficient of the unbiased discharge-rating residuals, the variance of estimate of the annual discharge was determined by using Kalman-filter theory as described by Moss and Gilroy (1980). This was performed by using a computer program (Thomas and Gilroy, 1984), which in addition to the three previously mentioned parameters, also requires the 
number of days for the discharge volume to accumulate. Output from the program includes estimates of the variance of estimate of the annual discharge as a function of the number of discharge measurements made during the period (fig. 14). If the discharge rating covered the full year, then the number of days for the discharge volume to accumulate was 365 . There were, however, cases where two or more discharge-rating periods fell in a year. In these cases the period for the discharge volume to accumulate would only be as long as the number of days in that particular year that the discharge rating was valid. The variances of estimate of the discharge volumes for these discharge-rating periods were weighted on the basis of the fraction of the year that the discharge rating was valid and then combined into the variance estimate of the annual discharge (Fontaine and others, 1984, p. 33; Fontaine, 1983, p. 12):

$$
S_{\bar{Q}}^{2}=\sum_{i=1}^{p}\left(\frac{r}{365}\right)^{2} \times S_{Q_{i}}^{2},
$$

where

$$
\begin{aligned}
S_{\bar{Q}}^{2} & =\text { variance of estimate of the annual discharge; } \\
S_{Q_{i}}^{2} & =\begin{array}{l}
\text { variance of estimate for the discharge volume that occurred during the discharge-rating } \\
\text { period }
\end{array} \\
r & =\text { number of days in discharge-rating period } i \text { during the year of interest; and } \\
p & =\text { number of discharge-rating periods during the year. }
\end{aligned}
$$

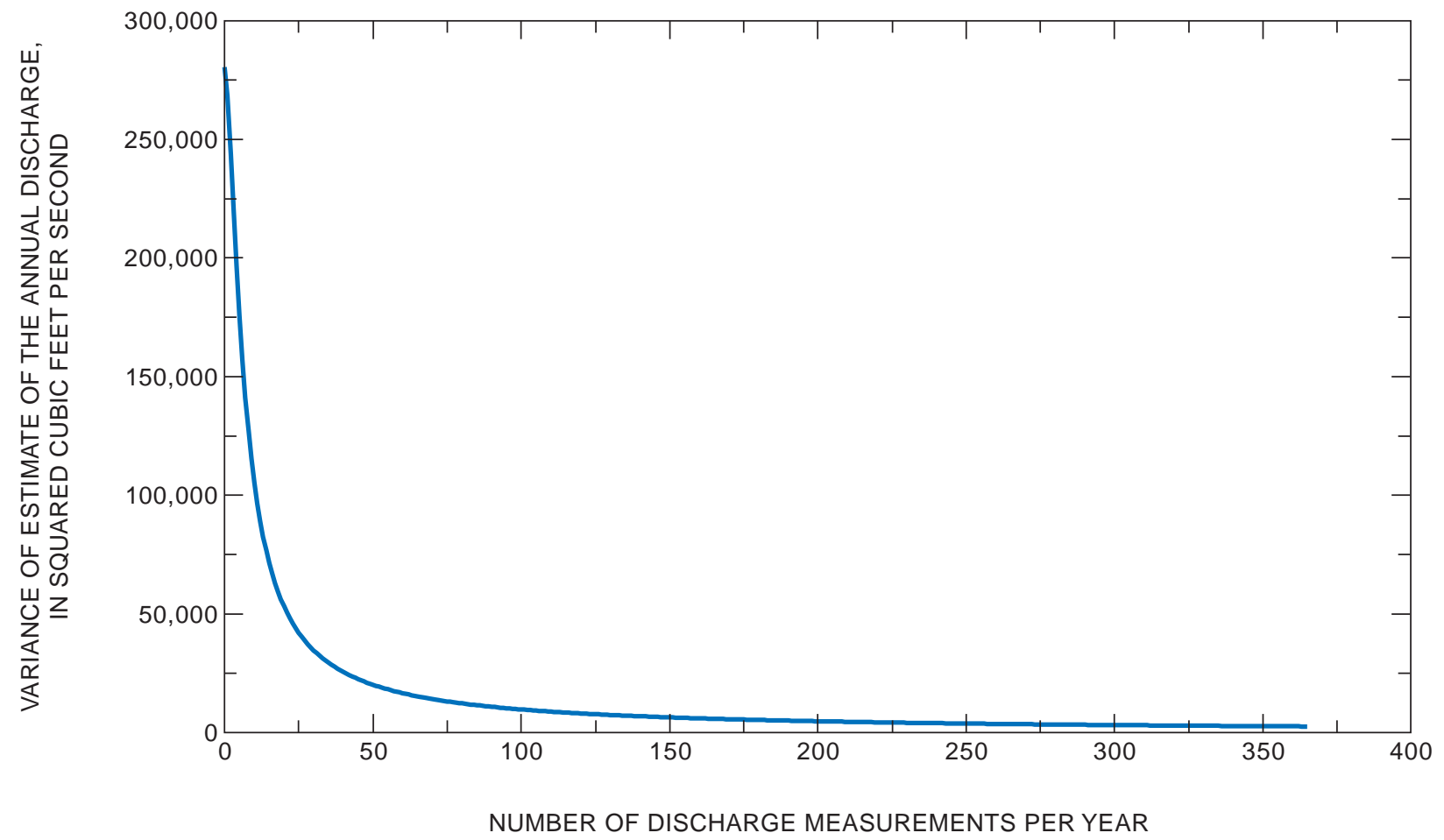

Figure 14. Variance of estimate of the annual discharge for 1996 at Colorado River at the northerly international boundary with Mexico as a function of the number of discharge measurements used to compute the discharge record that year. 
Fontaine (1983) determined the variance of estimate of discharge volumes for periods affected by ice and also the variance of estimate of discharge volumes for ice-free periods by using the Moss and Gilroy method (1980), and then combined these into the variance of estimate of the annual discharge by using equation 15 .

The uncertainty in the annual discharge can greatly increase for periods where the continuous record of the correlative variable, such as stage, is missing because of equipment failures and such. For the period of 1995-99 examined in this study, missing record was not an issue. A method that considers the effects of missing record on the standard error of the annual discharge was developed by Moss in Fontaine and others, 1984. The computer software used to determine the variance of estimate of the annual discharge has an option to account for the effects of missing record by using this method (Thomas and Gilroy, 1984).

\section{METHODS OF ESTIMATING THE STANDARD ERROR OF THE ANNUAL CHANGE IN RESERVOIR CONTENT}

Computed reservoir content data were determined on the basis of a continuous record of stage and a stagecontent rating that was determined from topographic data for the reservoir basin. Change in reservoir content is computed by subtracting the initial reservoir content from the ending reservoir content:

$$
\Delta S_{r}=S_{r_{2}}-S_{r_{1}}
$$

where

$$
\begin{aligned}
\Delta S_{r} & =\text { change in reservoir content; } \\
S_{r_{1}} & =\text { initial reservoir content; and } \\
S_{r_{2}} & =\text { ending reservoir content. }
\end{aligned}
$$

Annual change in content is calculated as the difference between the reservoir contents at midnight on December 31 of one year and the reservoir contents at midnight on December 31 of the previous year.

Uncertainty in the change in reservoir content results from the uncertainty in the two reservoir-stage readings and from errors in the stage-content rating. Uncertainty in the reservoir-stage readings can result from instrumentation errors, such as those associated with zeroing the stage recorder during site visits. Much larger errors in reservoir content, however, may result from conditions where the reservoir-surface elevation at the location of the recording equipment is misrepresentative of the reservoir surface. Both Lake Mohave and Lake Havasu are large, long reservoirs (fig. 1), and the reservoir-surface elevation at the upstream end may differ from that at the downstream end, where the recording instruments are located, because of unsteady reservoir inflows and outflows, or from sustained winds that shift the mass of the reservoir in the direction of the wind. Other factors, such as drawdown from withdrawal intakes for downstream releases or wind generated waves, may affect the reservoir-surface elevation locally near the recording instruments. The reservoir-content gaging station for Lake Mohave is near the power-generation intakes at Davis Dam, and the reservoir-content gaging station for Lake Havasu is at the pumping plant intakes for the Colorado River Aqueduct diversion.

Errors in the reservoir basin topographic-survey data and interpolation errors of these data will result in a biased reservoir stage-content rating. Bias in reservoir content can result from sediment that is deposited after the reservoir stage-content rating is developed. Bias in the change in reservoir content will be smaller than bias for reservoir content because the bias associated with the volume in storage that is common to both dates will cancel each other. 
Neglecting bias in the reservoir stage-content rating, the uncertainty in change in content data are dependent on the surface area of the reservoir at the two stages of interest, and on the errors of the reservoir-stage readings:

$$
S_{\Delta S_{r}}=\sqrt{S_{h_{1}}^{2} \times A_{1}+S_{h_{2}}^{2} \times A_{2}}
$$

where

$$
\begin{aligned}
S_{\Delta S_{r}} & =\text { standard error of the change in reservoir content; } \\
S_{h_{1}} \text { and } S_{h_{2}} & =\text { standard errors of the reservoir-stage readings } h_{1} \text { and } h_{2} \text {, respectively, and } \\
A_{1} \text { and } A_{2} & =\text { the reservoir surface areas for stages } h_{1} \text { and } h_{2} \text {, respectively. }
\end{aligned}
$$

The reservoir surface areas for stages $h_{1}$ and $h_{2}$ can be determined directly from the reservoir stage-area rating or indirectly from the reservoir stage-contents rating by noting that the reservoir surface area at a given stage equals the instantaneous rate of change in reservoir contents with respect to a change in stage, $d S_{r}$.

$$
\overline{d h}
$$

Standard errors for the reservoir-stage readings were estimated from the reservoir-stage record. Ideally the stage record for large reservoirs is a smooth trace over time; however, wind and other factors previously mentioned introduce noise and, therefore, uncertainty into the reservoir-stage record. If the reservoir-stage record is mathematically smoothed, then the residuals of the reservoir-stage record from the smoothed reservoir-stage record can be used to provide an estimate of the uncertainty in an individual stage reading.

A smoothed reservoir-stage record of 15-minute data for Lake Mohave from December 26, 1999, to January 5, 2000, was made by using the locally weighted scatter plot smoothing option (LOWESS; Cleveland, 1979) in a computer software package (fig. 15; MathSoft, 2000a). Stage data for these 10 days near the end of the calendar year were selected because they include the data that are used to calculate change in reservoir contents (the stage at midnight on December 31) and because the uncertainty in the reservoir-stage record may vary seasonally. The standard error of the residuals from the smoothed reservoir-stage record, $0.073 \mathrm{ft}$, was used as an estimate for the standard error of a reservoir-stage reading, $S_{h}$. The amount of smoothing for a LOWESS smooth is controlled by the "span" that is used; the span can range from 0.0 to 1.0, and for this investigation a span of 0.25 was found to be appropriate. This span removed the noise and most of the diurnal pattern in the reservoir-stage record (fig. 15). The diurnal pattern in the reservoir-stage record may have resulted from diurnal patterns in reservoir inflows, releases and diversions from the reservoir, and wind. If the diurnal pattern is caused mostly by reservoir inflows, releases, and diversions, then the span of 0.25 may result in an overestimate of the standard error of the reservoirstage readings because the span results in a smooth with a dampened diurnal amplitude (fig. 15). On the other hand, this method may underestimate the standard error of the reservoir-stage reading because it does not fully account for spatially varying reservoir-surface elevations by utilizing information about the differences between the reservoir-surface elevation at the gage and the elevation at other locations throughout the reservoir. For Lake Mohave, 15-minute reservoir-stage data were unavailable for the same 10-day periods in 1995-98, so $0.073 \mathrm{ft}$ was used as an estimate for the standard error of the stage reading at midnight on December 31 of calendar years 1994-99.

For Lake Havasu, 15-minute reservoir-stage data were available in electronic format for calendar years 19952000 (fig. 15 for December 26, 1999, to January 5, 2000). Residual standard errors for the smoothed reservoir-stage records were computed for the same 10-day periods of each year and were $0.066,0.067,0.068,0.048$, and 0.050 , for the periods ending on January 5 of 1996, 1997, 1998, 1999, and 2000, respectively. The square root of the mean of these standard errors squared, $0.060 \mathrm{ft}$, was used as an estimate for the standard error of the stage reading at midnight of December 31 of calendar years 1994-99 at this station. 

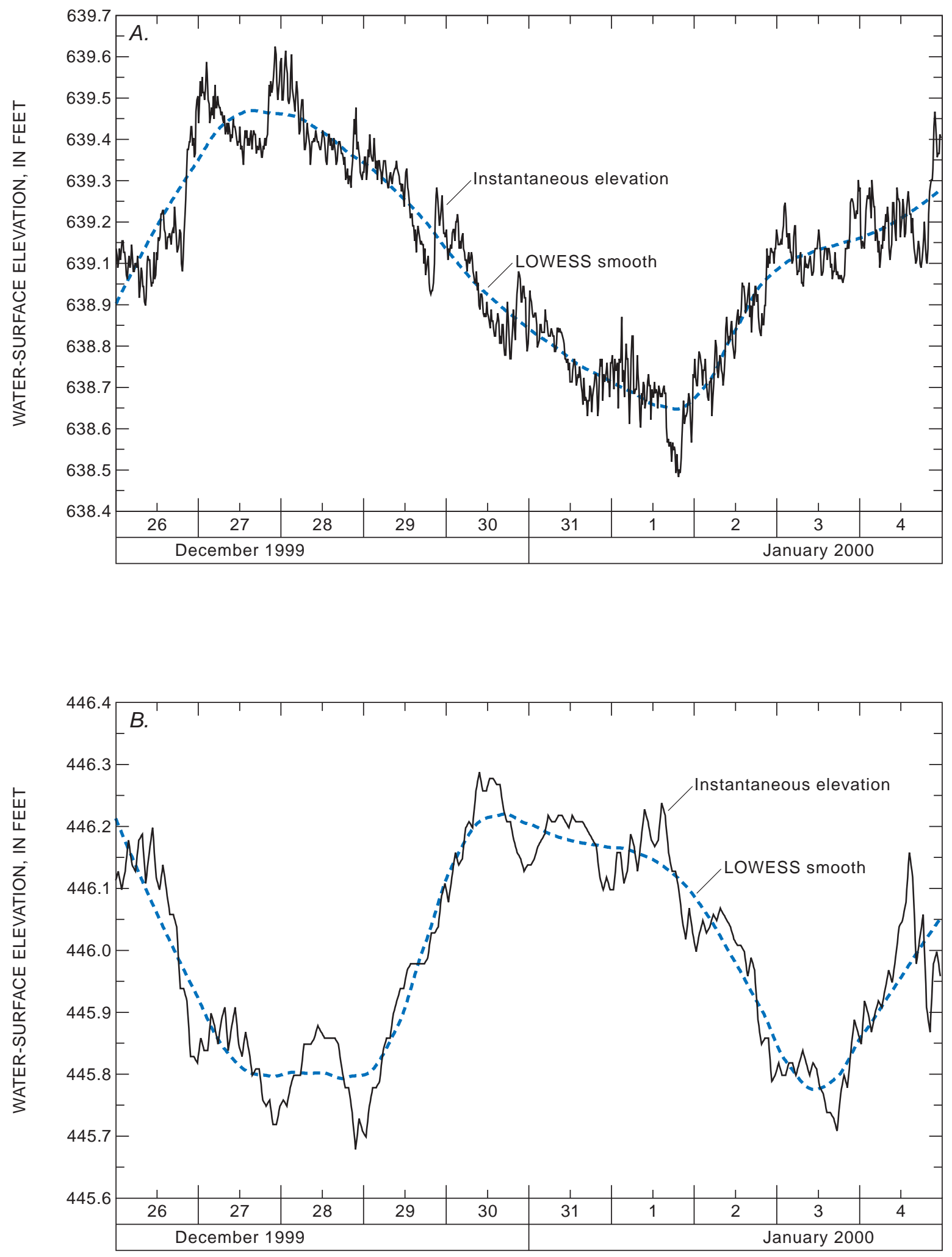

Figure 15. Time series of the instantaneous water-surface elevation and the LOWESS smooth of that series for December 26, 1999, to January 5, 2000. A, Lake Mohave at Davis Dam. B, Lake Havasu near Parker Dam. 


\section{APPLICATION OF THE METHODS FOR STREAMFLOW-GAGING STATIONS}

The standard error of the annual discharge for 1995-99 was estimated for the streamflow-gaging stations listed in table 1. The details of applying the error estimation methods are described for each streamflow-gaging station in this section. The modified Moss and Gilroy method requires the assumption of unbiased discharge-rating residuals because the mathematics of the Kalman-filter theory do not account for bias. Bias in the discharge measurements at a given station, if any, will be propagated to the discharge-rating residuals but will not be accounted for. For this reason, the standard errors presented in this report only represent the random error in the annual discharge data. Bias error is further discussed in the section "Improvements for standard-error estimates."

The Kalman-filter theory used by the modified Moss and Gilroy method requires the assumption of unbiased discharge-rating residuals because the mathematics of the filter do not account for bias. For this reason, the standard errors presented in this report only represent the random error in the annual discharge data.

There was not sufficient data to perform the error analysis for three streamflow-gaging stations: Colorado River below Hoover Dam (site 1, figs. 1 and 2), Colorado River Aqueduct (site 4, figs. 1 and 2), and Central Arizona Project Canal (site 6, figs. 1 and 2). The Colorado River below Hoover Dam is gaged by multipath AVMs in the penstocks of the dam. The actual error may have increased since the initial calibration because of drift in the index velocity measurements. The cross-sectional area of the penstocks probably has remained the same and would not be considered a source of error. Data are furnished by the BOR and published by the USGS in the annual data reports for Arizona (such as Tadayon and others, 2000).

Owen-Joyce and Raymond (1996) report that in 1986 the computed discharge determined from AVMs in the penstocks at Hoover Dam was consistently different from discharge measured by using vertical-axis current meters at Colorado River below Hoover Dam (site 1, figs. 1 and 2). Computed discharges determined from the AVMs were consistently smaller than the measured discharges, and the discrepancy increased in magnitude from near 0 at $5,000 \mathrm{ft}^{3} / \mathrm{s}$ to 2.9 percent at discharges above $30,000 \mathrm{ft}^{3} / \mathrm{s}$ (Owen-Joyce and Raymond, 1996, table 6). The AVMs at Hoover Dam have been upgraded since 1986, but it is not certain how the upgrade has affected these biases because discharge has not been measured to verify the AVM data.

Diversions from Lake Havasu are pumped up to the Colorado River Aqueduct through nine pipes and are monitored with AVMs. The Metropolitan Water District of Southern California operates the AVMs and provides daily discharges for the Colorado River Aqueduct (site 4, figs. 1 and 2) to the USGS for publishing in the annual data reports for Arizona (such as Tadayon and others, 2000). The USGS has not verified the computed discharges with discharge measurements because there are no open channels in the vicinity of the AVMs.

Water in Lake Havasu is also pumped into the Central Arizona Project Canal, and these diversions are also monitored with AVMs. The Central Arizona Water Conservation District operates the AVMs and provides daily discharges for the Central Arizona Project Canal at Havasu Pumping Plant (site 6, figs. 1 and 2) to the USGS for publishing in the annual data reports for Arizona (such as Tadayon and others, 2000). The USGS has not verified the computed discharges with discharge measurements because there are no open channels in the vicinity of the AVMs.

\section{Colorado River below Davis Dam}

The Colorado River below Davis Dam streamflow-gaging station (site 3, figs. 1 and 2) is located on a straight section of channel about $0.5 \mathrm{mi}$ downstream from Davis Dam and is operated by the USGS. Streamflow for 199599 was computed on the basis of a stage-discharge relation. Discharge was measured from a cableway near the gage house by using vertical-axis current meters, and stage was monitored continuously with a float-tape gage inside a stilling well. On the basis of 100 stage and discharge measurements made during 1988-99, a single, timedependent stage-discharge rating was developed (table 3). A theoretical semivariogram of the discharge-rating residuals was fit manually (fig. 16). Measurement variance could not be determined clearly from the empirical semivariogram. Equation 13 and $\alpha_{e}$ for All-American Canal near Imperial Dam (site 16, figs. 1 and 2), 1.45 percent, were used to estimate the measurement variance for this station because the measurement variance 
determined from equation 8 and $\alpha_{i}$ was much larger than the variance of the discharge-rating residuals. The value of $\alpha_{e}$ for All-American Canal near Imperial Dam was chosen over that for other stations because the widths, depths, velocities, and bottom stability for this station were most similar to those of Colorado River below Davis Dam. Application of the modified Moss and Gilroy method yielded estimates of the standard error of the annual discharge for 1995-99 that ranged from 0.41 to 0.55 percent (table 3). The time interval between discharge measurements was variable within a given year for 1995-99, which violates the assumption of a consistent time interval between measurements. Therefore, the actual uncertainty of the annual discharge may be larger than that reported.

Table 3. Summary of error-analysis results for the annual discharge at Colorado River below Davis Dam

[ $q_{r}$, discharge; $h$, gage height; $t$, time in decimal years; $\mathrm{ft}^{3} / \mathrm{s}$, cubic feet per second]

\section{Summary of discharge-rating residuals}

Discharge-rating period

Discharge-rating equation

Number of discharge measurements

Average discharge for

measurements, $\mathrm{ft}^{3} / \mathrm{s}$

Effective percent error for discharge measurements

Measurement variance, $\left(\mathrm{ft}^{3} / \mathrm{s}\right)^{2}$

Process variance, $\left(\mathrm{ft}^{3} / \mathrm{s}\right)^{2}$

One-day serial-correlation coefficient for discharge-rating residuals

\section{$1 / 5 / 88$ to $12 / 31 / 99$}

$$
q_{r}=320.0(h-4.03+0.013(t-1995))^{1.82}
$$

100

15,000

1.45

58,900

45,300

0.970

\begin{tabular}{|c|c|c|c|c|c|}
\hline \multicolumn{6}{|c|}{ Uncertainty in the annual discharge } \\
\hline & 1995 & 1996 & 1997 & 1998 & 1999 \\
\hline Number of discharge measurements & 8 & 4 & 4 & 4 & 5 \\
\hline Annual discharge, acre-feet & $8,318,000$ & $9,904,000$ & $11,530,000$ & $12,940,000$ & $11,070,000$ \\
\hline $\begin{array}{l}\text { Variance of estimate of the annual } \\
\text { discharge, }(\text { acre-feet })^{2}\end{array}$ & $2,060,000,000$ & $2,815,000,000$ & $2,815,000,000$ & $2,815,000,000$ & $2,584,000,000$ \\
\hline $\begin{array}{l}\text { Standard error of the annual } \\
\text { discharge, acre-feet }\end{array}$ & 45,390 & 53,070 & 53,070 & 53,070 & 50,820 \\
\hline $\begin{array}{l}\text { Standard error of the annual } \\
\text { discharge, percent }\end{array}$ & 0.55 & 0.54 & 0.46 & 0.41 & 0.46 \\
\hline
\end{tabular}




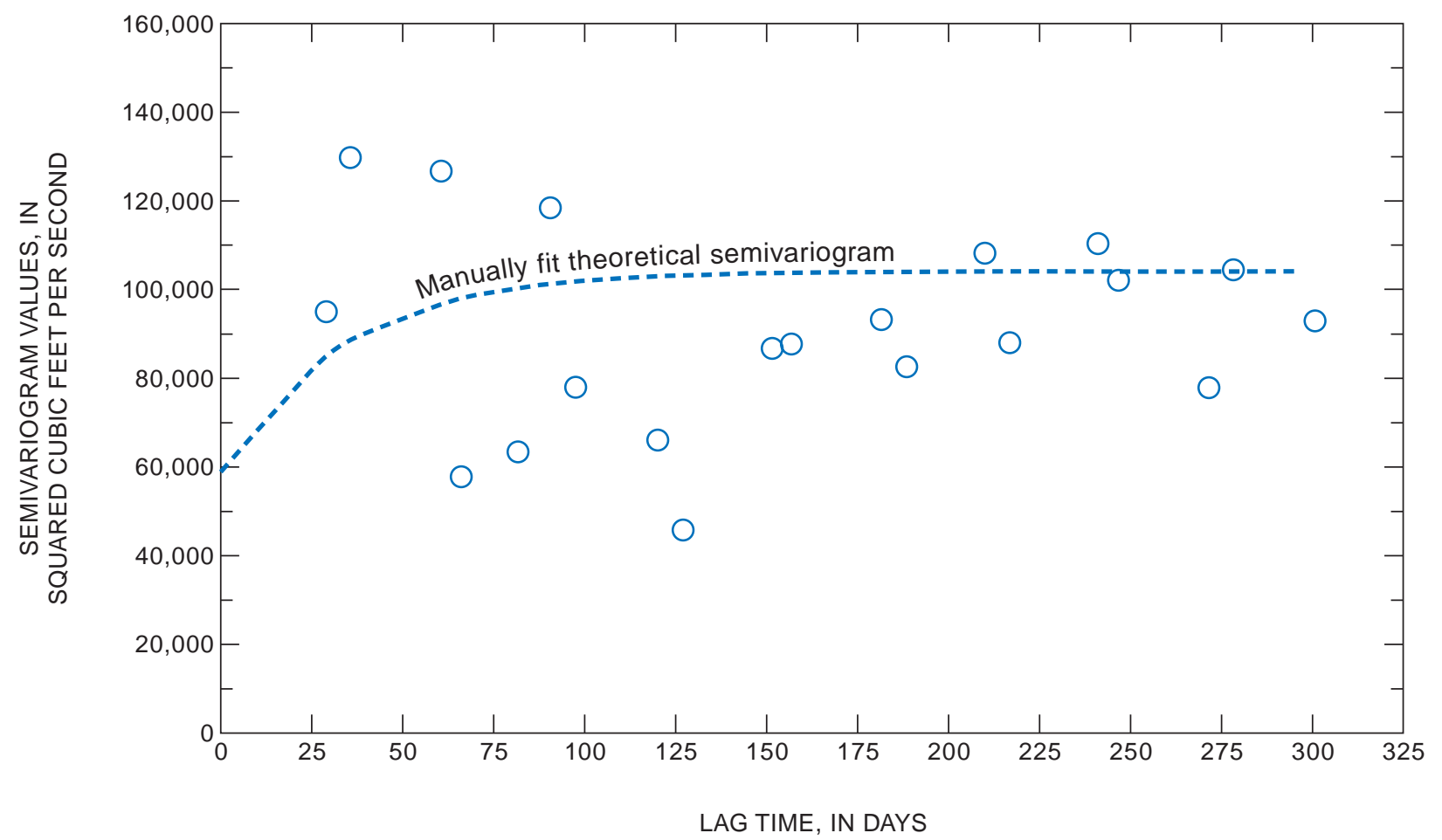

Figure 16. Semivariograms of discharge-rating residuals for Colorado River below Davis Dam, January 5, 1988, to December 31, 1999. Blue circles represent the empirical semivariogram.

\section{Bill Williams River below Alamo Dam}

The Bill Williams River below Alamo Dam streamflow-gaging station (site 5, figs. 1 and 2) is on a straight section of channel about 0.6 mi downstream from Alamo Dam and is operated by the USGS. Streamflow for 1996-99 was computed on the basis of a stage-discharge relation. During low flows, discharge was measured by using vertical-axis current meters at a wadable cross section about $0.10 \mathrm{mi}$ above the gage house; however, during high flows, discharge was measured from a cableway near the gage house. Stage was monitored continuously by a bubble gage. A flood in 1993 washed out a weir that controlled the stage at some flows, and a new control was constructed about $30 \mathrm{ft}$ downstream from the manometer orifice in 1997. The new control structure has been ineffective in controlling stage because of fill downstream from the structure. While the control structure was under construction (late-October 1997 through mid-March 1998), discharge was estimated on the basis of dam-release information provided by the dam operators and by interpolating discharge between periodic discharge measurements. Releases from Alamo Dam were fairly consistent from day to day throughout the construction period. Large discharges were released from Alamo Dam during January, February, and the beginning of March of 1995, and constitute most of the annual discharge for 1995. The number of available discharge measurements for this period of high flow was not sufficient to determine the parameters needed for the modified Moss and Gilroy method, and so error was estimated only for years 1996-99. On the basis of 30 stage and discharge measurements made from March 1995 through October 1997, a time-dependent stage-discharge rating was developed for that period (table 4). Another time-dependent stage-discharge rating was developed for the period subsequent to construction of the control structure on the basis of 22 stage and discharge measurements that were made from March 1998 through December 1999 (table 4). Theoretical semivariograms of the two sets of discharge-rating residuals were fit manually (figs. 17A and 17B). Measurement variance could not be determined clearly from the 
empirical semivariograms, so it was estimated on the basis of equation 8 and $\alpha_{i}$. The effective percent error for discharge measurements (4.2 percent for the period before construction of the control structure, and 4.0 percent for the period after construction of the control structure) for this station was larger than that for other streamflowgaging stations investigated in this study because of the shallow stream depths and rough streambed of the measurement section that generally consisted of gravel, cobbles, and boulders. Application of the modified Moss and Gilroy method yielded estimates of the standard error of the annual discharge for 1996-99 that ranged from 1.70 to 3.65 percent. For the period in 1997 and 1998 that the new control was under construction, it was assumed that estimating streamflow on the basis of discharge measurements and flow-release information provided by the operators of the Alamo Dam resulted in a similar error as when streamflow was estimated on the basis of a stagedischarge relation.

Table 4. Summary of error-analysis results for the annual discharge at Bill Williams River below Alamo Dam

$\left[q_{r}\right.$, discharge; $h$, gage height; $t$, time in decimal years; $\mathrm{ft}^{3} / \mathrm{s}$, cubic feet per second; ---, not determined]

\section{Summary of discharge-rating residuals by discharge-rating period}

Discharge-rating period

Discharge-rating equation

Number of discharge measurements

Average discharge for measurements, $\mathrm{ft}^{3} / \mathrm{s}$

Effective percent error for discharge measurements

Measurement variance, $\left(\mathrm{ft}^{3} / \mathrm{s}\right)^{2}$

Process variance, $\left(\mathrm{ft}^{3} / \mathrm{s}\right)^{2}$

One-day serial-correlation coefficient for dischargerating residuals
$3 / 17 / 95$ to $10 / 27 / 97$

$$
q_{r}=28.6(h-10.27-0.247(t-1995))
$$

43

\section{$3 / 20 / 98$ to $12 / 31 / 99$}

$$
q_{r}=19.7(h-7.98-0.367(t-1995))
$$

22

36.0

4.0

2.16

38.0

\begin{tabular}{|c|c|c|c|c|c|}
\hline \multicolumn{6}{|c|}{ Uncertainty in the annual discharge } \\
\hline & 1995 & 1996 & 1997 & 1998 & 1999 \\
\hline $\begin{array}{l}\text { Number of discharge } \\
\text { measurements }\end{array}$ & --- & 13 & 11 & 15 & 10 \\
\hline Annual discharge, acre-feet & --- & 19,260 & 10,930 & 25,340 & 16,940 \\
\hline $\begin{array}{l}\text { Variance of estimate of the } \\
\text { annual discharge, (acre- } \\
\text { feet })^{2}\end{array}$ & --- & 107,500 & 134,300 & 202,900 & 382,100 \\
\hline $\begin{array}{l}\text { Standard error of the annual } \\
\text { discharge, acre-feet }\end{array}$ & --- & 327 & 366 & 451 & 618 \\
\hline $\begin{array}{l}\text { Standard error of the annual } \\
\text { discharge, percent }\end{array}$ & --- & 1.70 & 3.35 & 1.78 & 3.65 \\
\hline
\end{tabular}

0.974 


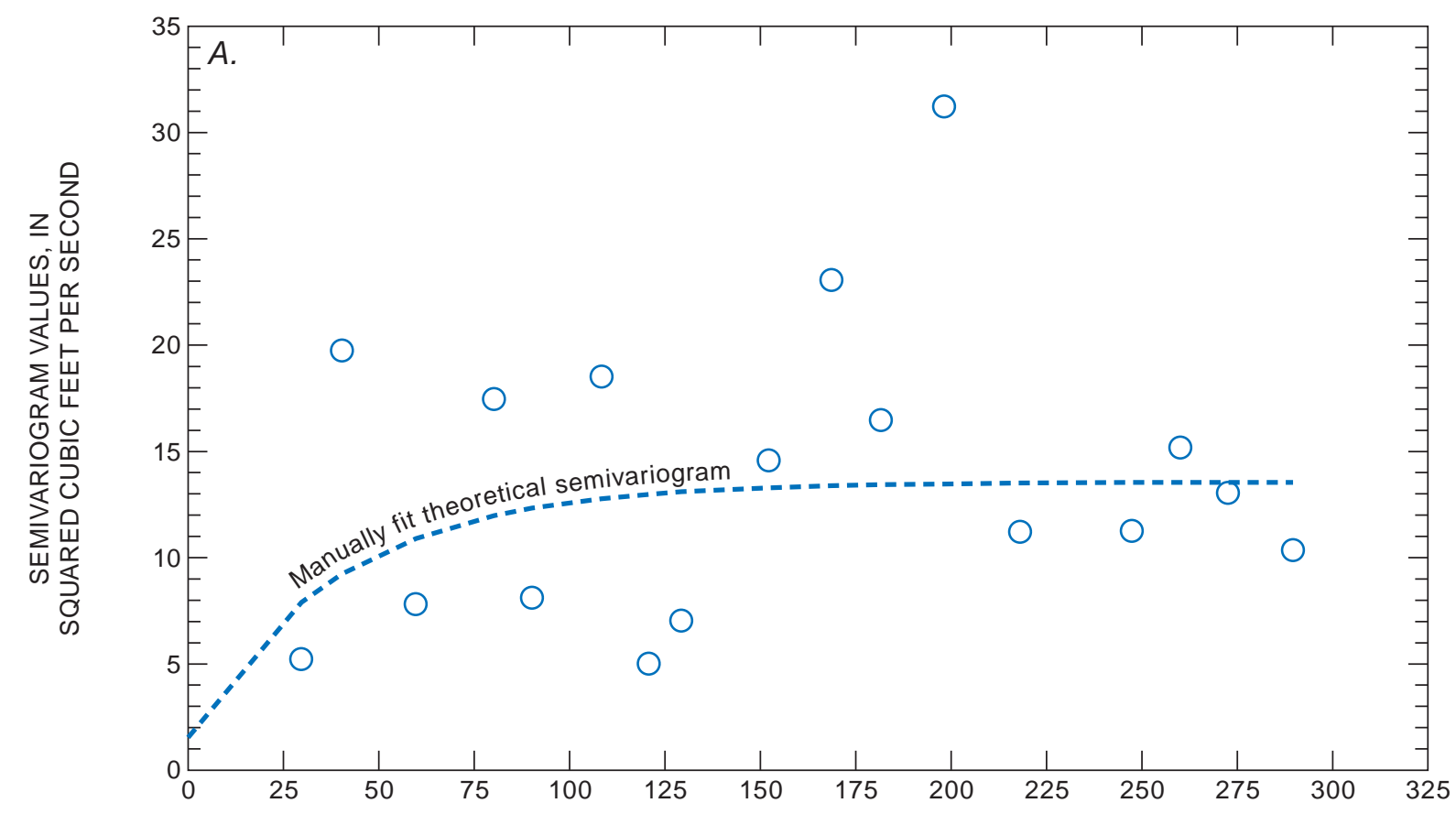

LAG TIME, IN DAYS

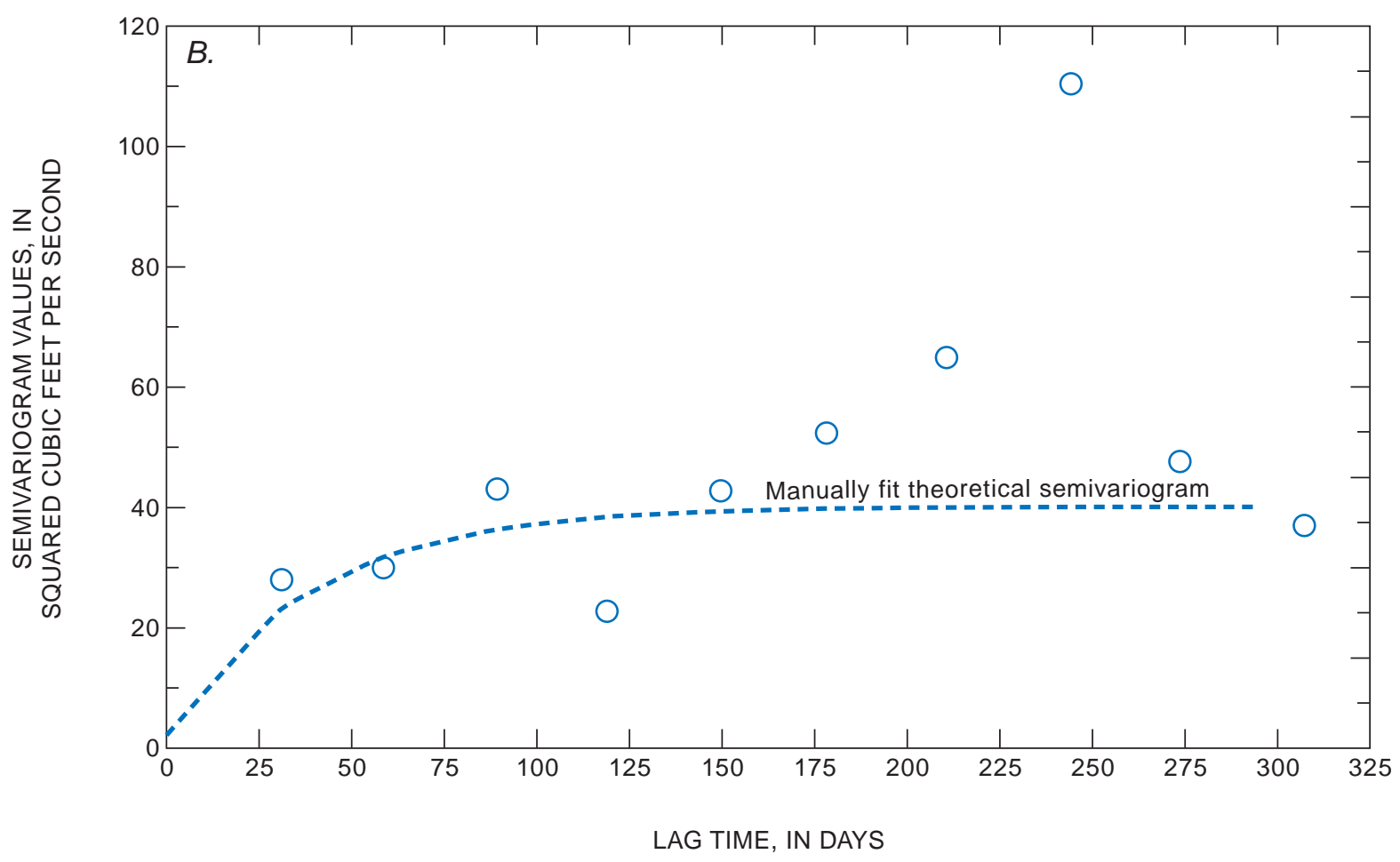

Figure 17. Semivariograms of discharge-rating residuals for Bill Williams River below Alamo Dam. A, March 17, 1995, to October 27, 1997. B, March 20, 1998, to December 31, 1999. Blue circles represent the empirical semivariogram. 


\section{Colorado River below Parker Dam}

The Colorado River below Parker Dam streamflow-gaging station (site 8, figs. 1 and 2) is at the Parker Dam power plant and is operated by the USGS. Streamflow for 1995-99 was computed on the basis of a stage-discharge relation. Discharge was measured from a cableway about $0.4 \mathrm{mi}$ downstream from the gage house by using verticalaxis current meters, and stage was monitored continuously with a float-tape gage inside a stilling well. On the basis of 54 stage and discharge measurements made during 1995-99, a single time-dependent stage-discharge rating was developed (table 5). A theoretical semivariogram of the discharge-rating residuals was fit manually (fig. 18). Measurement variance could not be determined clearly from the empirical semivariogram. Equation 13 and $\alpha_{e}$ for the All-American Canal near Imperial Dam (site 16, figs. 1 and 2), 1.45 percent, were used to estimate the measurement variance for this station because the measurement variance determined from equation 8 and $\alpha_{i}$ was much larger than the variance of the discharge-rating residuals. The value of $\alpha_{e}$ for All-American Canal near Imperial Dam was chosen over that for other stations because the widths, depths, velocities, and bottom stability for this station were most similar to those of the Colorado River below Parker Dam. Application of the modified Moss and Gilroy method yielded estimates of the standard error of the annual discharge for 1995-99 that ranged from 0.34 to 0.52 percent (table 5).

Table 5. Summary of error-analysis results for the annual discharge at Colorado River below Parker Dam

[ $q_{r}$, discharge; $h$, gage height; $t$, time in decimal years; $\mathrm{ft}^{3} / \mathrm{s}$, cubic feet per second]

\begin{tabular}{|c|c|c|c|c|c|}
\hline \multicolumn{6}{|c|}{ Summary of discharge-rating residuals } \\
\hline Discharge-rating period & $1 / 1 / 95$ to $12 / 31 / 99$ & & & & \\
\hline $\begin{array}{l}\text { Discharge-rating } \\
\text { equation }\end{array}$ & $q_{r}=502(h-62.53-0$. & $0(t-1995)+0.254 \cos ($ & $+0.095 \sin (2 \pi t))^{1.61}$ & & \\
\hline $\begin{array}{l}\text { Number of discharge } \\
\text { measurements }\end{array}$ & 54 & & & & \\
\hline $\begin{array}{l}\text { Average discharge for } \\
\text { measurements, } \mathrm{ft}^{3} / \mathrm{s}\end{array}$ & 13,500 & & & & \\
\hline $\begin{array}{l}\text { Effective percent error } \\
\text { for discharge } \\
\text { measurements }\end{array}$ & 1.45 & & & & \\
\hline $\begin{array}{l}\text { Measurement variance, } \\
\left(\mathrm{ft}^{3} / \mathrm{s}\right)^{2}\end{array}$ & 41,600 & & & & \\
\hline Process variance, $\left(\mathrm{ft}^{3} / \mathrm{s}\right)^{2}$ & 37,200 & & & & \\
\hline $\begin{array}{l}\text { One-day serial- } \\
\text { correlation coefficient } \\
\text { for discharge-rating } \\
\text { residuals }\end{array}$ & 0.970 & & & & \\
\hline \multicolumn{6}{|c|}{ Uncertainty in the annual discharge } \\
\hline & 1995 & 1996 & 1997 & 1998 & 1999 \\
\hline $\begin{array}{l}\text { Number of discharge } \\
\text { measurements }\end{array}$ & 12 & 11 & 12 & 12 & 11 \\
\hline $\begin{array}{l}\text { Annual discharge, acre- } \\
\text { feet }\end{array}$ & $6,718,000$ & $7,283,000$ & $8,470,000$ & $10,380,000$ & $8,355,000$ \\
\hline $\begin{array}{l}\text { Variance of estimate of } \\
\text { the annual discharge, } \\
\text { (acre-feet })^{2}\end{array}$ & $1,232,000,000$ & $1,305,000,000$ & $1,232,000,000$ & $1,232,000,000$ & $1,305,000,000$ \\
\hline $\begin{array}{l}\text { Standard error of the } \\
\text { annual discharge, } \\
\text { acre-feet }\end{array}$ & 35,040 & 36,130 & 35,040 & 35,040 & 36,130 \\
\hline $\begin{array}{l}\text { Standard error of the } \\
\text { annual discharge, } \\
\text { percent }\end{array}$ & 0.52 & 0.50 & 0.41 & 0.34 & 0.43 \\
\hline
\end{tabular}




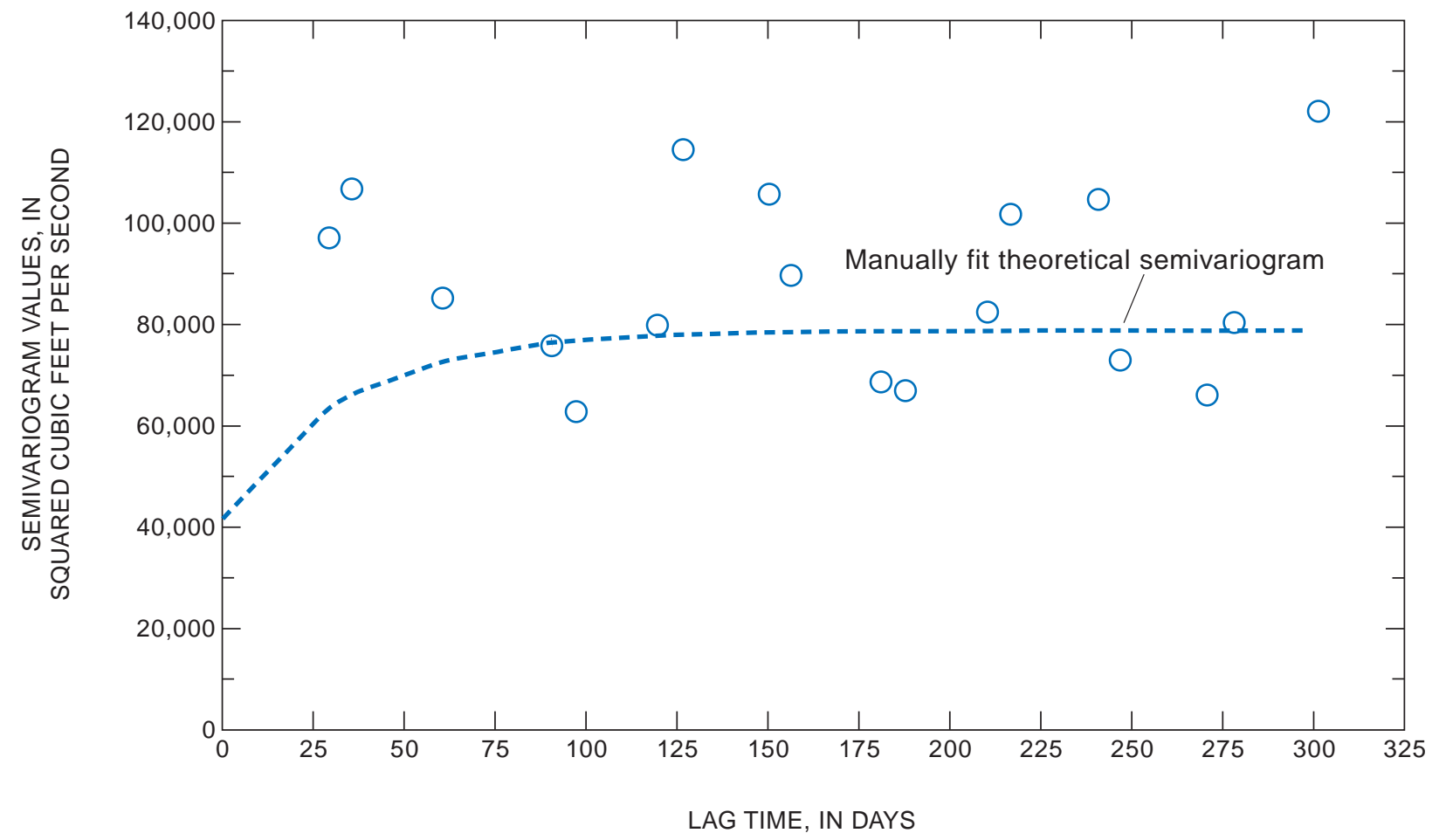

Figure 18. Semivariograms of discharge-rating residuals for Colorado River below Parker Dam, January 1, 1995, to December 31, 1999. Blue circles represent the empirical semivariogram.

\section{Colorado River above Imperial Dam}

Streamflow for 1995-99 at the Colorado River above Imperial Dam (site 9, figs. 1 and 2) streamflow-gaging station is computed by the USGS as the sum of the discharge at (fig. 19):

1.) Colorado River below Imperial Dam (site 10, figs. 1 and 2);

2.) All-American Canal near Imperial Dam (site 16, figs. 1 and 2);

3.) Gila Gravity Main Canal at Imperial Dam (USGS station; site 14a, figs. 1 and 2); and

4.) Mittry Lake Diversion at Imperial Dam (site 13, figs. 1 and 2).

The variance of estimate of the annual discharge at Colorado River above Imperial Dam was determined by adding together the variance of estimate of the annual discharge for each of the four stations listed above. The standard error of the annual discharge was then computed as the square root of the variance of estimate. The standard error of the annual discharge for 1995-99 ranged from 0.38 to 0.54 percent (table 6). 


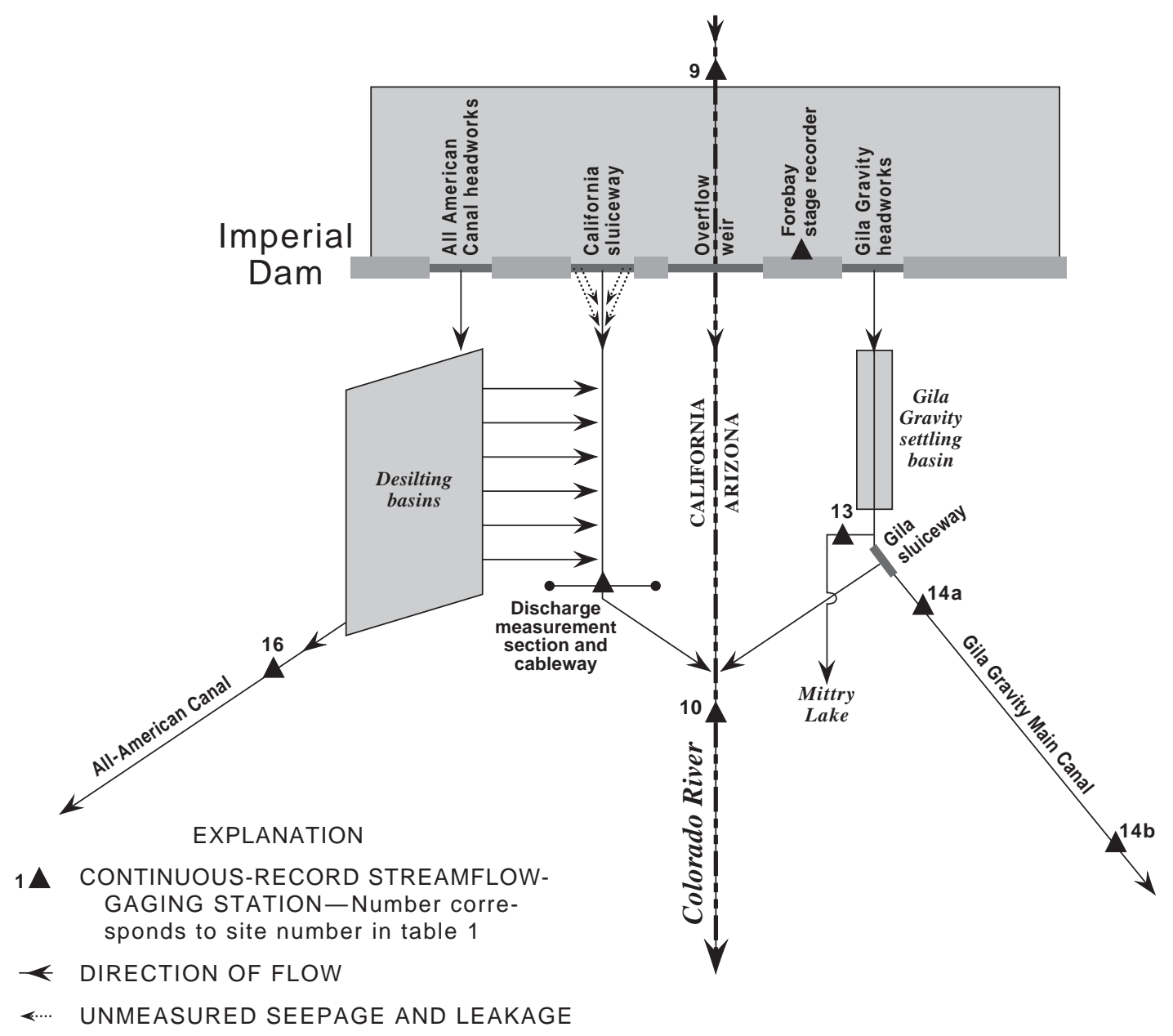

Figure 19. Streamflow-gaging stations used to compute discharge at Colorado River above Imperial Dam and at Colorado River below Imperial Dam.

Table 6. Summary of error-analysis results for the annual discharge at Colorado River above Imperial Dam

\begin{tabular}{|c|c|c|c|c|c|}
\hline \multicolumn{6}{|c|}{ Uncertainty in the annual discharge } \\
\hline & 1995 & 1996 & 1997 & 1998 & 1999 \\
\hline Annual discharge, acre-feet & $5,568,000$ & $6,065,000$ & $7,326,000$ & $9,045,000$ & $7,175,000$ \\
\hline $\begin{array}{l}\text { Variance of estimate of the annual } \\
\text { discharge, }(\text { acre-feet })^{2}\end{array}$ & $914,800,000$ & $910,900,000$ & $912,000,000$ & $1,165,000,000$ & $931,500,000$ \\
\hline $\begin{array}{l}\text { Standard error of the annual } \\
\text { discharge, acre-feet }\end{array}$ & 30,250 & 30,180 & 30,200 & 34,100 & 30,520 \\
\hline $\begin{array}{l}\text { Standard error of the annual } \\
\text { discharge, percent }\end{array}$ & 0.54 & 0.50 & 0.41 & 0.38 & 0.43 \\
\hline
\end{tabular}




\section{Colorado River below Imperial Dam}

The Colorado River below Imperial Dam streamflow-gaging station (site 10, figs. 1 and 2 ) is at Imperial Dam and is cooperatively operated by the USGS and the Imperial Irrigation District (IID). Streamflow for 1995-99 was computed as the sum of the discharge of:

1.) releases through the California sluiceway gates;

2.) leakage under Imperial Dam and seepage through closed California sluiceway gates;

3.) All-American Canal desilting-basin discharges;

4.) spill over Imperial Dam between the California and Gila sluiceways; and

5.) releases and seepage through the Gila sluiceway gates (fig. 19).

The California sluiceway consists of twelve 7 by $16 \mathrm{ft}$ radial gates. Discharge through the gates is free-fall and computed on the basis of the gate opening and the elevation head of the water flowing through the gate (measured as the difference between the forebay water-surface elevation and the elevation of the midpoint between the bottom of the gate and the gate sill). The forebay stage was monitored continuously by the USGS with a float-tape gage in a stilling well on the east end of the dam. Gate openings were indicated on dials for each gate at the dam; these readings were transmitted to the Imperial Dam control house, logged by personnel at the dam, and provided to the USGS for computing discharge. In addition to the releases through open gates of the California sluiceway some water seeps through the closed gates, and some water leaks under the dam.

Suspended sediment in the All-American Canal diversions is partially removed in desilting basins (fig. 19). As part of this process, water is discharged from the desilting basins (termed desilting basin discharges) to the Colorado River below Imperial Dam. The desilting-basin discharges were monitored by the IID and reported to the USGS.

The section of Imperial Dam between the California and Gila sluiceways consists of an overflow weir, and discharge was computed by using a theoretical weir rating and the forebay stage record. Excess water was almost always discharged through the California sluiceway rather than through the overflow weir. The Gila sluiceway has eight slide gates, and discharge was computed by the IID and provided to the USGS. Streamflow-computation records indicated that discharge through the Gila sluiceway and the overflow weir was negligible during the period of study (1995-99).

Discharge was measured by the USGS from a cableway about $0.7 \mathrm{mi}$ downstream from the California sluiceway (fig. 19) by using vertical-axis current meters. Discharge for these measurements includes the flow in the Colorado River below Imperial Dam that was from releases through open California sluiceway gates, seepage through closed gates and leakage under Imperial Dam, and desilting-basin discharges. For a given discharge measurement, the discharge through the California sluiceway gates was determined by subtracting the reported desilting-basin discharges and the estimated leakage under Imperial Dam and seepage through closed California sluiceway gates from the total measured discharge. USGS personnel established that the leakage under Imperial Dam and the seepage through the California sluiceway gates was about $50 \mathrm{ft}^{3} / \mathrm{s}$ by subtracting discharge for desilting-basin discharges from the total measured discharge for several measurements made while the California sluiceway gates were closed.

For the purpose of the error analysis, discharge for the Colorado River below Imperial Dam was considered to be the sum of the discharges for two stations: (1) desilting-basin discharges, seepage, and leakage, which consists of the discharge from the All-American Canal desilting basins, leakage under Imperial Dam, and seepage through closed California sluiceway gates, and (2) California sluiceway releases. Reported flows for the desilting-basin discharges, gate openings of the California sluiceway, forebay stage, and discharge measurements made from 1979 through 1999 were used in the error analysis. Discharge measurements for the Colorado River below Imperial Dam were assigned to one or the other station on the basis of whether all the California sluiceway gates were closed or not. 
By using 101 discharge measurements made from 1979 through 1999 with all the California sluiceway gates closed, an estimate was made for the uncertainty in the desilting-basin discharges, seepage, and leakage. A simple and unbiased discharge rating for computing desilting-basin discharges, seepage, and leakage was developed (table 7). Note that the constant in the discharge-rating equation (table 7), $55 \mathrm{ft}^{3} / \mathrm{s}$, indicates that the discharge rating used in practice (reported desilting-basin discharges plus $50 \mathrm{ft}^{3} / \mathrm{s}$ ) probably underestimates the true flow by $5 \mathrm{ft}^{3} / \mathrm{s}$. A theoretical semivariogram of the discharge-rating residuals was fit by nonlinear least squares (fig. 20). Measurement variance was determined from the empirical semivariogram. Application of the modified Moss and Gilroy method yielded estimates of the standard error of the annual discharge for 1995-99 that ranged from 7.65 to 13.8 percent (table 7). Note that because this rating is not shifted in practice, the effective number of discharge measurements per year is zero.

Table 7. Summary of error-analysis results for the annual discharge at Colorado River below Imperial Dam

[ $q_{r}$, discharge; $h_{1}$, forebay stage; $h_{g}$, gate-opening; $i$, gate number; $\mathrm{ft}^{3} / \mathrm{s}$, cubic feet per second]

\section{Summary of discharge-rating residuals by station}

\section{Desilting-basin discharges, seepage, and leakage}

Discharge-rating period

Discharge-rating equation

Number of discharge measurements

Average discharge for measurements, $\mathrm{ft}^{3} / \mathrm{s}$

Effective percent error for discharge measurements

Measurement variance, $\left(\mathrm{ft}^{3} / \mathrm{s}\right)^{2}$

Process variance, $\left(\mathrm{ft}^{3} / \mathrm{s}\right)^{2}$

One-day serial-correlation coefficient for discharge-rating residuals

$1 / 1 / 79$ to $12 / 31 / 99$ discharges

101

326

4.92

275

1,920

0.998

\section{California sluiceway releases}

$1 / 1 / 79$ to $12 / 31 / 99$

$q_{r}=92.4 \sum_{i=1}^{12} h_{g}(i) \times\left(h_{1}-63.00-0.5 h_{g}(i)\right)^{0.50}$

$q_{r}=55+$ the reported desilting-basin

99

6,000

2.50

44,900

89,400

0.996

\begin{tabular}{|c|c|c|c|c|c|}
\hline \multicolumn{6}{|c|}{ Uncertainty in the annual discharge } \\
\hline & 1995 & 1996 & 1997 & 1998 & 1999 \\
\hline \multicolumn{6}{|c|}{ Desilting-basin discharges, seepage, and leakage } \\
\hline Number of discharge measurements & 0 & 0 & 0 & 0 & 0 \\
\hline Annual discharge, acre-feet & 204,900 & 217,700 & 252,700 & 323,500 & 370,000 \\
\hline $\begin{array}{l}\text { Variance of estimate of the annual } \\
\text { discharge (acre-feet) })^{2}\end{array}$ & $800,400,000$ & $800,400,000$ & $800,400,000$ & $800,400,000$ & $800,400,000$ \\
\hline $\begin{array}{l}\text { Standard error of the annual } \\
\text { discharge, acre-feet }\end{array}$ & 28,300 & 28,300 & 28,300 & 28,300 & 28,300 \\
\hline $\begin{array}{l}\text { Standard error of the annual } \\
\text { discharge, percent }\end{array}$ & 13.81 & 13.0 & 11.20 & 8.75 & 7.65 \\
\hline
\end{tabular}


Table 7. Summary of error-analysis results for the annual discharge at Colorado River above Imperial Dam—Continued

\begin{tabular}{|c|c|c|c|c|c|}
\hline \multicolumn{6}{|c|}{ Uncertainty in the annual discharge-Continued } \\
\hline & 1995 & 1996 & 1997 & 1998 & 1999 \\
\hline \multicolumn{6}{|c|}{ California sluiceway releases } \\
\hline Number of discharge measurements & 2 & 1 & 2 & 6 & 1 \\
\hline Annual discharge, acre-feet & 29,300 & 13,160 & 119,900 & $1,207,000$ & 168,300 \\
\hline $\begin{array}{l}\text { Variance of estimate of the annual } \\
\quad \text { discharge, }(\text { acre-feet })^{2}\end{array}$ & 391,500 & 140,700 & $6,559,000$ & $245,400,000$ & $23,020,000$ \\
\hline $\begin{array}{l}\text { Standard error of the annual } \\
\text { discharge, acre-feet }\end{array}$ & 626 & 375 & 2,560 & 15,950 & 4,800 \\
\hline $\begin{array}{l}\text { Standard error of the annual } \\
\text { discharge, percent }\end{array}$ & 2.14 & 2.85 & 2.14 & 1.32 & 2.85 \\
\hline \multicolumn{6}{|c|}{ Total flow at the Colorado River below Imperial Dam } \\
\hline Annual discharge, acre-feet & 234,200 & 230,830 & 372,600 & $1,531,000$ & 538,300 \\
\hline $\begin{array}{l}\text { Variance of estimate of the annual } \\
\quad \text { discharge, }(\text { acre-feet })^{2}\end{array}$ & $800,700,000$ & $800,500,000$ & $806,900,000$ & $800,400,000$ & $823,400,000$ \\
\hline $\begin{array}{l}\text { Standard error of the annual } \\
\text { discharge, acre-feet }\end{array}$ & 28,300 & 28,300 & 28,400 & 32,500 & 28,700 \\
\hline $\begin{array}{l}\text { Standard error of the annual } \\
\text { discharge, percent }\end{array}$ & 12.08 & 12.26 & 7.62 & 2.12 & 5.33 \\
\hline
\end{tabular}

The uncertainty in flow through the California sluiceway gates was determined from 99 discharge measurements made from 1979 through 1999 while one or more gates was open. An unbiased discharge-rating equation was developed on the basis of the forebay stage, gate-sill elevation, and gate opening widths for the 16 sluiceway gates (table 7). A theoretical semivariogram of the discharge-rating residuals was fit by nonlinear least squares (fig. 20). Measurement variance was determined from the empirical semivariogram. The modified Moss and Gilroy method assumes that the discharge for the measurements is representative of the computed discharges throughout the year. The average discharge for the 99 measurements $\left(6,050 \mathrm{ft}^{3} / \mathrm{s}\right)$ was much larger than the average discharge that was released through the California sluiceway for 1995-99 $\left(876 \mathrm{ft}^{3} / \mathrm{s}\right)$. To account for this discrepancy in discharges, a percent error was determined by dividing the results from the modified Moss and Gilroy method by the mean measured discharge. The standard error of the annual discharge was determined by multiplying the annual discharge by this percent error, and the variance of estimate of the annual discharge was determined by squaring the standard error. The standard error of the annual discharge for 1995-99 ranged from 1.32 to 2.85 percent (table 7 ).

The variance of estimate of the annual discharge at the Colorado River below Imperial Dam (site 10, figs. 1 and 2) was determined by adding together the variance of estimate of the annual discharge from each of the two stations. The standard error of the annual discharge at the Colorado River below Imperial Dam, 1995-99, ranged from 2.12 to 12.26 percent (table 7). 

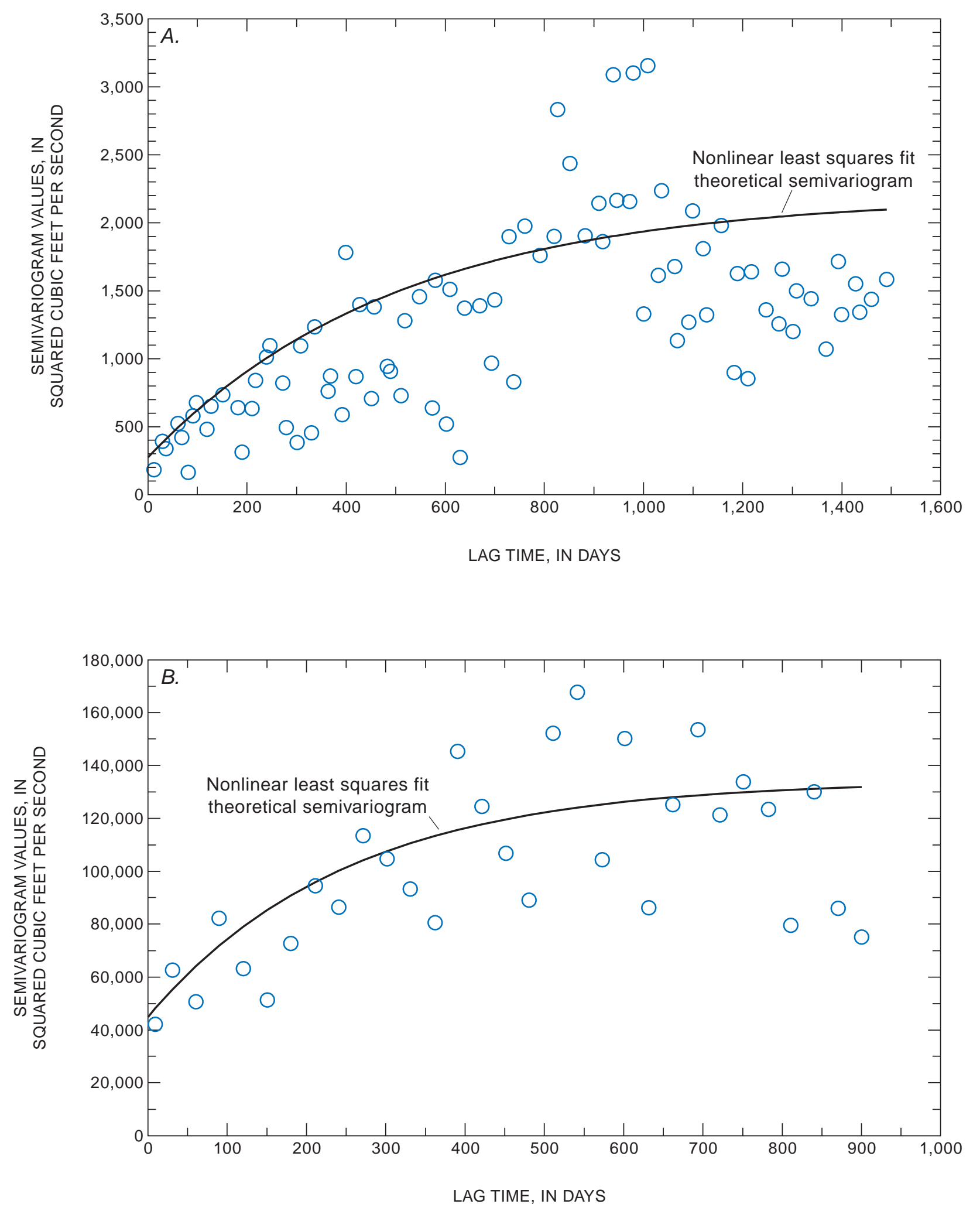

Figure 20. Semivariograms of discharge-rating residuals for streamflow-gaging stations used to compute discharge at Colorado River below Imperial Dam. A, Desilting-basin discharges, seepage, and leakage from the California sluiceway, January 1, 1979, to December 31, 1999. B, California sluiceway releases, January 1, 1979, to December 31, 1999. Blue circles represent the empirical semivariogram. 


\section{Gila River near Dome}

The Gila River near Dome streamflow-gaging station (site 11, figs. 1 and 2) is operated by the USGS and is approximately $12 \mathrm{mi}$ upstream from the mouth and $0.5 \mathrm{mi}$ downstream from the U.S. Highway 95 bridge. Streamflow for 1995-99 was computed on the basis of a stage-discharge relation. Stage was monitored continuously by using a float gage in a stilling well. Wadable discharge measurements typically were made with vertical-axis current meters near the U.S. Highway 95 bridge. The distance between the stilling well and the measuring section was long and may have had undesirable streamflow gains or losses; however, no closer measuring sections were available because the channel in this reach was deep and (or) wide, which caused velocities to be slower than recommended for vertical-axis current meters. High flows were measured by using vertical-axis current meters, either at the U.S. Highway 95 bridge or at the McPhaul bridge, about 500 feet downstream from the stilling well.

Streamflow was atypically high at this station from April 1995 through September 1995 because of gradual releases of impounded upper basin winter runoff from Painted Rock Reservoir. Channel changes during this period of high flow required development of stage-discharge ratings for the time period before the high flows, during the high flows, and after the high flows. Altogether, five time-dependent discharge ratings were developed for the period 1995-99 on the basis of stage and discharge measurements (table 8). Theoretical semivariograms of the discharge-rating residuals were fit manually for each of the five discharge-rating periods (fig. 21). Measurement variance could not be determined clearly from the empirical semivariograms, so it was determined on the basis of $\alpha_{i}$ and equation 8 . The effective percent error for discharge measurements for all but the second period was relatively large compared to that of other stations because the measuring section typically had slow velocities, shallow depths, and a sandy streambed. The smaller effective percent error for discharge measurements for the second period, 3.11 percent, was reasonable because velocities were faster and depths were deeper for measurements made during this period of high streamflow. Application of the modified Moss and Gilroy method yielded estimates of the standard error of the annual discharge for 1995-99 that ranged from 1.46 to 6.02 percent (table 8). For years with two or more discharge-rating periods, the variance of estimate of the annual discharge was determined by using equation 15 to combine the variance of estimate of the discharge that accumulated during each discharge-rating period.

\section{Colorado River at the Northerly International Boundary with Mexico}

The Colorado River at the NIB streamflow-gaging station (site 12, figs. 1 and 2) is about 1 mi upstream from Morelos Dam and is operated by the U.S. Section of the IBWC. Streamflow for 1995-99 was computed on the basis of a stage-discharge relation. Discharge was measured from a cableway by using vertical-axis current meters, and stage was monitored continuously with a float in a stilling well. About 200 discharge measurements were made each year, of which about one third were made by the Mexico Section of the IBWC, and about two thirds were made by the U.S. Section of the IBWC. The USGS also made a few discharge measurements each year. The U.S. Section of the IBWC computed discharge records on the basis of stage and discharge measurements made by all three agencies and provided them to the USGS for publishing in the annual data book (such as Tadayon and others, 2000) under station number 09522000. 
Table 8. Summary of error-analysis results for the annual discharge at Gila River near Dome [ $q_{r}$, discharge; $h$, gage height; $t$, time in decimal years; $\mathrm{ft}^{3} / \mathrm{s}$, cubic feet per second]

\begin{tabular}{|c|c|c|c|c|c|}
\hline \multicolumn{6}{|c|}{ Summary of discharge-rating residuals by discharge-rating period } \\
\hline Discharge-rating period & $\begin{array}{c}1 \\
6 / 28 / 94 \text { to } \\
4 / 5 / 95\end{array}$ & $\begin{array}{c}2 \\
4 / 6 / 95 \text { to } \\
9 / 25 / 95\end{array}$ & $\begin{array}{c}3 \\
9 / 26 / 95 \text { to } \\
12 / 31 / 96\end{array}$ & $\begin{array}{c}4 \\
1 / 1 / 97 \text { to } \\
7 / 30 / 98\end{array}$ & $\begin{array}{c}5 \\
7 / 31 / 98 \text { to } \\
12 / 31 / 99\end{array}$ \\
\hline $\begin{array}{l}\text { Number of discharge } \\
\text { measurements }\end{array}$ & 10 & 12 & 15 & 22 & 16 \\
\hline $\begin{array}{l}\text { Average discharge for } \\
\text { measurements, } \mathrm{ft}^{3} / \mathrm{s}\end{array}$ & 24.2 & 1,590 & 17.0 & 17.0 & 6.85 \\
\hline $\begin{array}{l}\text { Effective percent error for } \\
\text { discharge measurements }\end{array}$ & 5.50 & .11 & 4.45 & 4.50 & 5.13 \\
\hline $\begin{array}{l}\text { Measurement variance, } \\
\left(\mathrm{ft}^{3} / \mathrm{s}\right)^{2}\end{array}$ & 2.71 & 3,370 & 0.93 & 0.92 & 0.43 \\
\hline Process variance, $\left(\mathrm{ft}^{3} / \mathrm{s}\right)^{2}$ & 2.09 & 8,880 & 8.55 & 5.34 & 0.82 \\
\hline $\begin{array}{l}\text { One-day serial-correlation } \\
\text { coefficient for discharge- } \\
\text { rating residuals }\end{array}$ & 0.985 & 0.971 & 0.980 & 0.952 & 0.980 \\
\hline Discharge-rating period & \multicolumn{4}{|c|}{ Discharge-rating equation } & \\
\hline 1 & \multicolumn{5}{|c|}{$q_{r}=16.8(h-11.33-0.192(t-1995))^{3.17}$} \\
\hline 2 & \multicolumn{5}{|c|}{$q_{r}=185.9(h-13.03+1.14(t-1995))^{1.56}$} \\
\hline 3 & \multicolumn{5}{|c|}{$q_{r}=13.2(h-10.38-0.492(t-1995))^{2.47}$} \\
\hline 4 & \multicolumn{5}{|c|}{$q_{r}=14.34(h-9.74-0.607(t-1995)+0.566 \cos (2 \pi t)+0.081 \sin (2 \pi t))$} \\
\hline 5 & \multicolumn{5}{|c|}{$q_{r}=7.02(h-13.77-0.433(t-1995)+0.794 \cos (2 \pi t)+0.374 \sin (2 \pi t))$} \\
\hline \multicolumn{6}{|c|}{ Uncertainty in the annual discharge } \\
\hline & 1995 & 1996 & 1997 & 1998 & 1999 \\
\hline $\begin{array}{l}\text { Number of discharge } \\
\text { measurements }\end{array}$ & 18 & 12 & 14 & 12 & 13 \\
\hline Annual discharge, acre-feet & 527,800 & 9,410 & 16,800 & 7,960 & 7,020 \\
\hline $\begin{array}{l}\text { Variance of estimate of the } \\
\text { annual discharge } \\
(\text { acre-feet })^{2}\end{array}$ & $169,300,000$ & 64,520 & 60,170 & 132,000 & 178,200 \\
\hline $\begin{array}{l}\text { Standard error of the annual } \\
\text { discharge, acre-feet }\end{array}$ & 13,010 & 254 & 245 & 363 & 422 \\
\hline $\begin{array}{l}\text { Standard error of the annual } \\
\text { discharge, percent }\end{array}$ & 2.47 & 2.70 & 1.46 & 4.56 & 6.02 \\
\hline
\end{tabular}




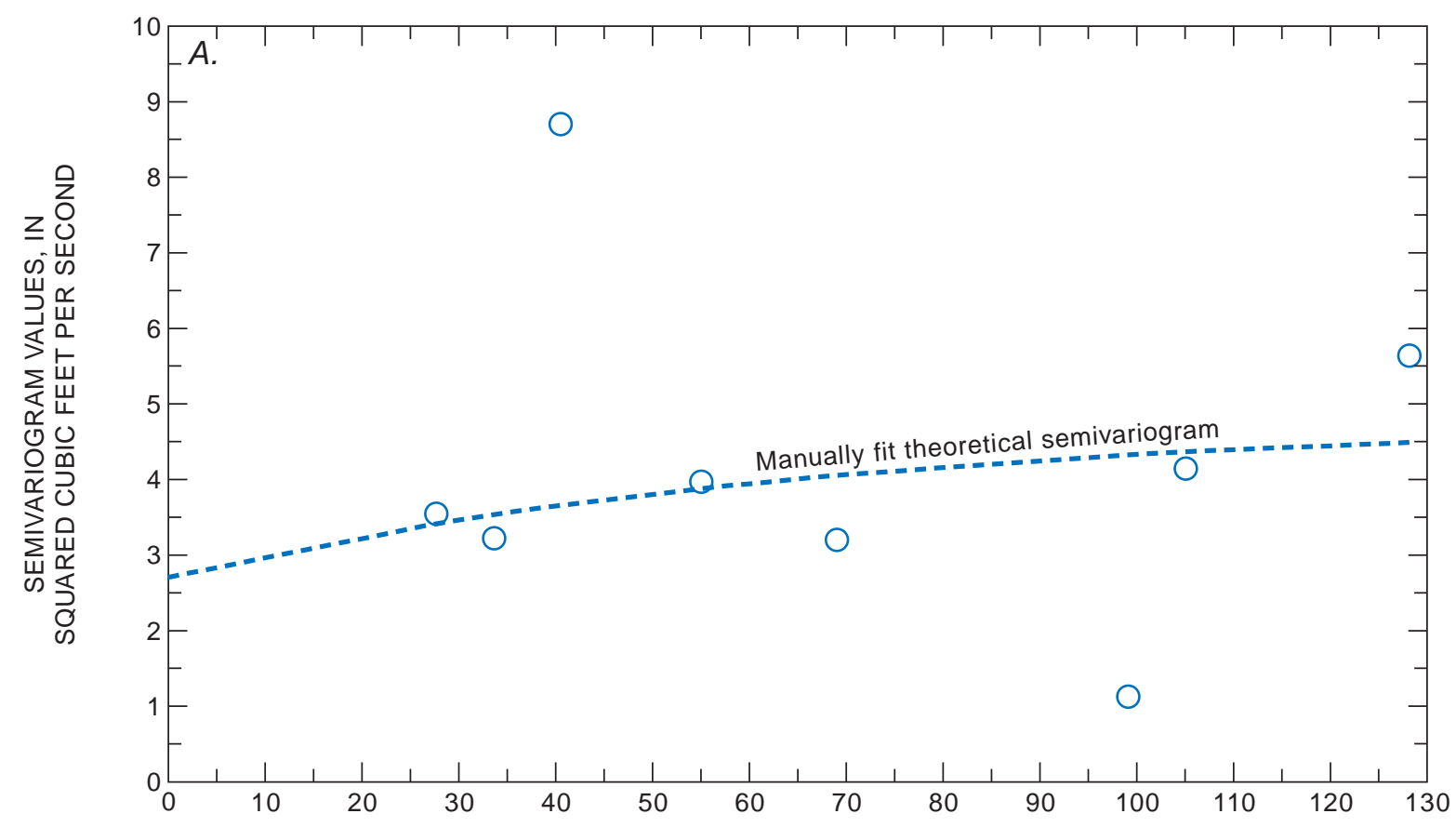

LAG TIME, IN DAYS

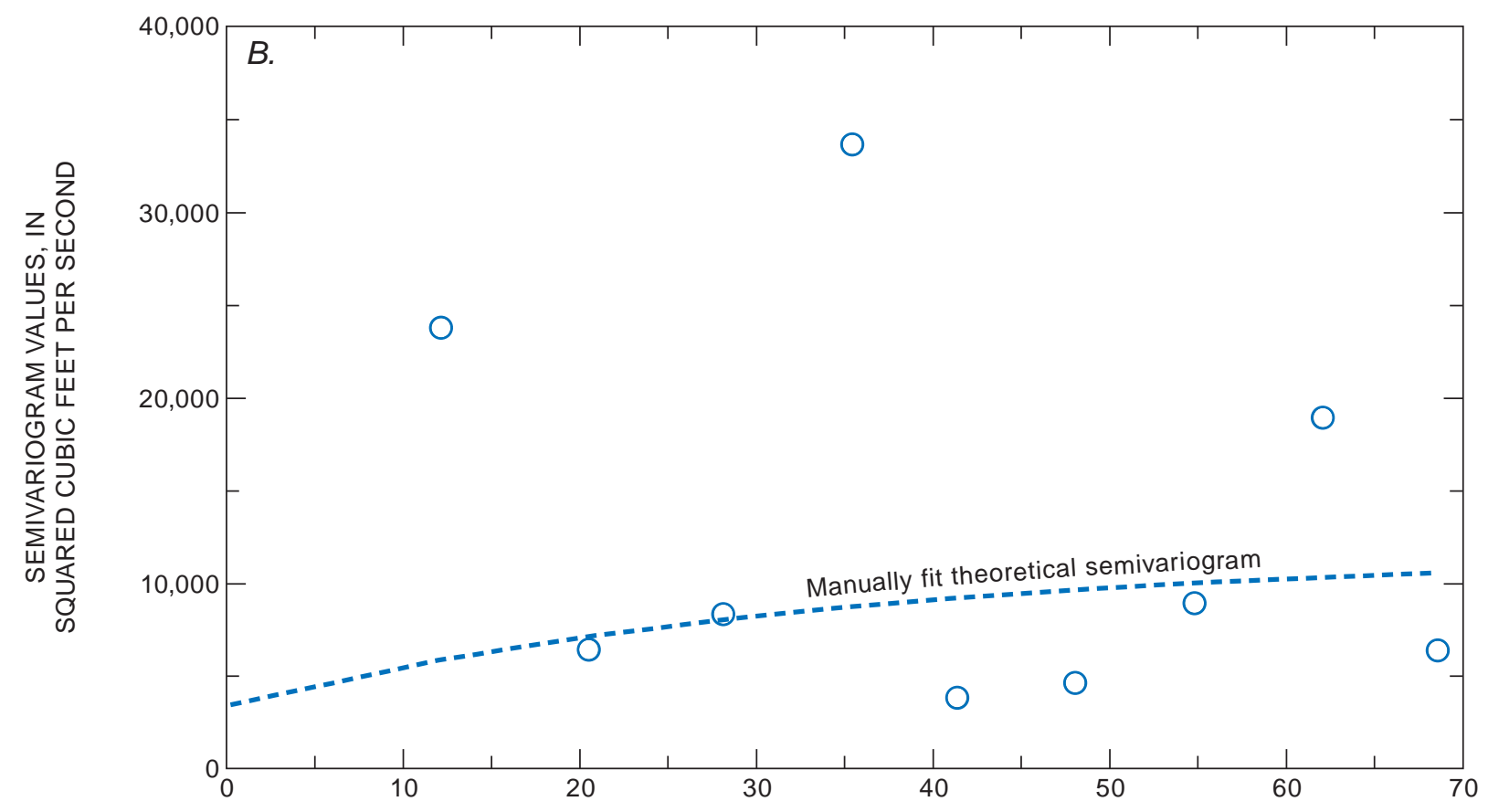

LAG TIME, IN DAYS

Figure 21. Semivariograms of discharge-rating residuals for Gila River near Dome. A, June 28, 1994, to April 5, 1995. B, April 6, 1995, to September 25, 1995. C, September 26, 1995, to December 31, 1996. D, January 1, 1997, to July 30, 1998. $E$, July 31, 1998, to December 31, 1999. Blue circles represent the empirical semivariogram. 

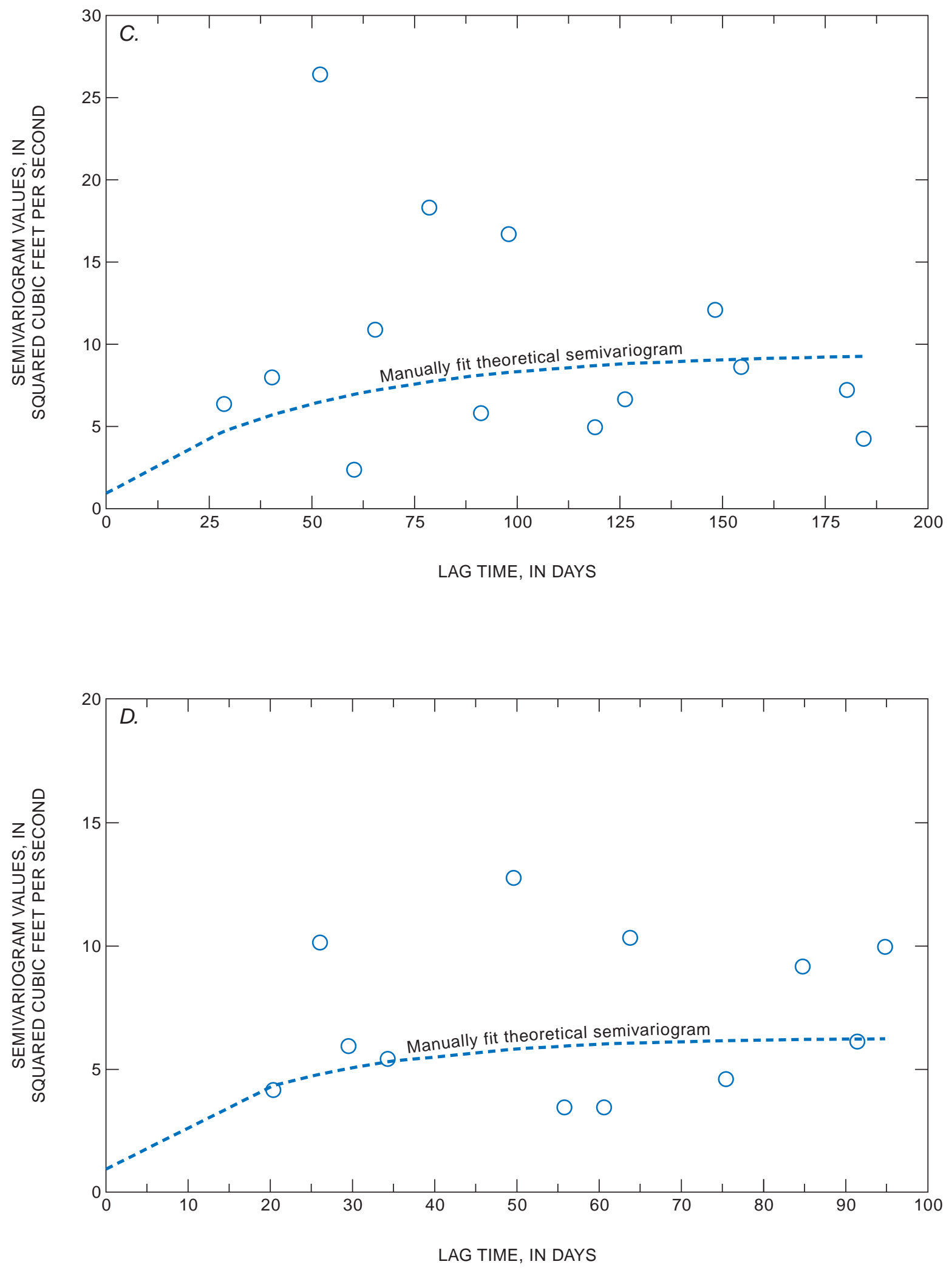

Figure 21. Continued. 


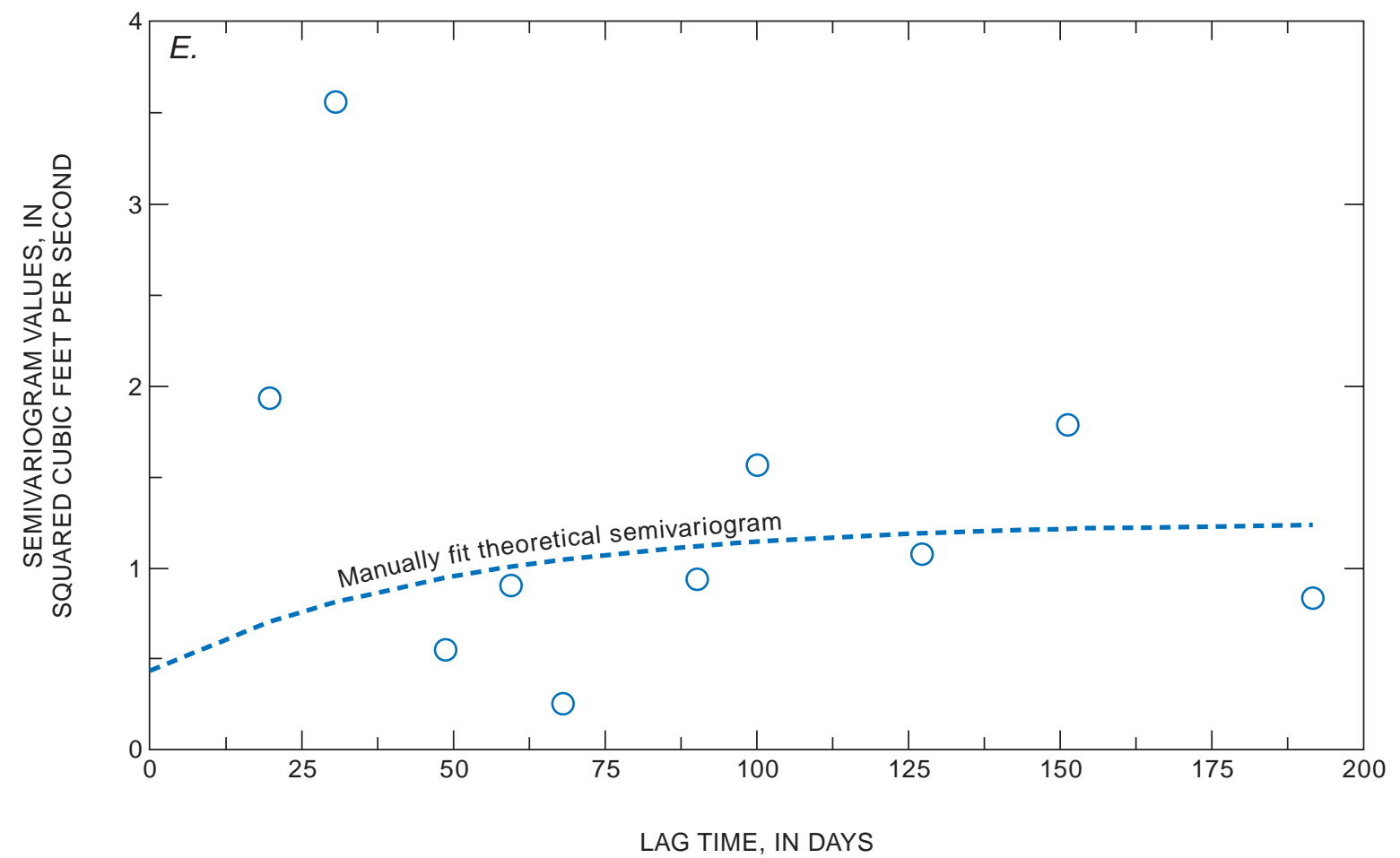

Figure 21. Continued.

High flows and channel dredging altered channel conditions and changed the stage-discharge relation at the station several times. An analysis of residuals from a stage-discharge rating that was developed on the basis of 981 measurements made during 1995-99 indicated that there were 17 distinct discharge-rating periods (fig. 7). The time period for the stage-discharge rating, number of measurements used to develop the stage-discharge rating, and the stage-discharge ratings are listed in table 9. Theoretical semivariograms of the discharge-rating residuals were fit by using nonlinear least squares for nine of the discharge-rating periods (fig. 22). Values of $\alpha_{e}$ estimated from the empirical semivariograms for these nine periods ranged from 2.55 to 4.51 percent, which qualitatively appeared reasonable. These values, however, were not compared to values of $\alpha_{e}$ determined on the basis of equation 14 and measurement variance determined from equation 8 and $\alpha_{i}$ because of the large number of measurements and the lack of information in an electronic format about the measuring conditions during each measurement. For the remaining eight discharge-rating periods, theoretical semivariograms of the discharge-rating residuals were fit manually (fig. 22). Measurement variance could not be determined clearly for these eight discharge-rating periods, so it was determined on the basis of equation 13 and $\alpha_{e}$ for the other nine periods. Application of the modified Moss and Gilroy method yielded estimates of the standard error of the annual discharge for 1995-99 that ranged from 0.19 to 1.76 percent (table 9). For years with two or more discharge-rating periods, the variance of estimate of the annual discharge was determined by using equation 15 to combine the variance of estimate of the discharge that accumulated during each discharge-rating period. 
Table 9. Summary of error-analysis results for the annual discharge at Colorado River at the northerly international boundary with Mexico [ $q_{r}$, discharge; $h$, gage height; $t$, time in decimal years; $\mathrm{ft}^{3} / \mathrm{s}$, cubic feet per second]

\begin{tabular}{|c|c|c|c|c|c|c|}
\hline \multicolumn{7}{|c|}{ Summary of discharge-rating residuals by discharge-rating period } \\
\hline $\begin{array}{l}\text { Discharge } \\
\text { rating period }\end{array}$ & $\begin{array}{c}1 \\
1 / 1 / 95 \text { to } \\
2 / 28 / 95\end{array}$ & $\begin{array}{c}2 \\
3 / 1 / 95 \text { to } \\
4 / 19 / 95\end{array}$ & $\begin{array}{c}3 \\
4 / 20 / 95 \text { to } \\
5 / 15 / 95\end{array}$ & $\begin{array}{c}4 \\
5 / 16 / 95 \text { to } \\
6 / 15 / 95\end{array}$ & $\begin{array}{c}5 \\
6 / 16 / 95 \\
7 / 28 / 95\end{array}$ & $\begin{array}{c}6 \\
7 / 29 / 95 \text { to } \\
1 / 16 / 97\end{array}$ \\
\hline $\begin{array}{l}\text { Number of } \\
\text { measurements }\end{array}$ & 38 & 34 & 16 & 14 & 20 & 259 \\
\hline $\begin{array}{l}\text { Average discharge } \\
\text { for measurements, } \\
\mathrm{ft}^{3} / \mathrm{s}\end{array}$ & 2,439 & 2,770 &, 576 & 2,920 & 3,314 & 1,850 \\
\hline $\begin{array}{l}\text { Effective percent } \\
\text { error for discharge } \\
\text { measurements }\end{array}$ & 3.10 & 2.89 & 3.10 & 2.16 & 3.16 & 2.37 \\
\hline $\begin{array}{l}\text { Measurement } \\
\quad \text { variance, }\left(\mathrm{ft}^{3} / \mathrm{s}\right)^{2}\end{array}$ & 5,970 & 4,850 & 6,160 & 4,000 & 10,600 & 2,230 \\
\hline $\begin{array}{l}\text { Process variance, } \\
\qquad\left(\mathrm{ft}^{3} / \mathrm{s}\right)^{2}\end{array}$ & 46,000 & 22,200 & 23,800 & 8,880 & 7,310 & 6,350 \\
\hline $\begin{array}{l}\text { One-day serial- } \\
\text { correlation } \\
\text { coefficient for } \\
\text { discharge-rating } \\
\text { residuals }\end{array}$ & 0.678 & 0.678 & 0.715 & 0.753 & 0.828 & 0.952 \\
\hline $\begin{array}{c}\text { Discharge-rating } \\
\text { period }\end{array}$ & $\begin{array}{c}7 \\
1 / 17 / 97 \text { to } \\
2 / 12 / 97\end{array}$ & $\begin{array}{c}8 \\
2 / 13 / 97 \text { to } \\
3 / 25 / 97\end{array}$ & $\begin{array}{c}9 \\
3 / 26 / 97 \text { to } \\
7 / 21 / 97\end{array}$ & $\begin{array}{c}10 \\
7 / 22 / 97 \text { to } \\
10 / 20 / 97\end{array}$ & $\begin{array}{c}11 \\
10 / 21 / 97 \text { to } \\
12 / 31 / 97\end{array}$ & $\begin{array}{c}12 \\
1 / 01 / 98 \text { to } \\
2 / 24 / 98\end{array}$ \\
\hline $\begin{array}{l}\text { Number of } \\
\text { measurements }\end{array}$ & 17 & 17 & 57 & 65 & 37 & 36 \\
\hline $\begin{array}{l}\text { Average discharge } \\
\text { for measurements, } \\
\mathrm{ft}^{3} / \mathrm{s}\end{array}$ & 6,494 & 5,422 & 3,102 & 5,119 & 2,006 & 11,410 \\
\hline $\begin{array}{l}\text { Effective percent } \\
\text { error for discharge } \\
\text { measurements }\end{array}$ & 3.10 & 3.64 & 2.75 & 3.10 & 2.91 & 2.35 \\
\hline $\begin{array}{l}\text { Measurement } \\
\text { variance, }\left(\mathrm{ft}^{3} / \mathrm{s}\right)^{2}\end{array}$ & 45,022 & 40,800 & 7,560 & 29,100 & 3,490 & 74,800 \\
\hline $\begin{array}{l}\text { Process variance, } \\
\qquad\left(\mathrm{ft}^{3} / \mathrm{s}\right)^{2}\end{array}$ & 182,000 & 31,300 & 2,830 & 315,000 & 18,000 & 133,400 \\
\hline $\begin{array}{l}\text { One-day serial- } \\
\text { correlation } \\
\text { coefficient for } \\
\text { discharge-rating } \\
\text { residuals }\end{array}$ & 0.757 & 0.759 & 0.936 & 0.503 & 0.666 & 0.821 \\
\hline
\end{tabular}


Table 9. Summary of error-analysis results for the annual discharge at Colorado River at the northerly international boundary with Mexico-Continued

\begin{tabular}{|c|c|c|c|c|c|}
\hline $\begin{array}{c}\text { Discharge-rating } \\
\text { period }\end{array}$ & $\begin{array}{c}13 \\
2 / 25 / 98 \text { to } \\
5 / 29 / 98\end{array}$ & $\begin{array}{c}14 \\
5 / 30 / 98 \text { to } \\
9 / 3 / 98\end{array}$ & $\begin{array}{c}15 \\
9 / 4 / 98 \text { to } \\
1 / 19 / 99\end{array}$ & $\begin{array}{c}16 \\
1 / 20 / 99 \text { to } \\
9 / 2 / 99\end{array}$ & $\begin{array}{c}17 \\
9 / 3 / 99 \text { to } \\
12 / 31 / 99\end{array}$ \\
\hline $\begin{array}{l}\text { Number of } \\
\text { measurements }\end{array}$ & 62 & 51 & 64 & 123 & 71 \\
\hline $\begin{array}{l}\text { Average discharge } \\
\text { for } \\
\text { measurements, } \\
\mathrm{ft}^{3} / \mathrm{s}\end{array}$ & 5,723 & 2,942 & 7,037 & 2,800 & 4,391 \\
\hline $\begin{array}{l}\text { Effective percent } \\
\text { error for } \\
\text { discharge } \\
\text { measurements }\end{array}$ & 4.03 & 2.34 & 3.33 & 2.77 & 3.05 \\
\hline $\begin{array}{l}\text { Measurement } \\
\quad \text { variance, }\left(\mathrm{ft}^{3} / \mathrm{s}\right)^{2}\end{array}$ & 66,600 & 4,990 & 65,500 & 6,370 & 19,800 \\
\hline $\begin{array}{l}\text { Process variance, } \\
\qquad\left(\mathrm{ft}^{3} / \mathrm{s}\right)^{2}\end{array}$ & 208,000 & 3,740 & 413,000 & 13,300 & 445,000 \\
\hline $\begin{array}{l}\text { One-day serial- } \\
\text { correlation } \\
\text { coefficient for } \\
\text { discharge-rating } \\
\text { residuals }\end{array}$ & 0.665 & 0.818 & 0.968 & 0.901 & 0.830 \\
\hline $\begin{array}{c}\text { Discharge-rating } \\
\text { period }\end{array}$ & \multicolumn{5}{|c|}{ Discharge-rating equation } \\
\hline 1 & \multicolumn{5}{|c|}{$q_{r}=349.5(h-104.62+30.67(t-1995))$} \\
\hline 2 & \multicolumn{5}{|c|}{$q_{r}=375.3(h-99.28-3.43(t-1995))$} \\
\hline 3 & \multicolumn{5}{|c|}{$q_{r}=904.3(h-101.87-2.33(t-1995))$} \\
\hline 4 & \multicolumn{5}{|c|}{$q_{r}=169.7(h-26.60+51.15 \cos (2 \pi t)-40.90 \sin (2 \pi t))$} \\
\hline 5 & \multicolumn{5}{|c|}{$q_{r}=343.4(h-97.95+1.11(t-1995))$} \\
\hline 6 & \multicolumn{5}{|c|}{$q_{r}=719.3(h-103.35+0.98(t-1995)-0.361 \cos (2 \pi t)+0.134 \sin (2 \pi t))$} \\
\hline 7 & \multicolumn{5}{|c|}{$q_{r}=615.1(h-98.38-1.63(t-1995))$} \\
\hline
\end{tabular}

\section{Discharge-rating} period

$8 \quad q_{r}=686.6(h-142.53+18.80(t-1995))$

$9 \quad q_{r}=683.2(h-99.64-0.43(t-1995))$

10

$$
q_{r}=494.9(h-70.41-11.38(t-1995))
$$


Table 9. Summary of error-analysis results for the annual discharge at Colorado River at the northerly international boundary with Mexico-Continued

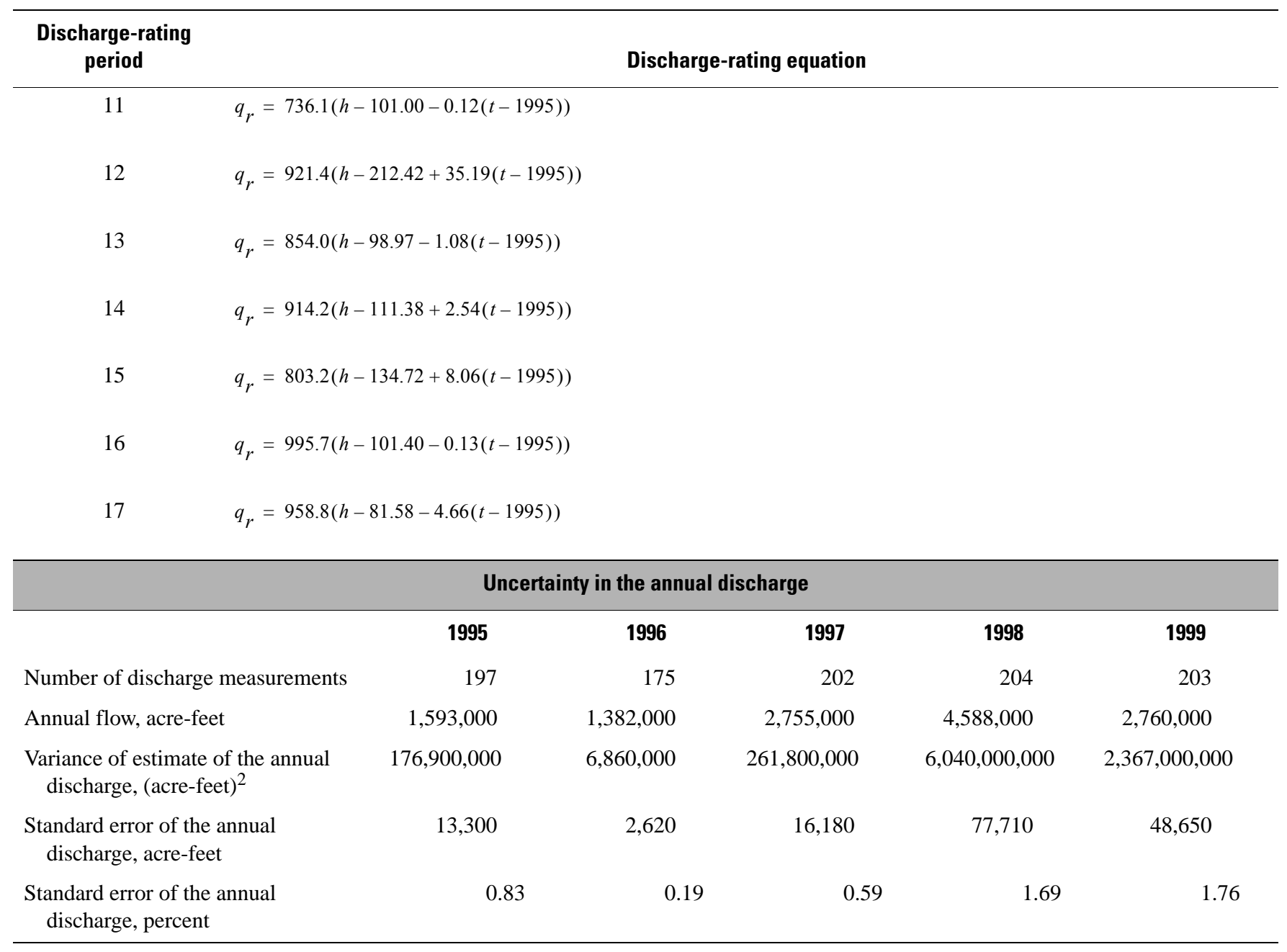



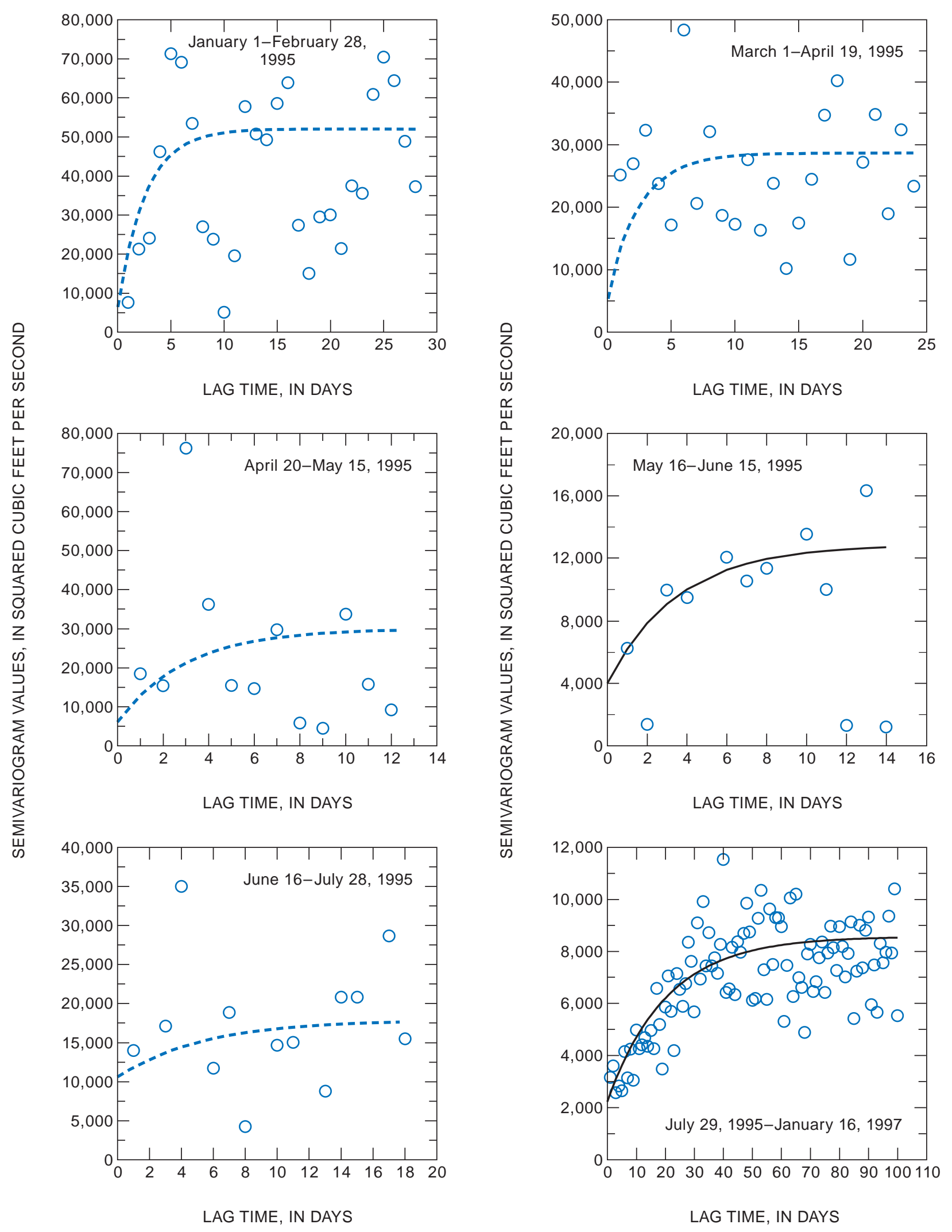


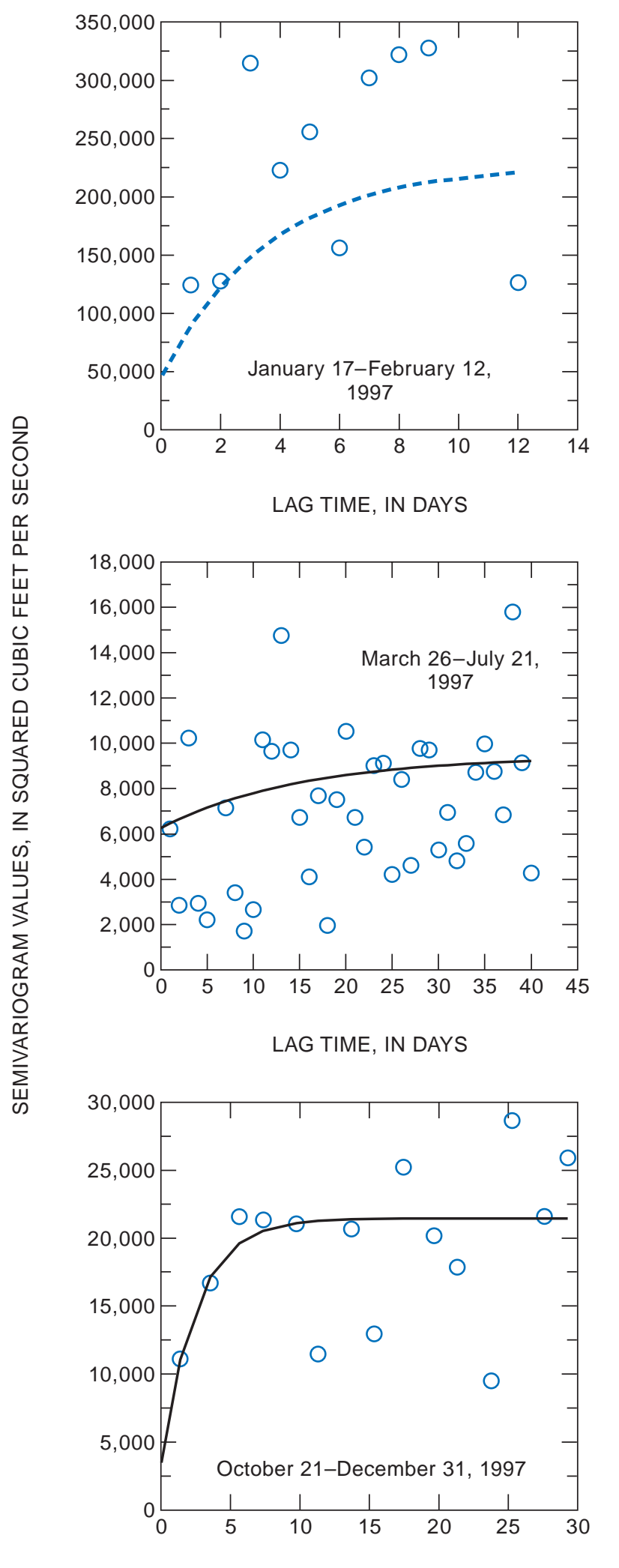

LAG TIME, IN DAYS

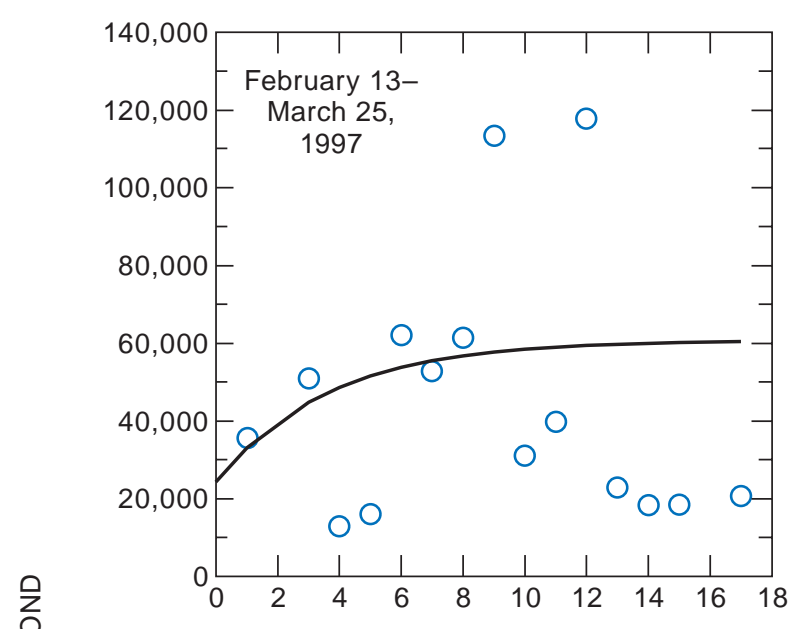

LAG TIME, IN DAYS

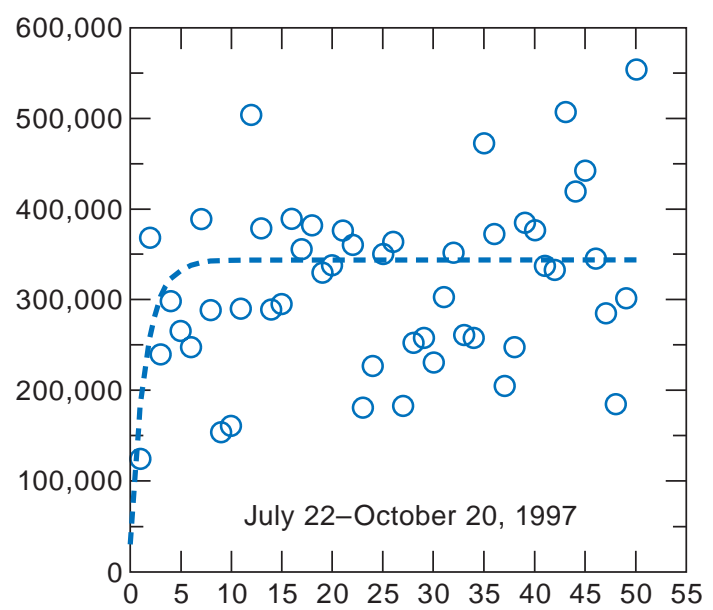

LAG TIME, IN DAYS

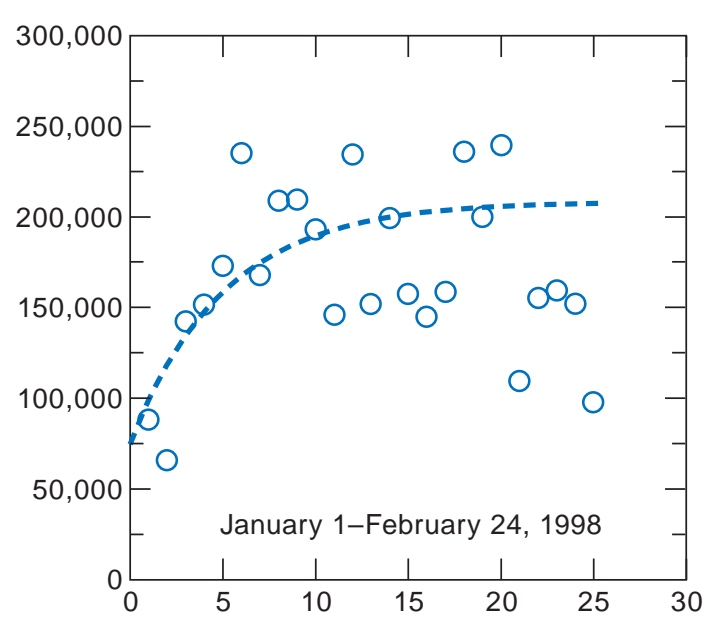

LAG TIME, IN DAYS

Figure 22. Continued. 

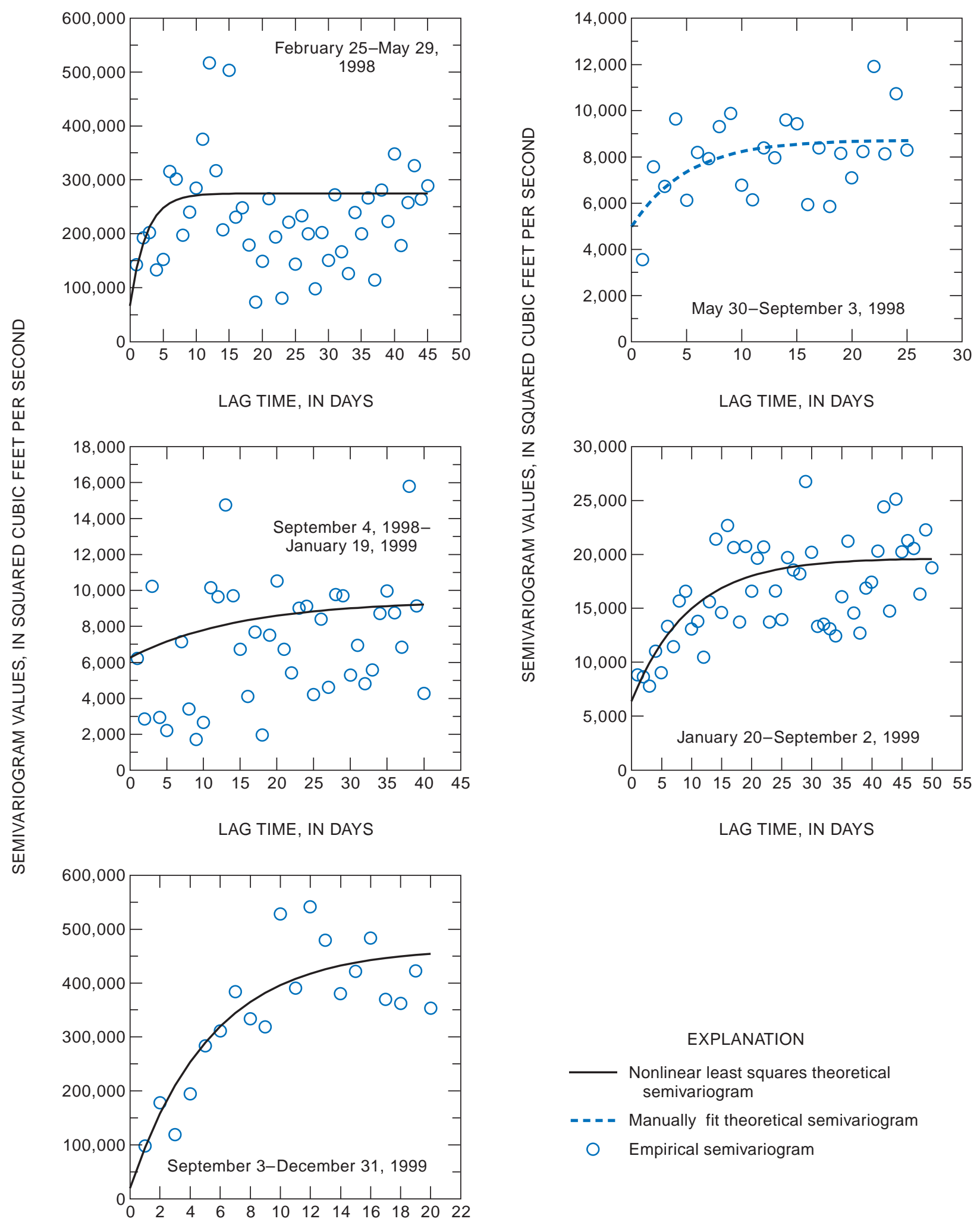

LAG TIME, IN DAYS

Figure 22. Continued. 


\section{Mittry Lake Diversion at Imperial Dam}

The Mittry Lake Diversion at Imperial Dam streamflow-gaging station (site 13, figs. 1 and 2) is near the downstream end of the Gila Gravity settling basin at Imperial Dam (fig. 19) and is operated cooperatively by the USGS and IID. The diversion to Mittry Lake is withdrawn from the Gila Gravity settling basin and transported through a 3-foot diameter pipe into a V-shaped concrete canal. A sparling meter was in a concrete box at the point of diversion and measured discharge volumes for 1995-99. The sparling meter dial indicates the volume of water that has been diverted since the meter was installed. The IID recorded sparling meter readings on a monthly basis and whenever the diversion discharge was changed; a log of these readings was furnished to the USGS for computing daily discharges. Daily discharges were computed by dividing the difference of two consecutive sparling meter readings by the time between the sparling meter readings. These discharge values were corrected by applying a shift that was determined on the basis of periodic discharge measurements made at the canal by using vertical-axis current meters. An unbiased rating was developed on the basis of 13 sparling-meter and discharge measurements made from 1995 through 1999 to convert sparling-meter readings to discharges (table 10). A theoretical semivariogram of the discharge-rating residuals was fit manually (fig. 23). The estimate for measurement variance was subjective because it could not be clearly determined from the semivariogram and because measurement variance determined on the basis of equation 8 and $\alpha_{i}$ was greater than the variance of the residuals. Application of the modified Moss and Gilroy method yielded estimates of the standard error of the annual discharge for 1995-99 that ranged from 0.93 to 1.84 percent (table 10).

Table 10. Summary of error-analysis results for the annual discharge at Mittry Lake Diversion at Imperial Dam

$\left[q_{r}\right.$, discharge; $s$, sparling meter dial reading; $t$, time; $\mathrm{ft}^{3} / \mathrm{s}$, cubic feet per second]

\begin{tabular}{|c|c|c|c|c|c|}
\hline \multicolumn{6}{|c|}{ Summary of discharge-rating residuals } \\
\hline Discharge-rating period & \multicolumn{5}{|c|}{$1 / 1 / 95$ to $12 / 31 / 95$} \\
\hline \multirow[t]{3}{*}{ Discharge-rating equation } & \multicolumn{5}{|c|}{$q_{r}=0.886 \times q_{\text {sparling }}$} \\
\hline & \multicolumn{5}{|l|}{ where: } \\
\hline & \multicolumn{5}{|c|}{$q_{\text {sparling }}=\frac{S_{2}-S_{1}}{t_{2}-t_{1}}$} \\
\hline Number of measurements & \multicolumn{5}{|l|}{13} \\
\hline $\begin{array}{l}\text { Average discharge for measurements, } \\
\mathrm{ft}^{3} / \mathrm{s}\end{array}$ & \multicolumn{5}{|l|}{14.3} \\
\hline $\begin{array}{l}\text { Effective percent error for discharge } \\
\text { measurements }\end{array}$ & \multicolumn{5}{|l|}{2.21} \\
\hline Measurement variance, $\left(\mathrm{ft}^{3} / \mathrm{s}\right)^{2}$ & \multicolumn{5}{|l|}{0.10} \\
\hline Process variance, $\left(\mathrm{ft}^{3} / \mathrm{s}\right)^{2}$ & \multicolumn{5}{|l|}{0.20} \\
\hline One-day serial-correlation coefficient for & \multicolumn{5}{|l|}{0.990} \\
\hline \multicolumn{6}{|c|}{ Uncertainty in the annual discharge } \\
\hline & 1995 & 1996 & 1997 & 1998 & 1999 \\
\hline Number of discharge measurements & 5 & 3 & 3 & 2 & 0 \\
\hline Annual discharge, acre-feet & 10,430 & 9,850 & 10,350 & 11,220 & 11,150 \\
\hline $\begin{array}{l}\text { Variance of estimate of the annual discharge, } \\
(\text { acre-feet })^{2}\end{array}$ & 9,430 & 14,830 & 14,830 & 20,650 & 41,980 \\
\hline $\begin{array}{l}\text { Standard error of the annual discharge, acre- } \\
\text { feet }\end{array}$ & 97 & 122 & 122 & 144 & 205 \\
\hline $\begin{array}{l}\text { Standard error of the annual discharge, } \\
\text { percent }\end{array}$ & 0.93 & 1.24 & 1.17 & 1.28 & 1.84 \\
\hline
\end{tabular}




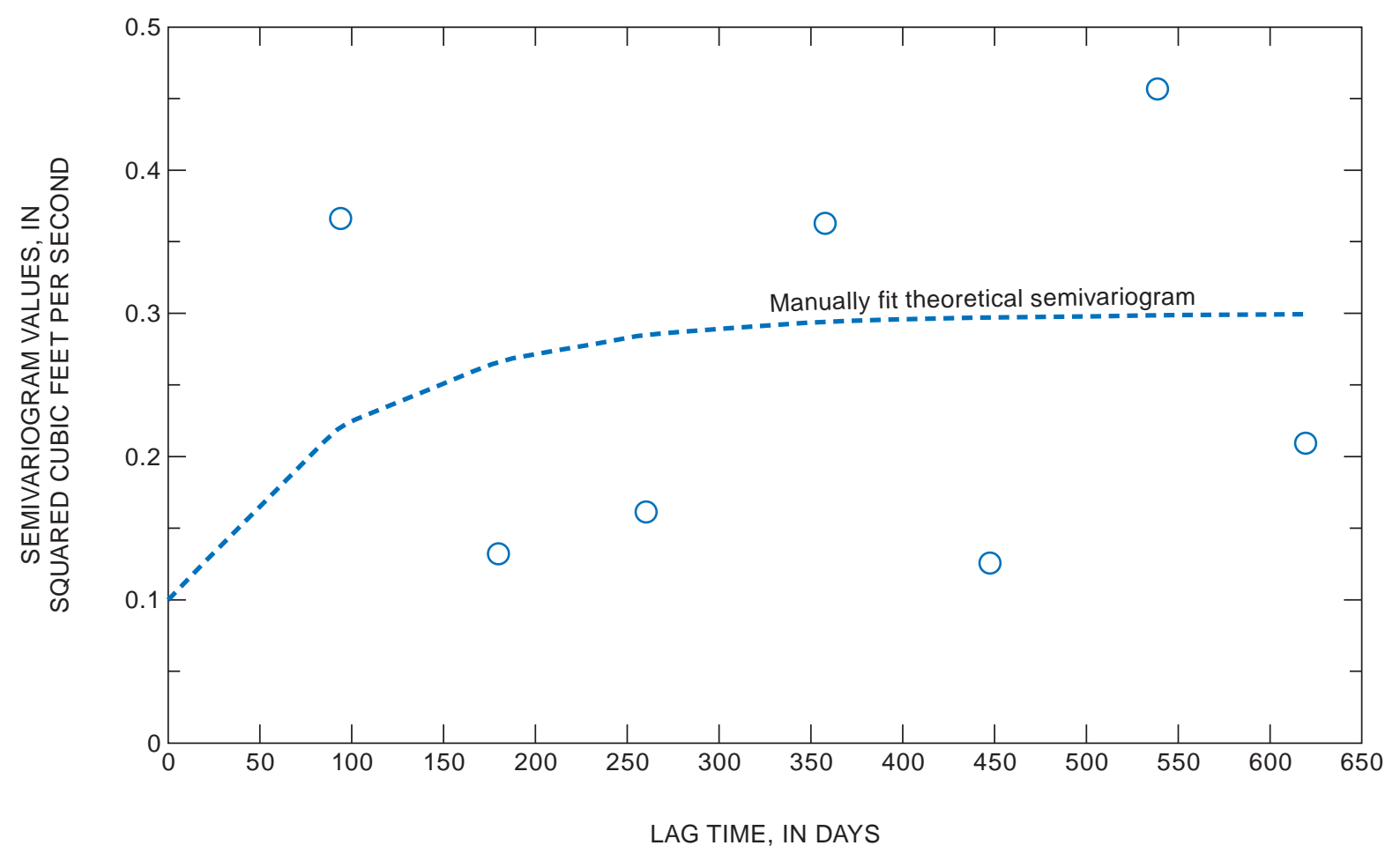

Figure 23. Semivariogram of discharge-rating residuals for Mittry Lake Diversion at Imperial Dam, January 1, 1995, to December 31, 1999. Blue circles represent the empirical semivariogram.

\section{Gila Gravity Main Canal at Imperial Dam}

Discharge in the Gila Gravity Main Canal at Imperial Dam is monitored at two streamflow-gaging stations. The USGS operates a streamflow-gaging station at which discharge is computed on the basis of a stage-discharge rating; this station is referred to in this report as the "stilling-well gage." The BOR operates the other streamflowgaging station at which discharge is computed by using an AVM and a stage-area rating; this station is referred to in this report as the "AVM gage." The AVM gage is a few hundred feet downstream from the Gila Sluiceway, and the stilling-well gage is about $0.25 \mathrm{mi}$ downstream from the AVM gage. Although the canal is earthen, gains or losses of discharge between the streamflow-gaging stations are assumed negligible.

Discharge at the stilling-well gage for 1995-99 was computed on the basis of a stage-discharge relation. Discharge was measured from a cableway near the stilling well by using vertical-axis current meters, and stage was monitored continuously by a float in the stilling well. On the basis of 148 stage and discharge measurements made from September 1993 through December 1999, a single time-dependent stage-discharge rating was developed (table 11). A theoretical semivariogram of the discharge-rating residuals was fit by nonlinear least squares (fig. 24). The effective percent error for discharge measurements, as determined from the semivariogram, was 2.59 percent. Application of the modified Moss and Gilroy method yielded estimates of the standard error of the annual discharge for 1995-99 that ranged from 0.88 to 0.96 percent (table 11). 
Table 11. Summary of error-analysis results for the annual discharge at Gila Gravity Main Canal at Imperial Dam (stilling-well gage) [ $q_{r}$, discharge; $h$, gage height; $t$, time in decimal years; $\mathrm{ft}^{3} / \mathrm{s}$, cubic feet per second]

\begin{tabular}{|c|c|c|c|c|c|}
\hline \multicolumn{6}{|c|}{ Summary of discharge-rating residuals } \\
\hline Discharge-rating period & $9 / 8 / 93$ to $12 / 31 / 9$ & & & & \\
\hline Discharge-rating equation & \multicolumn{5}{|c|}{$q_{r}=207.7(h-10.60-0.003(t-1995)-0.445 \cos (2 \pi t)-0.186 \sin (2 \pi t))^{1.02}$} \\
\hline Number of measurements & \multicolumn{5}{|c|}{148} \\
\hline Average discharge for measurements, $\mathrm{ft}^{3} / \mathrm{s}$ & \multicolumn{5}{|l|}{1,370} \\
\hline $\begin{array}{l}\text { Effective percent error for discharge } \\
\text { measurements }\end{array}$ & \multicolumn{5}{|l|}{2.59} \\
\hline Measurement variance, $\left(\mathrm{ft}^{3} / \mathrm{s}\right)^{2}$ & \multicolumn{5}{|l|}{1,370} \\
\hline Process variance, $\left(\mathrm{ft}^{3} / \mathrm{s}\right)^{2}$ & \multicolumn{5}{|l|}{9,270} \\
\hline $\begin{array}{l}\text { One-day residual serial-correlation coefficient } \\
\text { for discharge-rating residuals }\end{array}$ & \multicolumn{5}{|l|}{0.953} \\
\hline \multicolumn{6}{|c|}{ Uncertainty in the annual discharge } \\
\hline & 1995 & 1996 & 1997 & 1998 & 1999 \\
\hline Number of discharge measurements & 22 & 23 & 25 & 23 & 24 \\
\hline Annual discharge, acre-feet & 765,200 & 802,900 & 774,600 & 763,800 & 765,200 \\
\hline $\begin{array}{l}\text { Variance of estimate of the annual discharge, } \\
\quad(\text { acre-feet })^{2}\end{array}$ & $54,770,000$ & $51,680,000$ & $46,330,000$ & $51,680,000$ & $48,900,000$ \\
\hline $\begin{array}{l}\text { Standard error of the annual discharge, } \\
\text { acre-feet }\end{array}$ & 7,380 & 7,190 & 6,810 & 7,190 & 6,990 \\
\hline $\begin{array}{l}\text { Standard error of the annual discharge, } \\
\text { percent }\end{array}$ & 0.96 & 0.90 & 0.88 & 0.94 & 0.91 \\
\hline
\end{tabular}

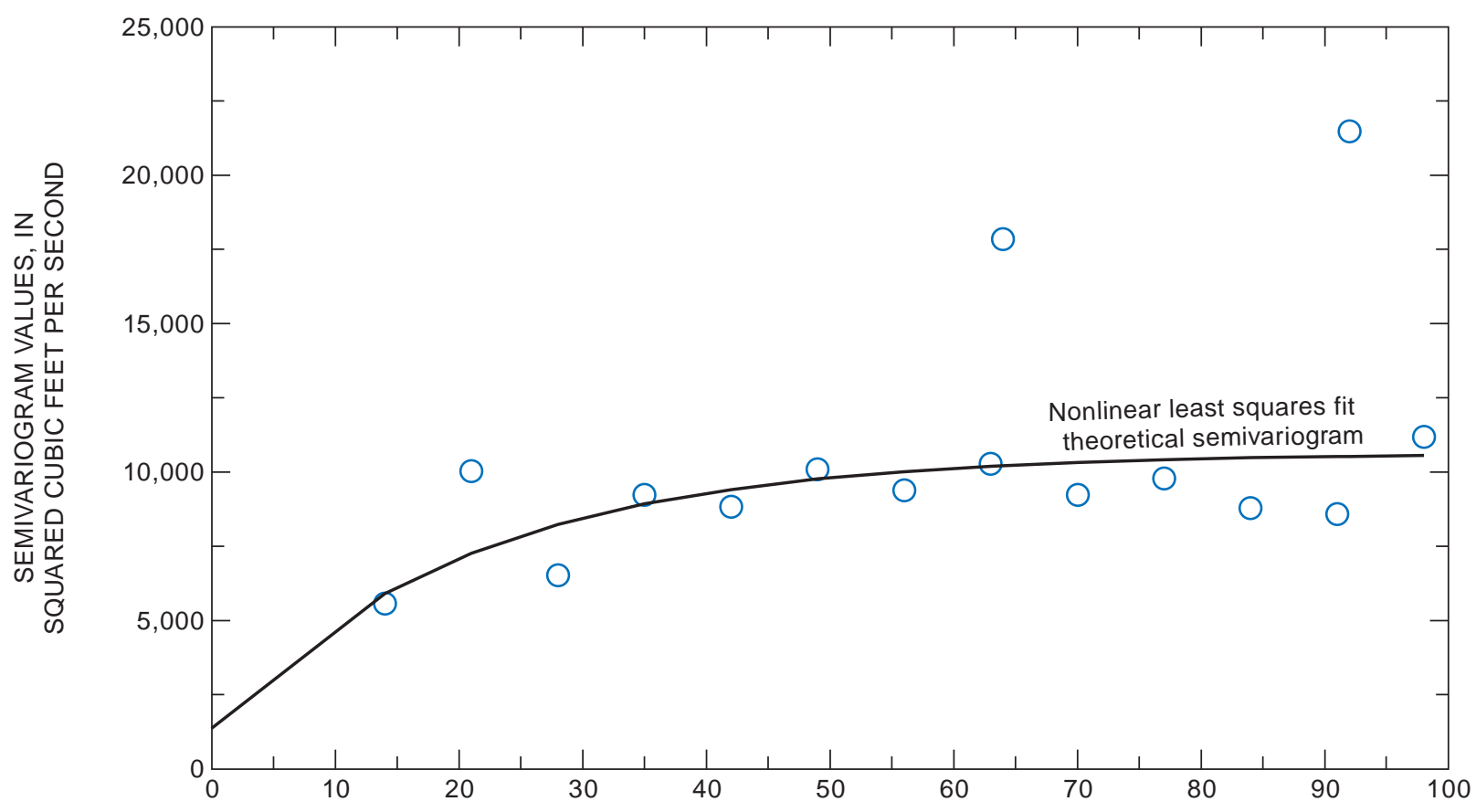

LAG TIME, IN DAYS

Figure 24. Semivariogram of discharge-rating residuals for the stilling-well gage on the Gila Gravity Main Canal at Imperial Dam, September 8, 1993, to December 31, 1999. Blue circles represent the empirical semivariogram. 
Discharge at the AVM gage for 1996-99 was computed on the basis of velocity measured by an AVM and a stage-area rating. The AVM measured an index velocity along a single path and also measured stage acoustically. Monthly broadband ADCP measurements were used to verify the discharge rating since 1996. These measurements were only used to verify the validity of the discharge rating; however, shifts were not applied to the discharge rating to account for any discrepancies between the measured discharge and the computed discharge at the time of the measurements. Each broadband ADCP measurement consists of 10 transects; the assigned discharge for the measurement was the truncated mean discharge of the transects (excludes the transects with the largest and smallest discharge). Truncated sample standard deviations (excludes the transects with the largest and smallest discharge) were provided with the discharge measurement data and were divided by the measured discharge as an estimate of the percent error, $\alpha_{i}$, for the individual discharge measurement. On the basis of 51 measurements of discharge, stage and AVM index velocity measurements made during 1996-99, a single rating was developed (table 12). A theoretical semivariogram was fit manually for the empirical semivariogram of the discharge-rating residuals (fig. 25). Measurement variance could not be clearly determined from the semivariogram; therefore, the average squared-truncated sample standard deviation was used as an estimate of the measurement variance. Application of the modified Moss and Gilroy method yielded estimates of the standard error of the annual discharge for 1996-99 that ranged from 0.46 to 0.49 percent. Note that because the discharge rating was not shifted at this station, the number of measurements made per year effectively is zero for the purpose of determining the error in the annual discharge.

Table 12. Summary of error-analysis results for the annual discharge at Gila Gravity Main Canal at Imperial Dam (acoustic velocity meter gage)

[ $q_{r}$, discharge; $h$, gage height; $v_{i}$, acoustic velocity meter index velocity; $\mathrm{ft}^{3} / \mathrm{s}$, cubic feet per second]

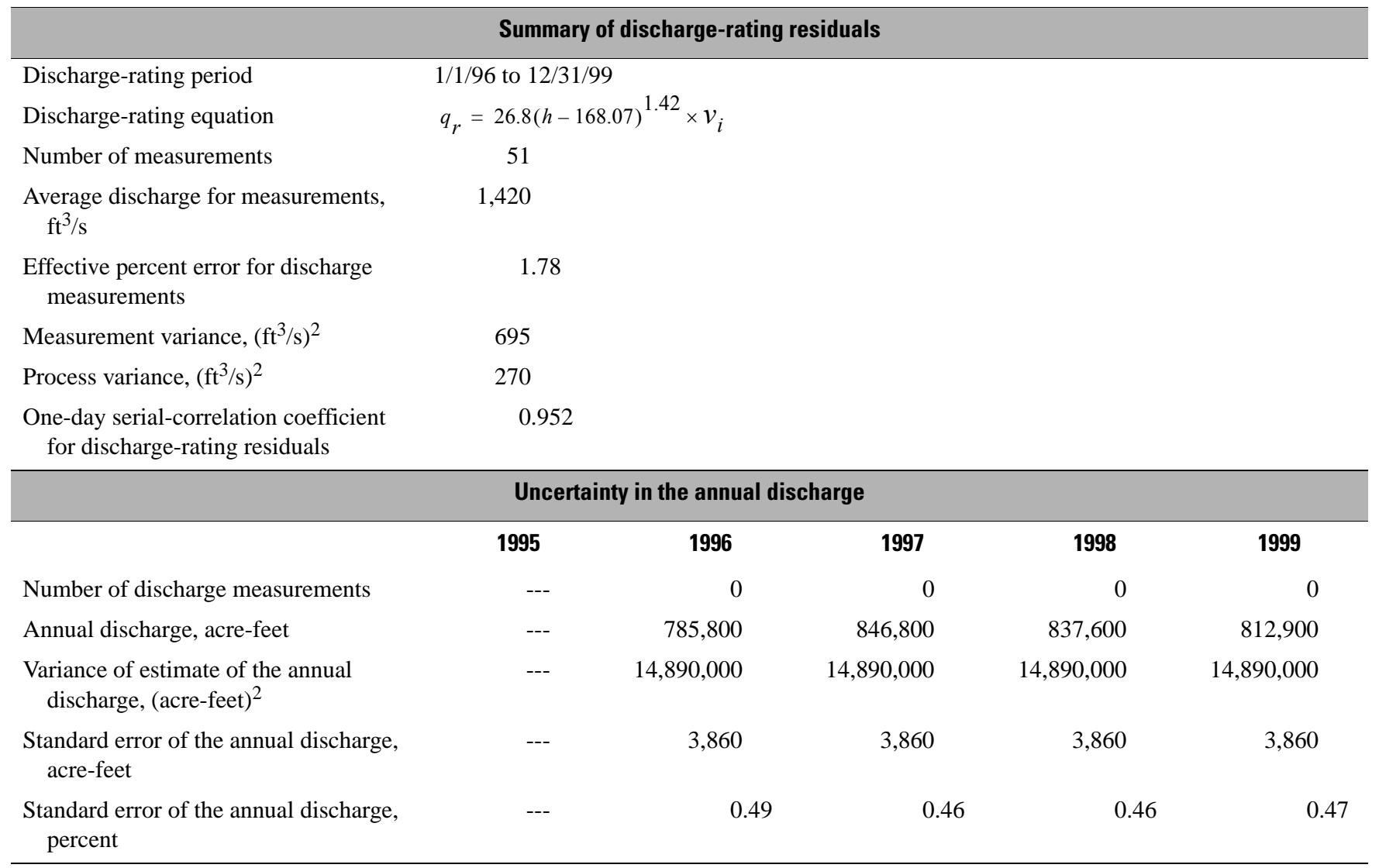




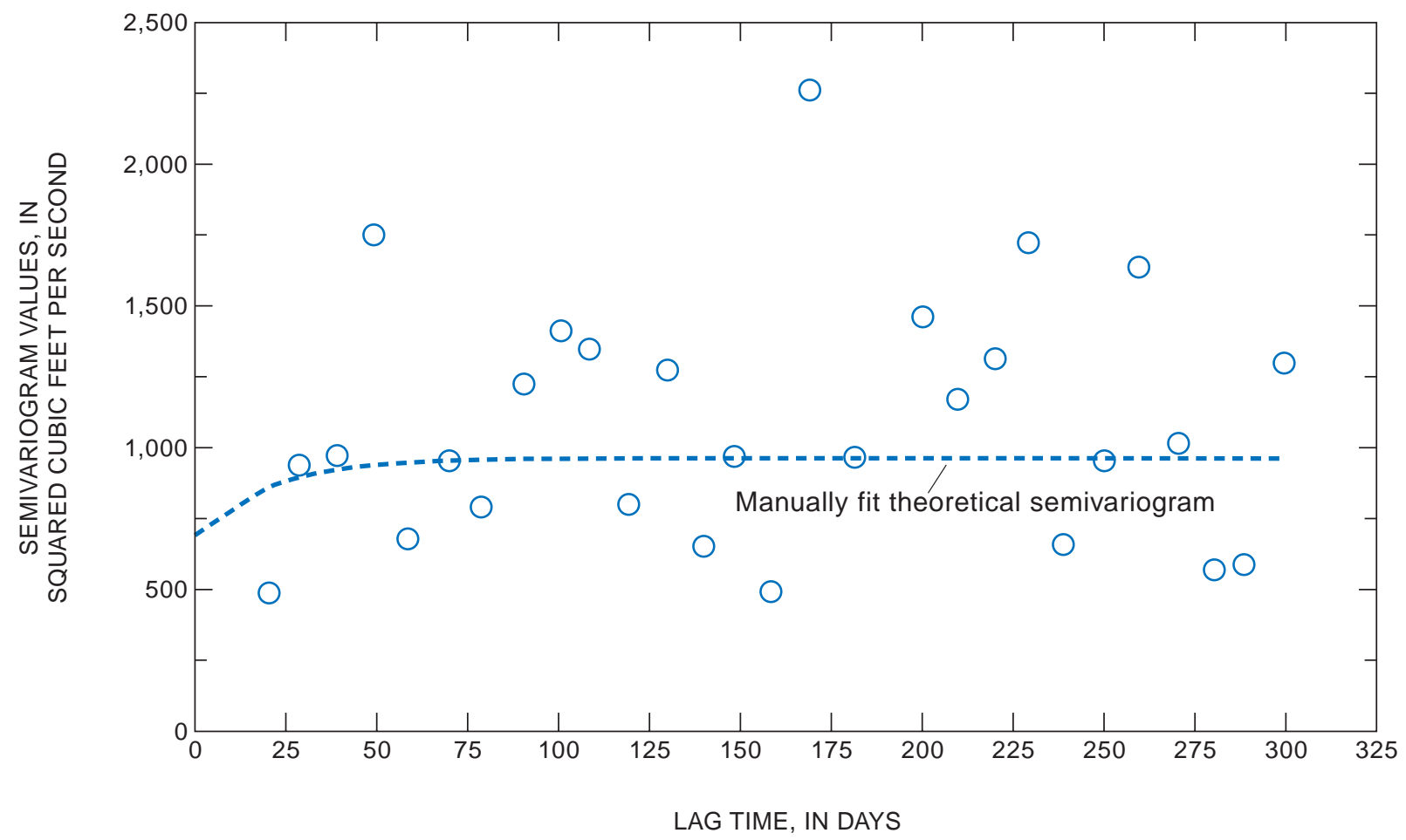

Figure 25. Semivariogram of discharge-rating residuals for the acoustic-velocity meter gage on the Gila Gravity Main canal at Imperial Dam, January 1, 1996, to December 31, 1999. Blue circles represent the empirical semivariogram.

\section{Wellton-Mohawk Canal}

Discharge in the Wellton-Mohawk Canal is monitored at two streamflow-gaging stations. The USGS operates a streamflow-gaging station at which discharge is computed on the basis of a rating for a control structure that consists of two radial gates; this station is referred to in this report as the "radial-gates gage." The control structure regulates the flow of water from the Gila Gravity Main Canal into the Wellton-Mohawk Canal. The BOR operates the other streamflow-gaging station at which discharge is computed by using an AVM and a stage-area rating; this station is referred to in this report as the "AVM gage." The AVM gage is a few hundred feet downstream from the radial-gates gage on the trapezoidal, concrete-lined canal. Gains or losses of discharge between the streamflowgaging stations are assumed negligible.

Discharge at the radial-gates gage for 1995-99 was computed on the basis of forebay stage, afterbay stage, and the gate opening. The radial gates generally were operated in tandem. Discharge was measured from a foot bridge about $650 \mathrm{ft}$ downstream from the control structure by using a vertical axis current meter. Forebay stage and afterbay stage were monitored continuously with float-tape gages in stilling wells upstream and downstream, respectively, from the control structure. Calibrated scales on the control structure serve as gate-opening reference gages, and a continuous record of gate openings was transmitted to a control room at the control structure. On the basis of 120 forebay stage, afterbay stage, gate opening, and discharge measurements made during 1979-99, a single discharge rating was developed (table 13). A theoretical semivariogram of the discharge-rating residuals was fit by nonlinear least squares (fig. 26). The measurement variance determined from the semivariogram was larger than that determined on the basis of equation 8 and $\alpha_{i}$, which was determined by using the Sauer and Meyer method. This was reasonable because $\alpha_{i}$, determined on the basis of the Sauer and Meyer method, does not account for the uncertainty in gate opening or stage readings, which for this station, cannot be neglected. The gate-opening indicators are marked only to the nearest $0.1 \mathrm{ft}$, and the pointers are somewhat far from the scale, which results in an estimated gate opening error of about $0.05 \mathrm{ft}$. The measurement variance resulting from the error of gate- 
opening readings, as estimated by propagating it through the discharge rating ${ }^{1}$ (listed in table 13), was 94.4 squared $\mathrm{ft}^{3} / \mathrm{s}$, which is about one quarter of the total measurement variance. Application of the modified Moss and Gilroy method yielded estimates of the standard error of the annual discharge for 1995-99 that ranged from 1.19 to 1.61 percent (table 13).

Table 13. Summary of error-analysis results for the annual discharge at Wellton-Mohawk Canal (radial-gates gage)

[ $q_{r}$, discharge; $h_{1}$, forebay gage height; $h_{2}$, afterbay gage height; $h_{\mathrm{g}}$, gate opening; $\mathrm{ft}^{3} / \mathrm{s}$, cubic feet per second]

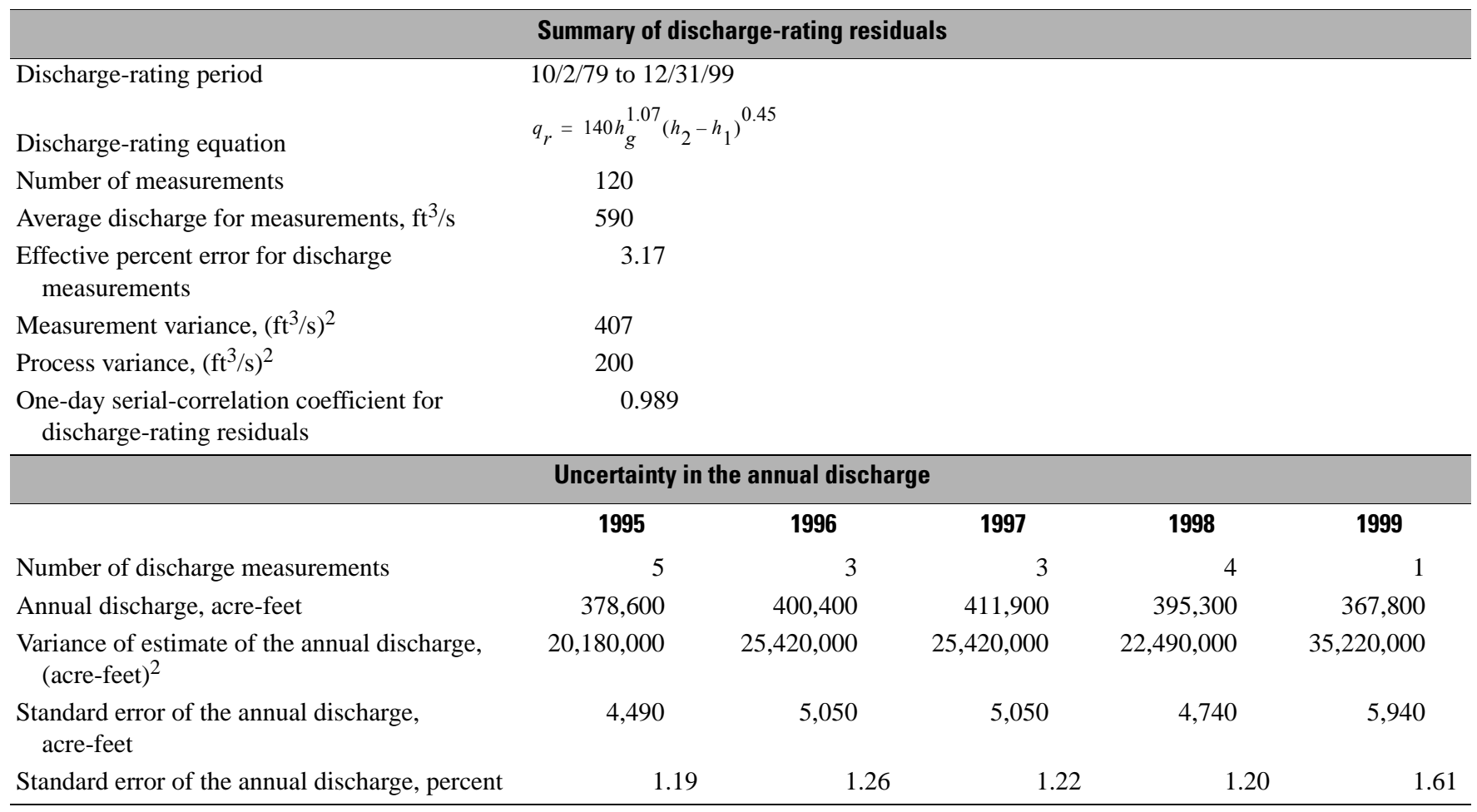

\footnotetext{
${ }^{1}$ The measurement variance, in units of discharge, resulting from the variance of estimate of gate-opening readings, in units of length, can be estimated by propagating the variance of estimate of the gate-opening readings through the discharge rating:

$$
S_{m}^{2}\left(h_{g}\right)=\left.\left(\frac{\partial q_{r}}{\partial h_{g}}\right)^{2}\right|_{\overline{h_{g}}, \overline{h_{2}-h_{1}}} \times S_{h_{g}^{2}},
$$

where

$$
\begin{aligned}
& s_{m}^{2}\left(h_{g}\right) \\
& S_{h_{g}}^{2} \quad=\quad \text { variance of estimate for the gate opening readings, in units of length, and } \\
& \left.\left(\frac{\partial q_{r}}{\partial h_{g}}\right)^{2}\right|_{\overline{h_{g}}, \overline{h_{2}-h_{1}}}=\quad \frac{\text { square of the part }}{\overline{h_{2}-h_{1}} ; \text { where }} \\
& \overline{\mathrm{h}}_{\mathrm{g}} \quad=\quad \text { mean gate opening for the readings associated with the discharge measurements, and } \\
& \overline{h_{2}-h_{1}} \quad=\quad \begin{array}{l}
\text { mean head (the difference between the forebay and afterbay gage-height readings) associated with the dis- } \\
\text { charge measurements. }
\end{array}
\end{aligned}
$$




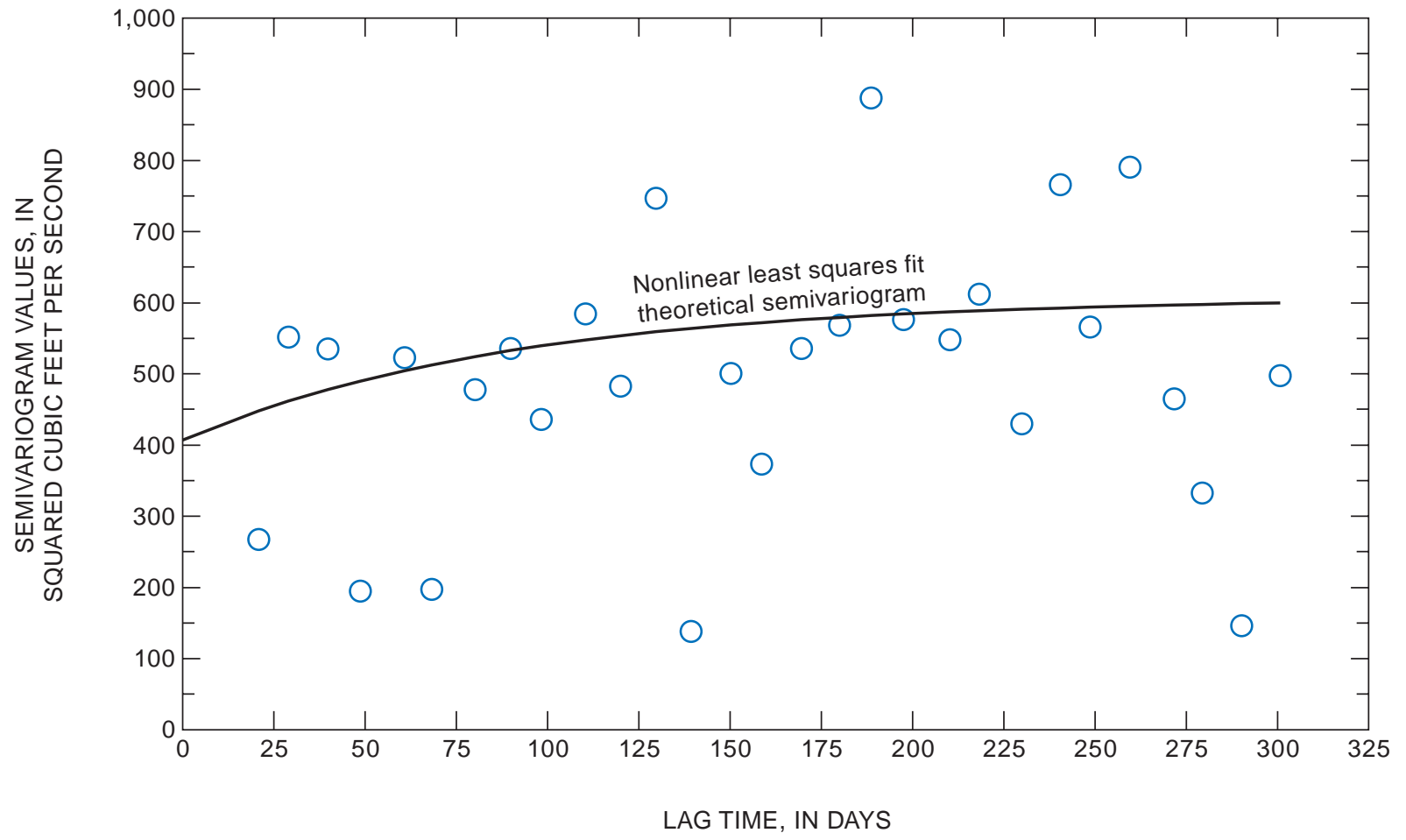

Figure 26. Semivariogram of discharge-rating residuals for the radial-gates gage on the Wellton-Mohawk Canal, December 2, 1979, to December 31, 1999. Blue circles represent the empirical semivariogram.

Discharge at the AVM gage for 1996-99 was computed on the basis of velocity measured by an AVM and a stage-area relation. The AVM measured an index velocity along a single path and also measured stage acoustically. Monthly broadband ADCP measurements have been used to verify the discharge rating since 1996 . These measurements were only used to verify the validity of the discharge rating; however, shifts were not applied to the discharge rating to account for any discrepancies between the measured discharge and the computed discharge at the time of the measurements. Each broadband ADCP measurement consists of 10 transects; the assigned discharge for the measurement was the truncated mean discharge of the transects. Truncated sample standard deviations were provided with the discharge data and were divided by the measured discharge as an estimate of the percent error, $\alpha_{i}$, for the individual discharge measurement. On the basis of 49 measurements of discharge, stage, and AVM index velocity made during 1996-99, a single non-time-dependent rating was developed (table 14). A theoretical semivariogram of the discharge-rating residuals was fit by nonlinear least squares (fig. 27). Measurement variance determined from the semivariogram was comparable but slightly larger than that determined on the basis of truncated sample standard deviations for individual discharge measurements. This difference is expected because removing the large and small discharges from the sample standard deviation estimate has the effect of decreasing the estimate of the measurement variance. Application of the modified Moss and Gilroy method yielded estimates of error of the annual discharge for 1996-99 that ranged from 1.29 to 1.34 percent (table 14). Note that because the discharge rating was not shifted at this station, the number of measurements made per year effectively is zero for the purpose of determining the error in the annual discharge. 
Table 14. Summary of error-analysis results for the annual discharge at Wellton-Mohawk Canal (acoustic velocity meter gage) $\left[q_{r}\right.$, discharge; $h$, gage height; $v_{i}$, acoustic velocity meter index velocity, $t$; time, in decimal years; $\mathrm{ft}^{3} / \mathrm{s}$, cubic feet per second]

\begin{tabular}{|c|c|c|c|c|}
\hline \multicolumn{5}{|c|}{ Summary of discharge-rating residuals } \\
\hline Rating period & $1 / 1 / 96$ to $12 / 31 / 1999$ & & & \\
\hline Discharge-rating equation & \multicolumn{2}{|c|}{$q_{r}=185(h-164.32+0.085(t-1995))^{0.49} \times v_{i}$} & & \\
\hline Number of measurements & \multicolumn{2}{|c|}{49} & & \\
\hline $\begin{array}{l}\text { Average discharge for measurements, } \\
\mathrm{ft}^{3} / \mathrm{s}\end{array}$ & \multicolumn{2}{|l|}{597} & & \\
\hline $\begin{array}{l}\text { Effective percent error for discharge } \\
\text { measurements }\end{array}$ & 1.70 & & & \\
\hline Measurement variance, $\left(\mathrm{ft}^{3} / \mathrm{s}\right)^{2}$ & 118 & & & \\
\hline Process variance, $\left(\mathrm{ft}^{3} / \mathrm{s}\right)^{2}$ & 95 & & & \\
\hline $\begin{array}{l}\text { One-day serial-correlation coefficient for } \\
\text { discharge-rating residuals }\end{array}$ & \multicolumn{2}{|l|}{0.993} & & \\
\hline \multicolumn{5}{|c|}{ Uncertainty in the annual discharge $^{1}$} \\
\hline & 1995 & 1997 & 1998 & 1999 \\
\hline Number of discharge measurements & --- & 0 & 0 & 0 \\
\hline Annual discharge, acre-feet & 385,200 & 371,500 & 382,900 & 372,600 \\
\hline $\begin{array}{l}\text { Variance of estimate of the annual } \\
\text { discharge, }(\text { acre-feet })^{2}\end{array}$ & $24,860,000$ & $24,860,000$ & $24,860,000$ & $24,860,000$ \\
\hline $\begin{array}{l}\text { Standard error of the annual discharge, } \\
\text { acre-feet }\end{array}$ & 4,990 & 4,990 & 4,990 & 4,990 \\
\hline $\begin{array}{l}\text { Standard error of the annual discharge, } \\
\text { percent }\end{array}$ & 1.29 & 1.34 & 1.30 & 1.34 \\
\hline
\end{tabular}

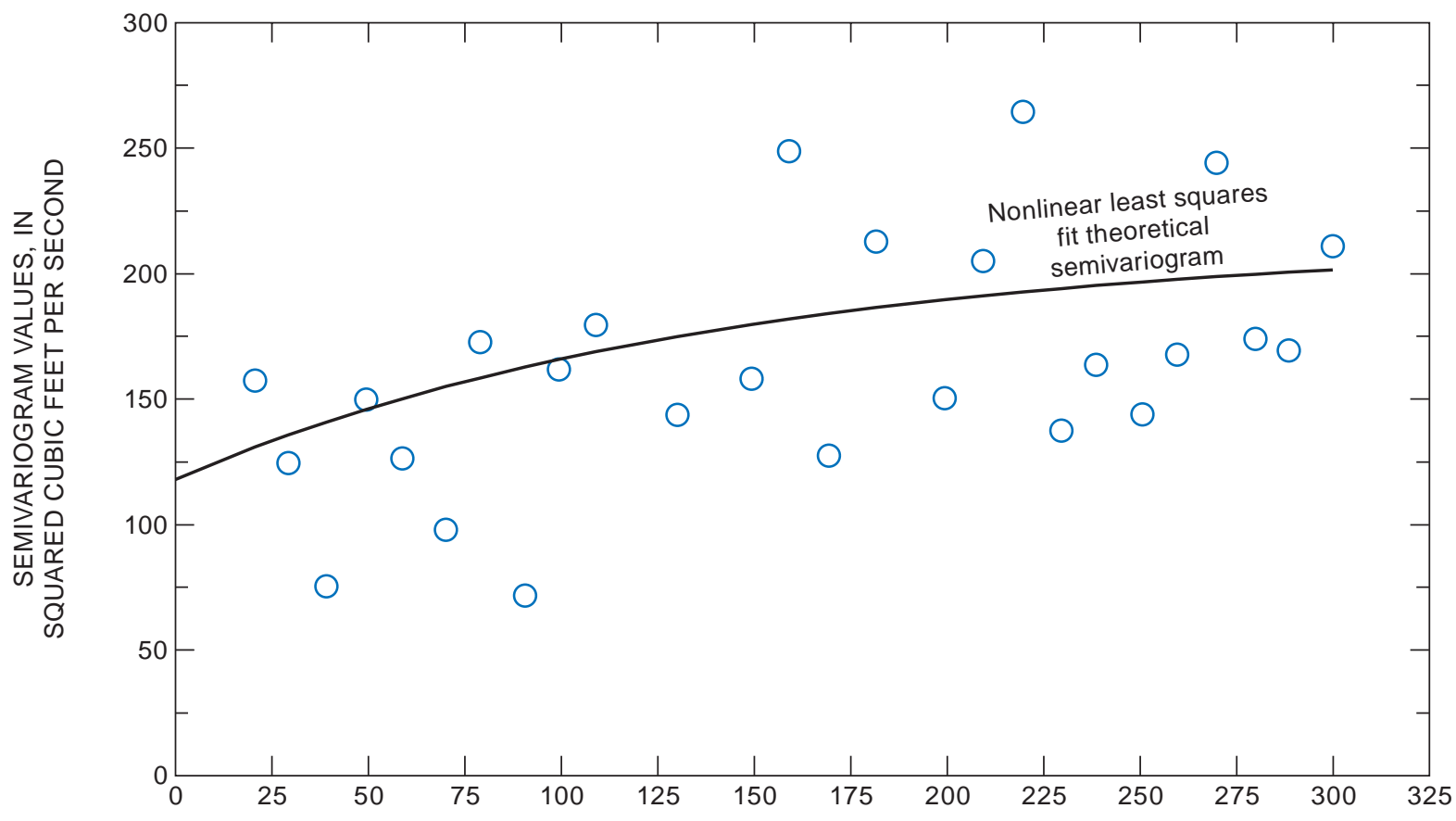

LAG TIME, IN DAYS

Figure 27. Semivariogram of discharge-rating residuals for the acoustic-velocity meter gage on the Wellton-Mohawk Canal, January 1, 1996, to December 31, 1999. Blue circles represent the empirical semivariogram. 
A bias was detected in the discharge rating for the AVM gage. Linear regression detected a $+6.89 \mathrm{ft}^{3} / \mathrm{s}$ per year $(+4,990 \mathrm{acre}-\mathrm{ft} / \mathrm{yr}$ per year) trend in the residuals from the discharge rating that was developed as part of this study. Therefore, after 4 years, the annual discharge with this rating would be underestimated by nearly 20,000 acre-ft/yr. It is likely that this bias is also present in the discharge computed for the AVM gage because the discharge rating does not contain a temporal component, nor is the discharge rating shifted.

\section{All-American Canal near Imperial Dam}

The All-American Canal near Imperial Dam streamflow-gaging station (site 16, figs. 1 and 2) is about $1 \mathrm{mi}$ downstream from Imperial Dam and is operated cooperatively by the Imperial Irrigation District (IID) and the USGS. Discharge for 1995-99 was computed on the basis of a stage-discharge relation. Discharge was measured from a cableway at a trapezoidal concrete section of the canal near the gage house by using vertical-axis current meters, and stage was monitored continuously with a float-tape gage in a stilling well. Stage and discharge measurements were made about once a month by USGS personnel and about twice a week by IID personnel. Discharge measurements from both agencies were used by IID to compute discharge, and daily discharge data were published annually in USGS data reports for Arizona (such as Tadayon and others, 2000) under station number 09523000. On the basis of 555 stage and discharge measurements made during 1995-2000, an unbiased timedependent stage-discharge rating was developed (table 15). A theoretical semivariogram of the discharge-rating residuals was fit by nonlinear least squares (fig. 28). Measurement variance was determined from the theoretical semivariogram. The $\alpha_{e}$ (1.45 percent) obtained by using the measurement variance determined from the theoretical semivariogram was less than the $\alpha_{e}$ (2.4 percent) determined ${ }^{2}$ on the basis of the measurement variance estimated from equation 8 and values of $\alpha_{i}$ determined by using the Sauer and Meyer method. Application of the modified Moss and Gilroy method yielded estimates of the standard error of the annual discharge for 1995-99 that ranged from 0.11 to 0.17 percent (table 15). In practice, the IID computes a discharge-rating shift for time $t$ only on the basis of discharge measurements made up to time $t$ (real-time computation of discharge). This method produces a discharge estimate that has more uncertainty than a discharge estimate would have that is based on a dischargerating shift that uses information from the measurements before and after time $t$ (see Moss and Gilroy, 1980, pages 25-29). Therefore, the standard error of the annual discharge for this station provided herein most likely underestimates the true error.

\footnotetext{
${ }^{2}$ For discharge measurements collected by the IID, ancillary discharge-measurement data, such as the number of vertical sections, mean depth, and mean velocity that are used in the Sauer and Meyer (1992) method were not available in a concise, electronic format. Therefore, the estimate for $\alpha_{e}$ was determined on the basis of 141 discharge measurements made by USGS personnel from 1985 through 1999. The uncertainty in discharge measurements made by IID personnel should be similar to the uncertainty in those made by USGS personnel because the agencies use similar techniques and the same measuring section.
} 
Table 15. Summary of error-analysis results for the annual discharge at All-American Canal near Imperial Dam [ $q_{r}$, discharge; $h$, gage height; $t$, time in decimal years; $\mathrm{ft}^{3} / \mathrm{s}$, cubic feet per second]

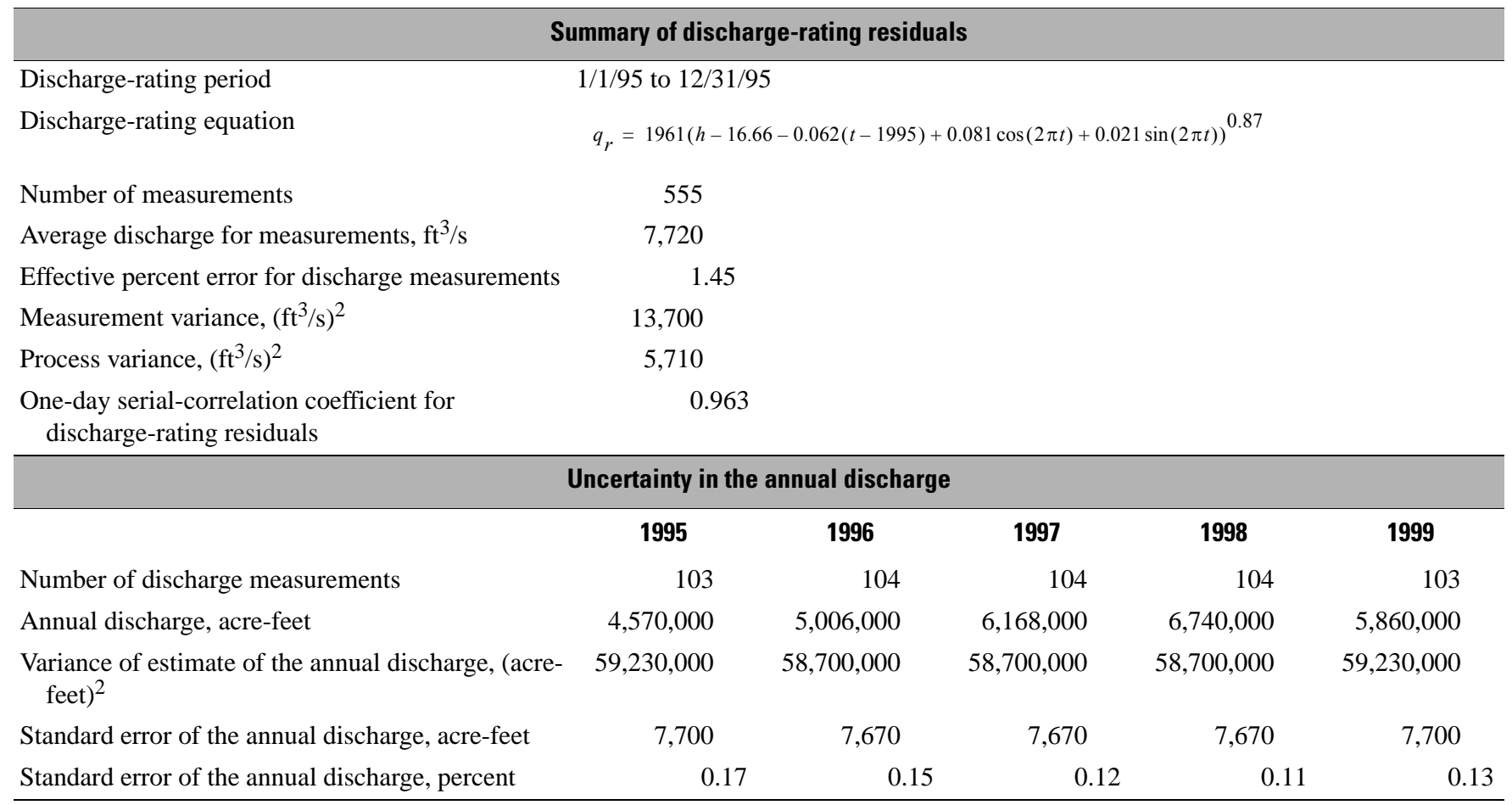

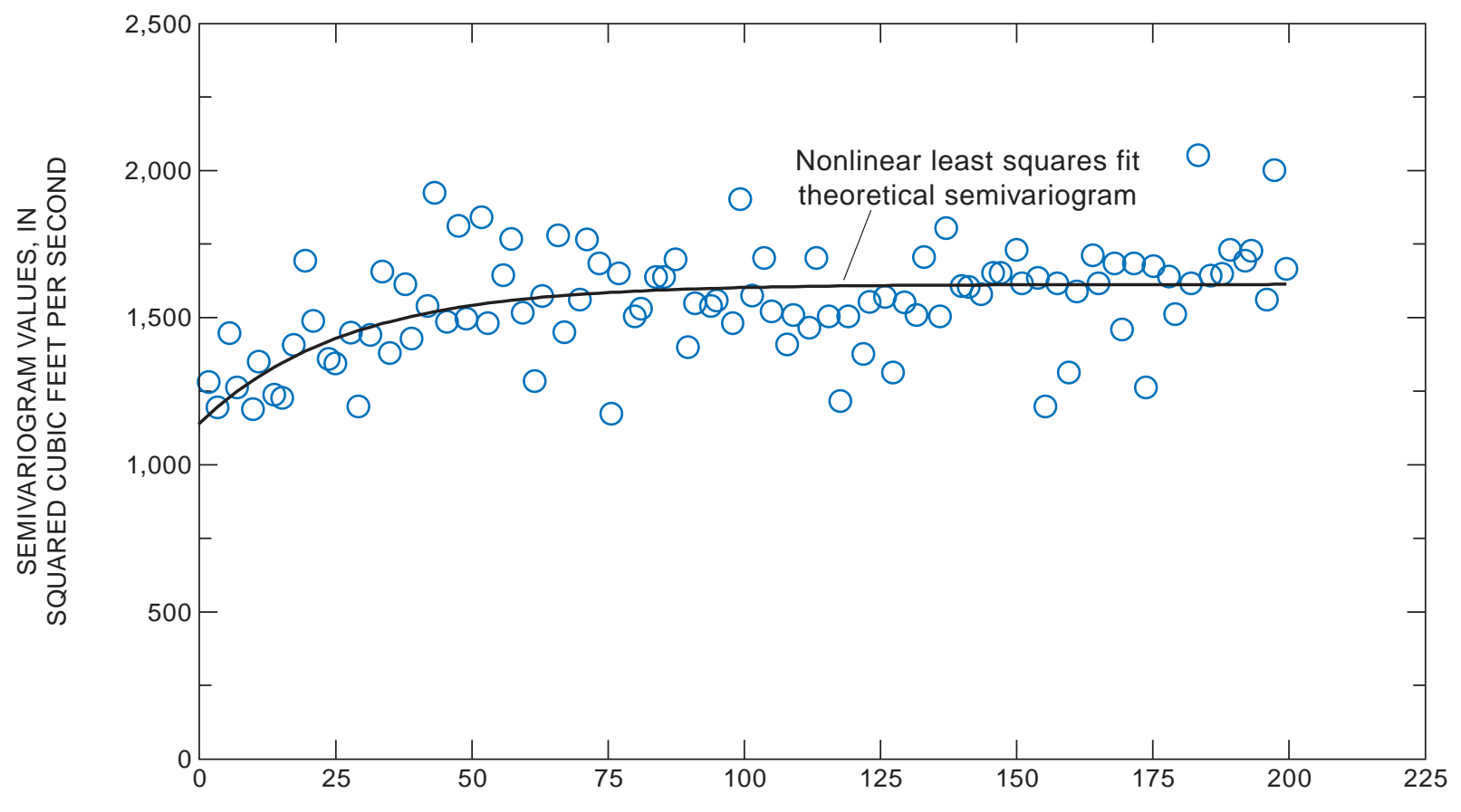

LAG TIME, IN DAYS

Figure 28. Semivariogram of discharge-rating residuals for All-American Canal near Imperial Dam, January 1, 1995, to December 31, 1999. Blue circles represent the empirical semivariogram. 


\section{All-American Canal below Pilot Knob wasteway}

The IID operates the All-American Canal below Pilot Knob wasteway streamflow-gaging station (site 17, figs. 1 and 2), which is about $0.5 \mathrm{mi}$ downstream from Pilot Knob wasteway and about 21 mi downstream from the intake at Imperial Dam. The control for the station was the Pilot Knob check structure, which consists of seven radial gates that are usually operated in tandem. Discharge for 1995-99 was computed on the basis of forebay stage, afterbay stage, and gate opening. Discharge was measured from a cableway about $0.5 \mathrm{mi}$ downstream from the check gates by using vertical-axis current meters. Forebay stage and afterbay stage were monitored continuously with float-tape gages in stilling wells upstream and downstream, respectively, from the Pilot Knob check structure. Gate openings were indicated on the check structure by a scale attached to the vertical-wing wall. Gate openings were transmitted to the Pilot Knob Power Plant control room and logged, which formed a continuous record. Individual stage, gate opening, and discharge measurements were made about twice a year by USGS personnel, and once a week by IID personnel. Discharge measurements from both agencies were used by IID to compute discharge, and daily-discharge data were published annually in USGS data reports for Arizona (such as Tadayon and others, 2000) under station number 09527500.

Discharge ratings were developed for three periods from 1995 to 2000 on the basis of 278 stage and discharge measurements made by the USGS and IID (table 16). The discharge rating covering the first period contained a time-dependent correction to the gate opening, whereas the discharge ratings that cover the middle period and last period did not. The discharge rating covering the last period was developed because the gate-opening recording system was upgraded and the methodology of recording the gate openings changed. For the first and third period, theoretical semivariograms of the discharge-rating residuals were fit by nonlinear least squares (fig. 29). Measurement variance for these periods was determined from the theoretical semivariogram. The $\alpha_{e}$ for these periods ( 1.35 percent and 1.21 percent, respectively) obtained by using the measurement variance determined from the theoretical semivariograms was less than the $\alpha_{e}\left(2.6\right.$ percent) determined ${ }^{3}$ on the basis of the measurement variance estimated by using equation 8 and values of $\alpha_{i}$ determined with the Sauer and Meyer method. For the second period, a theoretical semivariogram of the discharge-rating residuals was fit manually (fig. 29).

Measurement variance could not be determined clearly from the empirical semivariogram for this period, so it was determined on the basis of equation 13 and $\alpha_{e}$ for the first period (1.35 percent). Application of the modified Moss and Gilroy method yielded estimates of the standard error of the annual discharge for 1995-99 that ranged from 0.16 to 0.19 percent (table 16). For years with two discharge-rating periods (1996 and 1998), the variances of the annual discharge were determined by using equation 15 to combine the variance of the discharge that accumulated during each discharge-rating period. In practice, a discharge-rating shift for time $t$ is determined only on the basis of discharge measurements made up to time $t$ (real-time computation of discharge). This method produces a discharge estimate that has more uncertainty than a discharge estimate would have that is based on a discharge-rating shift that uses information from the measurements before and after time $t$ (see Moss and Gilroy, 1980, pages 25-29). Therefore, the estimates of the error of the annual discharge for this station provided herein most likely underestimate the true error.

\footnotetext{
${ }^{3}$ For discharge measurements collected by the IID, ancillary discharge-measurement data, such as the number of vertical sections, mean depth, and mean velocity that are used in the Sauer and Meyer (1992) method were not available in a concise, electronic format. Therefore, the estimate for $\alpha_{e}$ was determined on the basis of 35 discharge measurements made by USGS personnel from 1985 through 1999. The uncertainty in discharge measurements made by IID personnel should be similar to the uncertainty in those measurements made by USGS personnel because the agencies use similar techniques and the same measuring section.
} 
Table 16. Summary of error-analysis results for the annual discharge at All-American Canal below Pilot Knob wasteway [ $q_{r}$, discharge; $h_{1}$, forebay gage height; $h_{2}$, afterbay gage height; $h_{\mathrm{g}}$, gate opening; $t$, time in decimal years; $\mathrm{ft}^{3} / \mathrm{s}$, cubic feet per second]

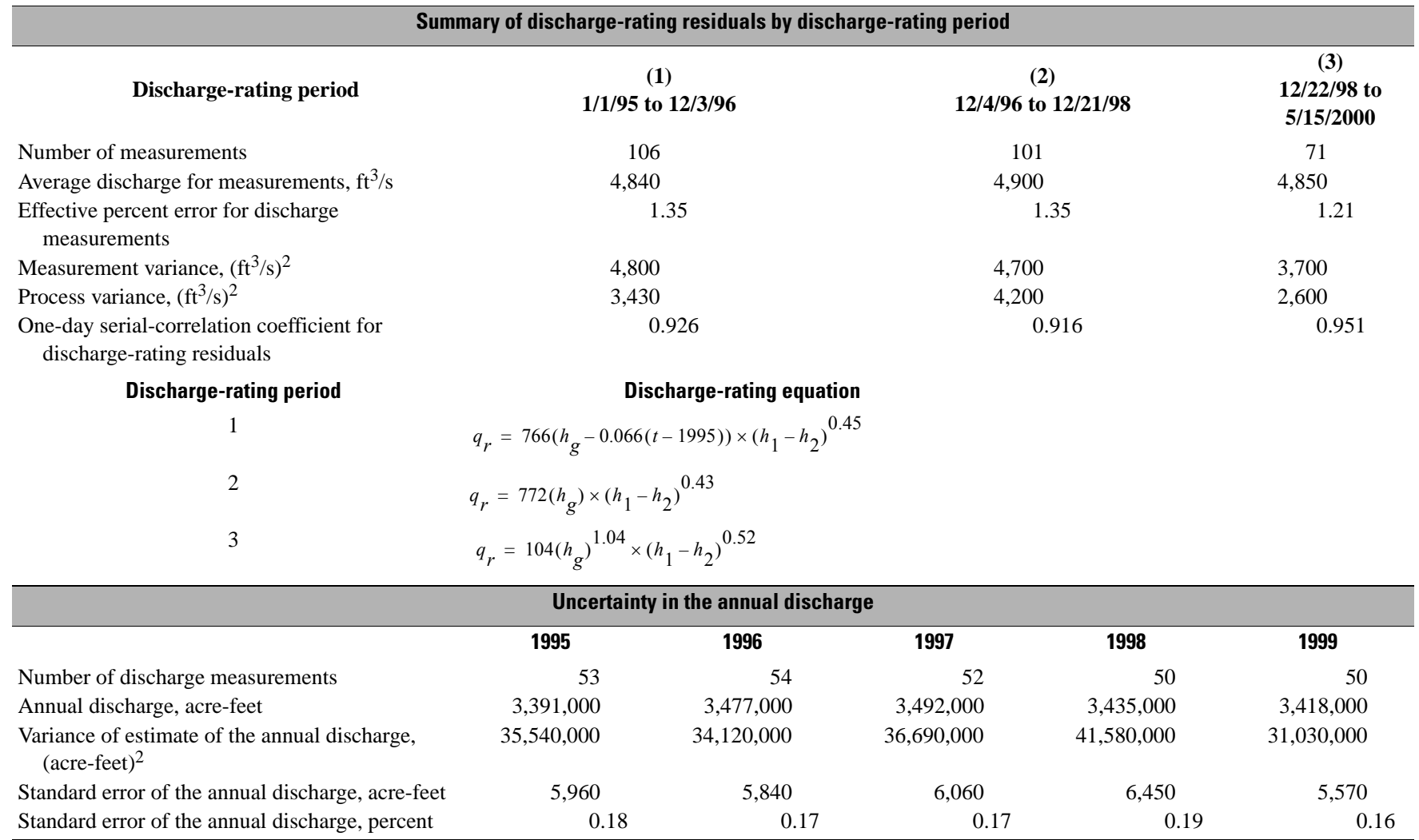

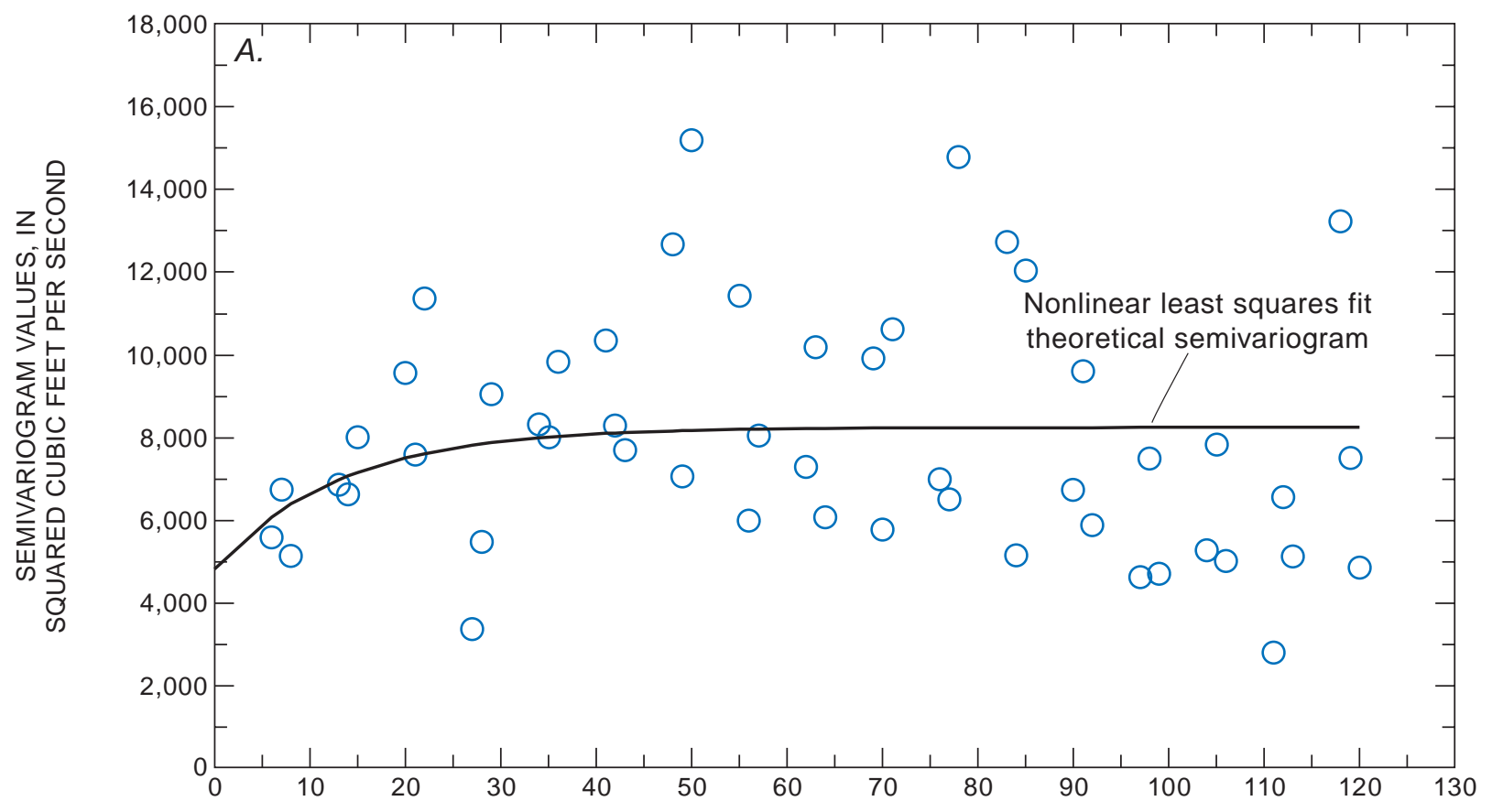

LAG TIME, IN DAYS

Figure 29. Semivariograms of discharge-rating residuals for All-American Canal below Pilot Knob Wasteway. A, January 1 , 1995, to December 3, 1996. B, December 4, 1996, to December 21, 1998. C, December 22, 1998, to May 15, 2000. Blue circles represent the empirical semivariogram. 


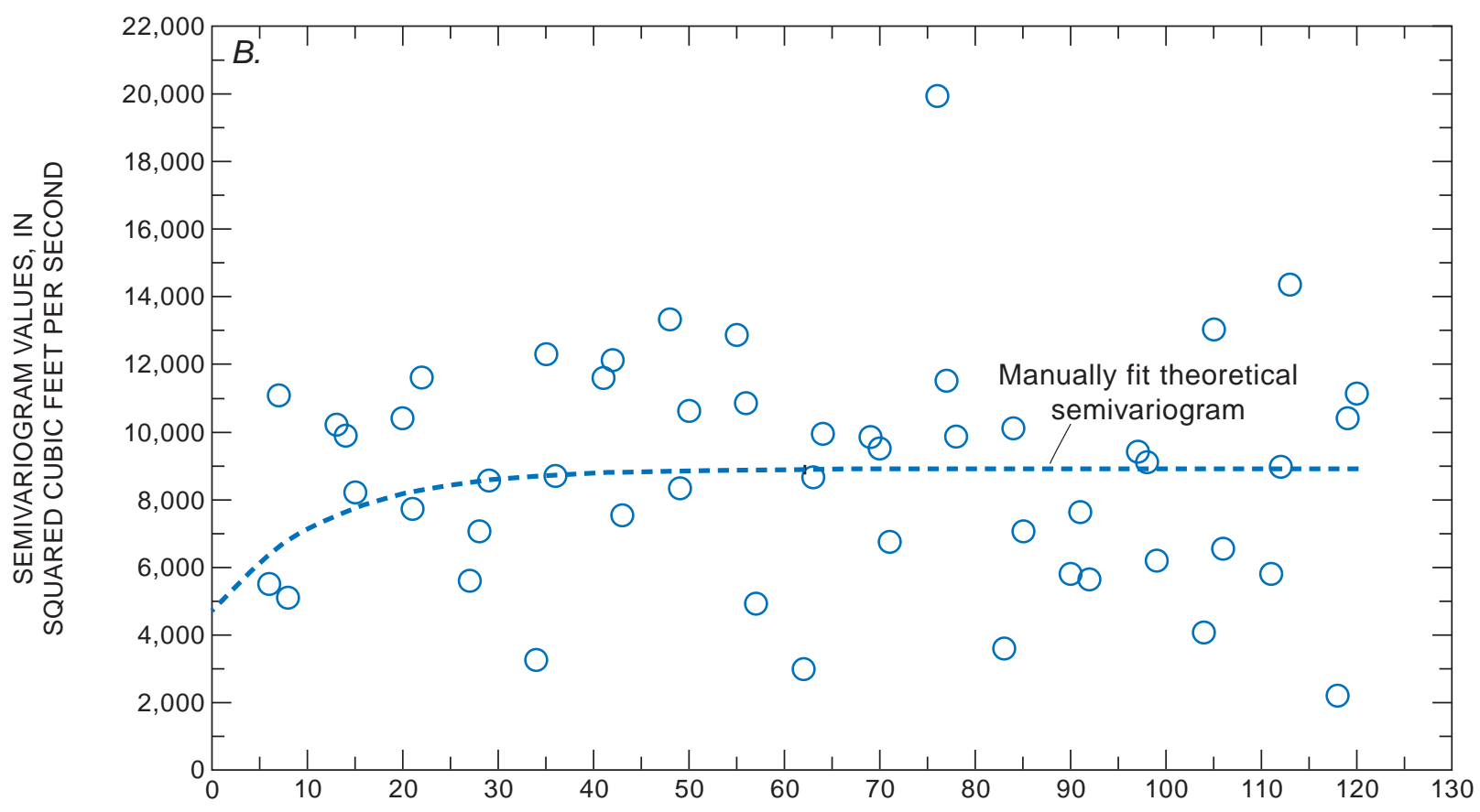

LAG TIME, IN DAYS

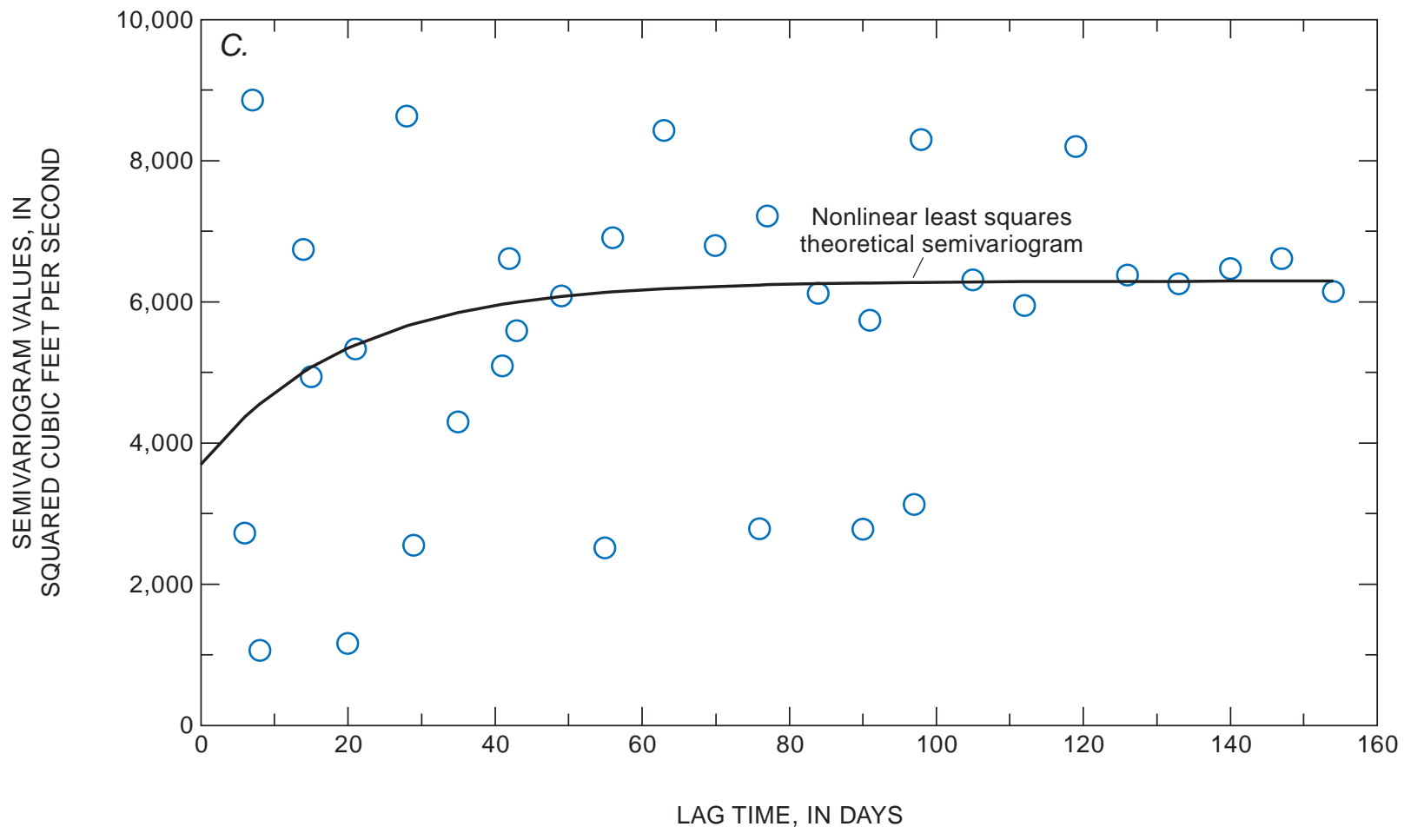

Figure 29. Continued. 


\section{APPLICATION OF METHODS FOR RESERVOIR-CONTENT GAGING STATIONS}

The change in the reservoir storage component of the LCRAS water balance (equation 1) comprised the change in reservoir content measured for Lake Mohave and Lake Havasu. The sum of the change in content of Martinez Lake, Mittry Lake, and Senator Wash Reservoir was a minor part of the overall change in reservoir storage of the lower Colorado River. The contents of Lake Mohave and Lake Havasu are monitored by gaging stations operated by the USGS. The USGS reports daily values of the reservoir-surface elevation at midnight of each day and the usable reservoir content corresponding to that elevation.

\section{Lake Mohave}

The reservoir-content gaging station for Lake Mohave (site 2, figs. 1 and 2) is on the forebay structure on the east side of Davis Dam and is operated by the USGS. Reservoir contents for 1995-99 were computed on the basis of a reservoir stage-content rating that was developed in 1949 by the BOR. Reservoir stage was monitored continuously by a float-tape gage in a stilling well $70 \mathrm{ft}$ upstream from the center-line of penstock number 1 and $8.5 \mathrm{ft}$ from the center-line of the dam.

The standard error of a reservoir-stage reading as discussed in the methods section was $0.073 \mathrm{ft}$. The variance of estimate of the annual change in content for years 1995-99 was determined by using equation 17, the stated standard error of single reservoir-stage readings, and the reservoir-surface area for the beginning and ending reservoir-stage readings (table 17).

Table 17. Summary of error-analysis results for the annual change in content of Lake Mohave

\begin{tabular}{ccccc}
\hline Year & $\begin{array}{c}\text { Change in content, } \\
\text { in acre-feet }\end{array}$ & Change in stage, in feet & $\begin{array}{c}\text { Variance of estimate of } \\
\text { change in content, } \\
\text { in (acre-feet) }\end{array}$ & $\begin{array}{c}\text { Standard error of change } \\
\text { in content, in acre-feet }\end{array}$ \\
\hline 1995 & $-19,000$ & -0.70 & $7,770,000$ & 2,790 \\
1996 & $-46,000$ & -1.72 & $7,487,000$ & 2,740 \\
1997 & 123,000 & 4.55 & $7,487,000$ & 2,740 \\
1998 & $-173,000$ & -6.45 & $7,487,000$ & 2,740 \\
1999 & 54,000 & 2.05 & $7,487,000$ & 2,740 \\
\hline
\end{tabular}

\section{Lake Havasu}

The reservoir-content gaging station for Lake Havasu (site 7, figs. 1 and 2) is on the downstream side of the pumping plant for the Colorado River Aqueduct, $1.8 \mathrm{mi}$ upstream from Parker Dam, and is operated by the USGS. Reservoir contents for 1995-99 were computed on the basis of a stage-content rating that was originally developed in 1930 and later revised following a resurvey of the Lake between elevations 440 and $450 \mathrm{ft}$ in 1957 . The revised tables were significantly different than the original tables and were first used for water year 1958 records computation. Reservoir content data for water years prior to 1958 have not been revised. Stage was monitored continuously with a float-type gage in a stilling well.

The standard error of a reservoir-stage reading as discussed in the methods section was $0.060 \mathrm{ft}$. The variance of estimate of the annual change in content for years 1995-99 was determined by using equation 17, the stated standard error of single reservoir-stage readings, and the reservoir-surface area for the beginning and ending reservoir-stage readings (table 18). 
Table 18. Summary of error-analysis results for the annual change in content of Lake Havasu

\begin{tabular}{ccccc}
\hline Year & $\begin{array}{c}\text { Change in content, } \\
\text { in acre-feet }\end{array}$ & Change in stage, in feet & $\begin{array}{c}\text { Variance of estimate of } \\
\text { change in content, } \\
\text { in (acre-feet) }\end{array}$ & $\begin{array}{c}\text { Standard error of change } \\
\text { in content, in acre-feet }\end{array}$ \\
\hline 1995 & $-24,600$ & -1.30 & $2,572,000$ & 1,600 \\
1996 & 600 & 0.03 & $2,545,000$ & 1,590 \\
1997 & 43,700 & 2.28 & $2,712,000$ & 1,650 \\
1998 & 5,800 & 0.29 & $2,880,000$ & 1,700 \\
1999 & $-62,600$ & -3.28 & $2,606,000$ & 1,610 \\
\hline
\end{tabular}

\section{SUMMARY OF UNCERTAINTY IN THE ANNUAL DISCHARGE AND THE ANNUAL CHANGE IN RESERVOIR CONTENT}

Streamflow- and reservoir-contents gaging stations in the LCRAS network are used to reduce the uncertainty in estimates of the consumptive use of Colorado River water used by diverters. The performance of each gaging station at reducing this uncertainty is, in part, dependent on the accuracy of the data generated by the gaging station. Other factors also are important, such as whether the gaging station is positioned at the appropriate location in the hydrologic system, and whether the gaging station is capable of monitoring the hydrologic phenomenon that it was intended to measure under all conditions that may be present. The performance of a gaging station at producing accurate data can be evaluated by examining the standard error of the annual discharge as a percentage. The performance at producing accurate data, in the context of the LCRAS, however, can be evaluated by examining the variance of estimate of the annual discharge, because this is the statistic that is used to distribute the residual of the LCRAS water balance (equation 1).

The standard error of the annual discharge for years 1995-99 was generally small compared to the annual discharge for most stations, and ranged from 0.11 percent for the All-American Canal near Imperial Dam in 1998 to 12.26 percent for the Colorado River below Imperial Dam in 1996 (figs. 30-32). The modified Moss and Gilroy method requires the assumption of unbiased discharge-rating residuals, and for this reason, the standard errors presented in this report only represent the random error in the annual discharge data. With the exceptions of Bill Williams River below Alamo Dam; Gila River near Dome; and the desilting-basin discharges, seepage, and leakage for the Colorado River below Imperial Dam, the standard error of the annual discharge was less than 2 percent. The large standard error of the annual discharge, as a percentage, for the desilting-basin discharges, seepage, and leakage for the Colorado River below Imperial Dam can mostly be attributed to errors in the seepage and leakage rather than errors in the desilting-basin discharges, because the desilting-basin discharges are measured and the seepage and leakage were estimated as a constant discharge. The standard error of the annual discharge, as a percentage, for the streamflow-gaging stations on the Bill Williams and Gila Rivers was large because their channels are unstable and, therefore, the discharge-ratings were unstable. The Colorado River at the NIB has an unstable channel and, therefore, an unstable discharge-rating; however, the standard error of the annual discharge, as a percentage, was small because of the high measurement frequency (about 200 measurements per year). The Colorado River below Davis and Parker Dams, Mittry Lake diversions, the Gila Gravity Main Canal at Imperial Dam (AVM gaging station), Wellton-Mohawk Canal (both gaging stations), and All-American Canal near Imperial Dam and below Pilot Knob have the smallest standard errors, as a percentage, because the dischargeratings were generally stable. Of these stations, the two on the All-American Canal have the smallest standard error of the annual discharge, as a percentage, in part, because of the high discharge measurement frequency.

For the LCRAS, the variance of estimate of the annual discharge is an important statistic to examine because the residual of the water balance (equation 1) is distributed amongst the components of the water balance on the basis of the variance of estimate of that component. The variance of estimate for the annual discharge ranged from 9,430 acre- $\mathrm{ft}^{2}$ for the Mittry Lake Diversions in 1995 to 6,040 million acre- $\mathrm{ft}^{2}$ for the Colorado River at the NIB in 1998 (fig. 33). Although the standard error of the annual discharge, as a percentage, was smallest at streamflowgaging stations on the main stem of the Colorado River; however, the variance of estimate of the annual discharge, in squared acre-feet, was largest at these stations because of the large annual discharge on the main stem (figs. 32 and 33). 


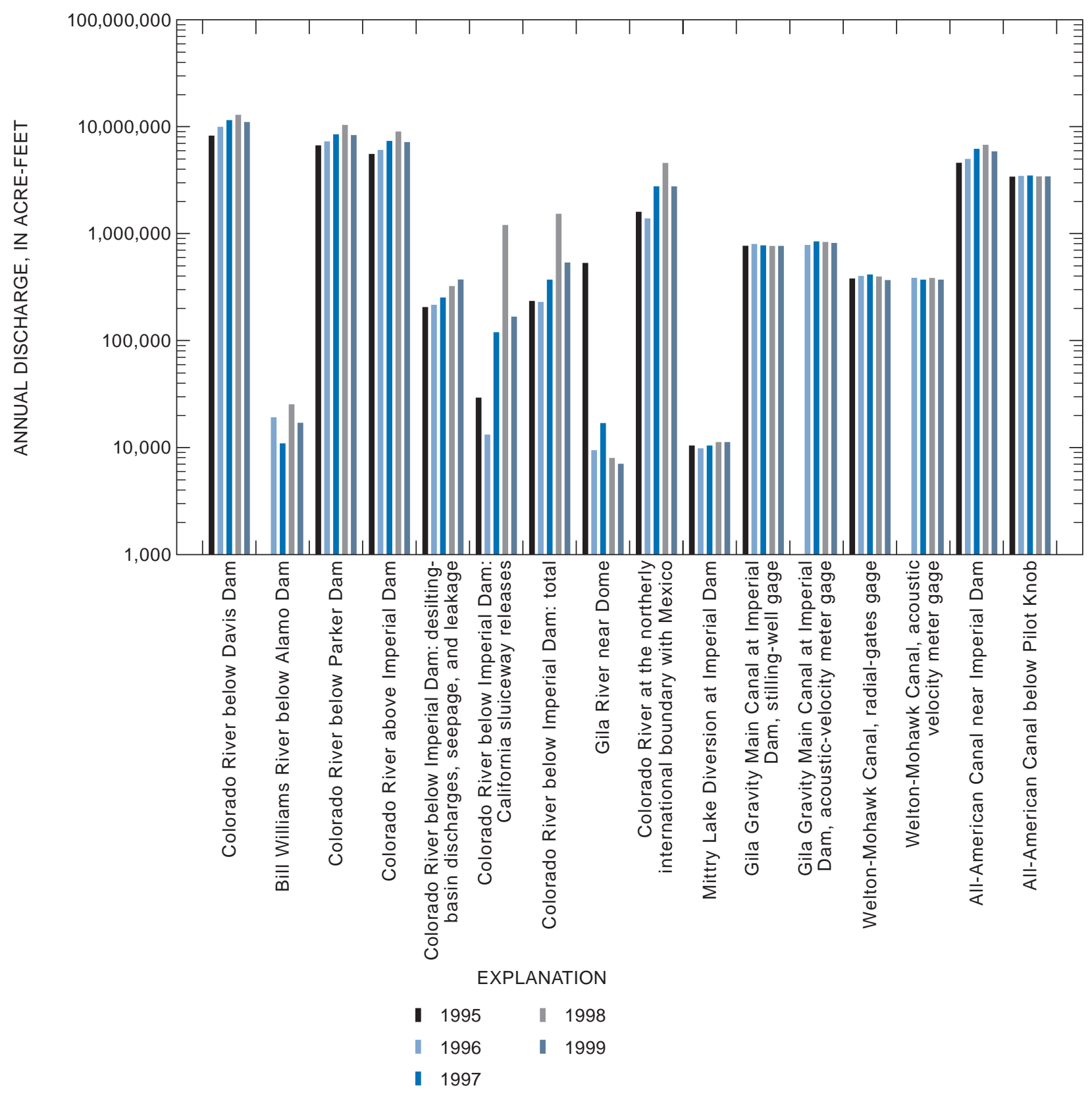

Figure 30. Annual discharge at streamflow-gaging stations 1995-99. 


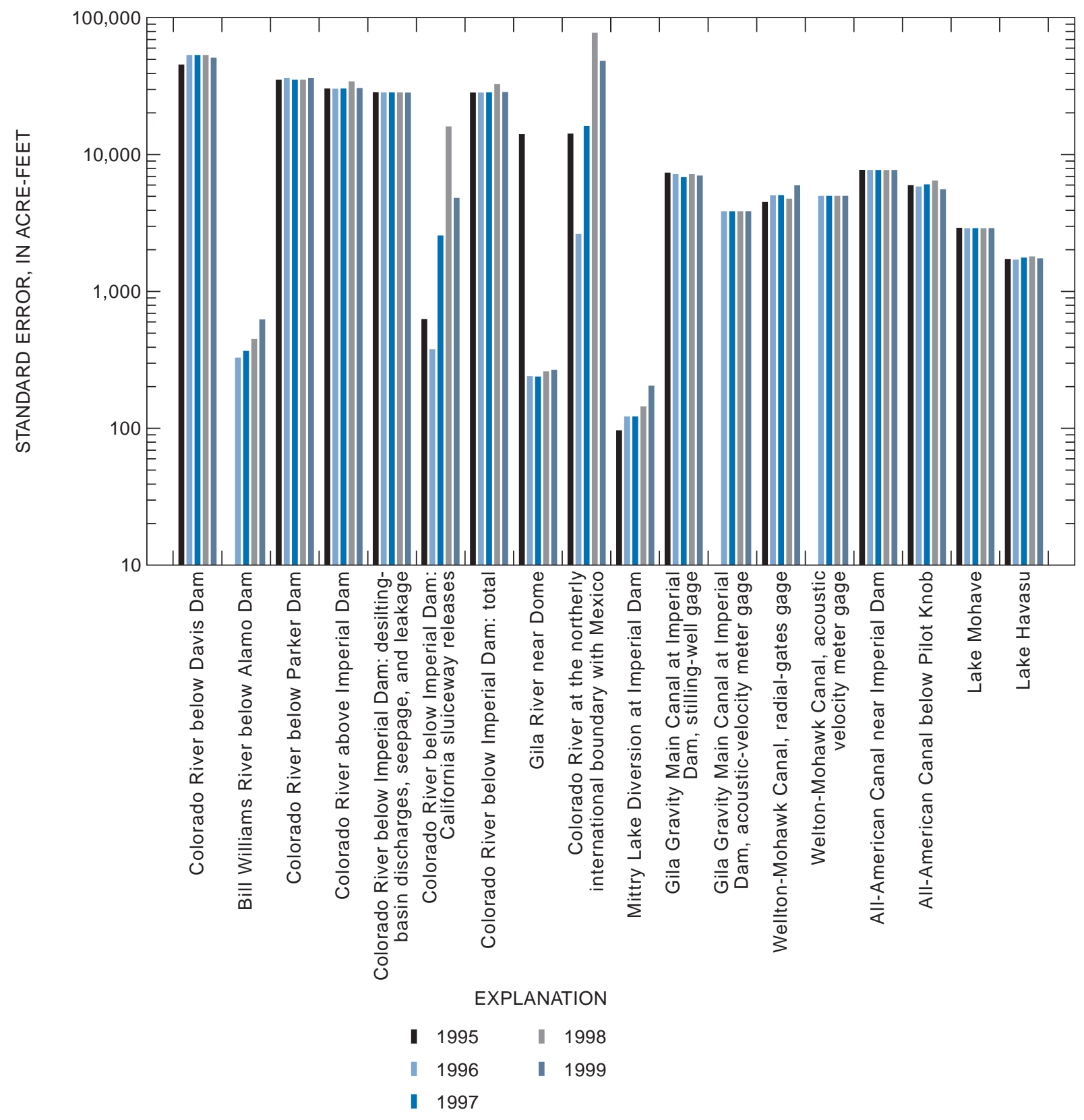

Figure 31. Standard error of the annual discharge and of the annual change in reservoir content at surface-water gaging stations, 1995-99. 


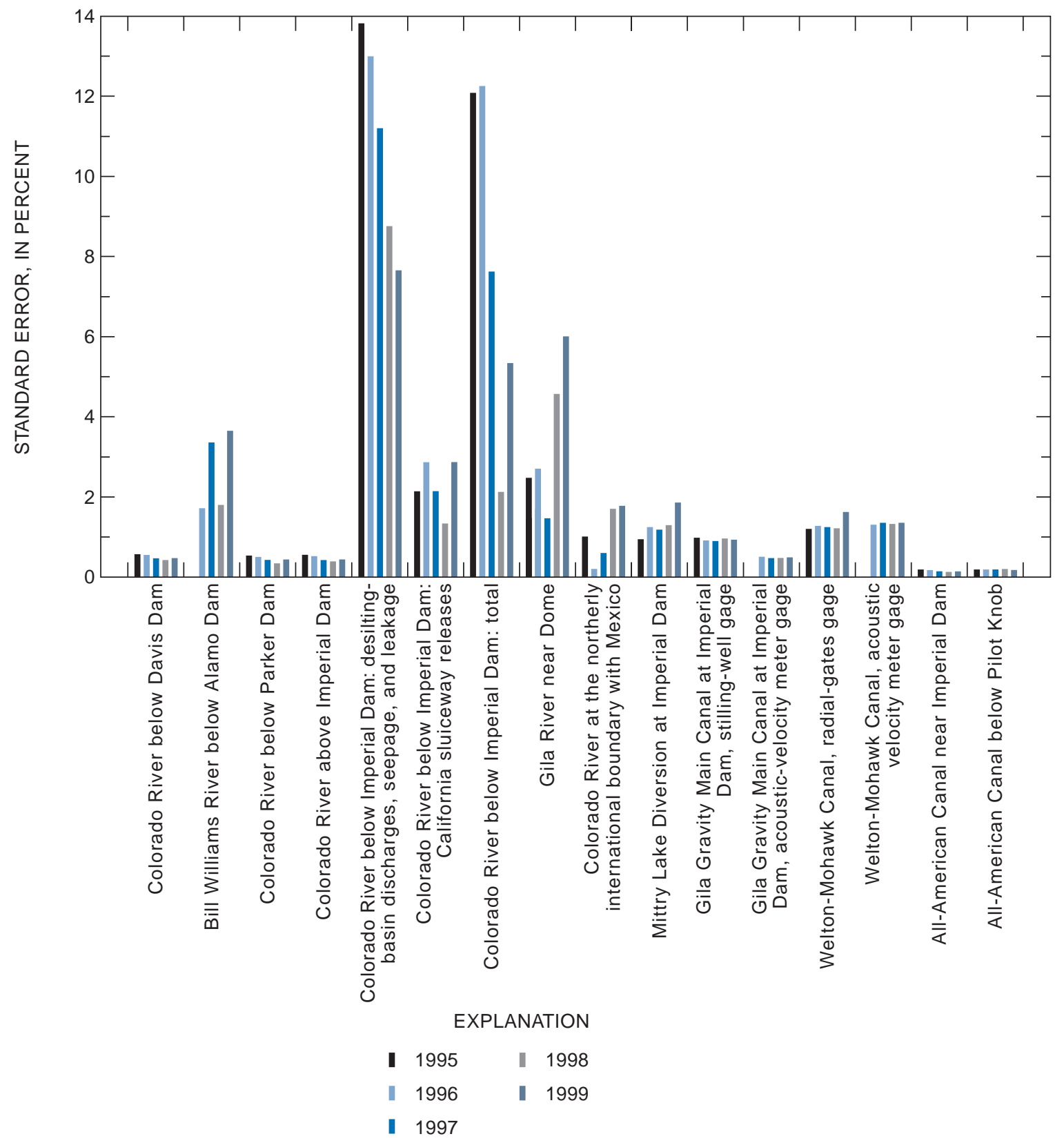

Figure 32. Standard error of the annual discharge, as a percentage, at streamflow-gaging stations, 1995-99. 


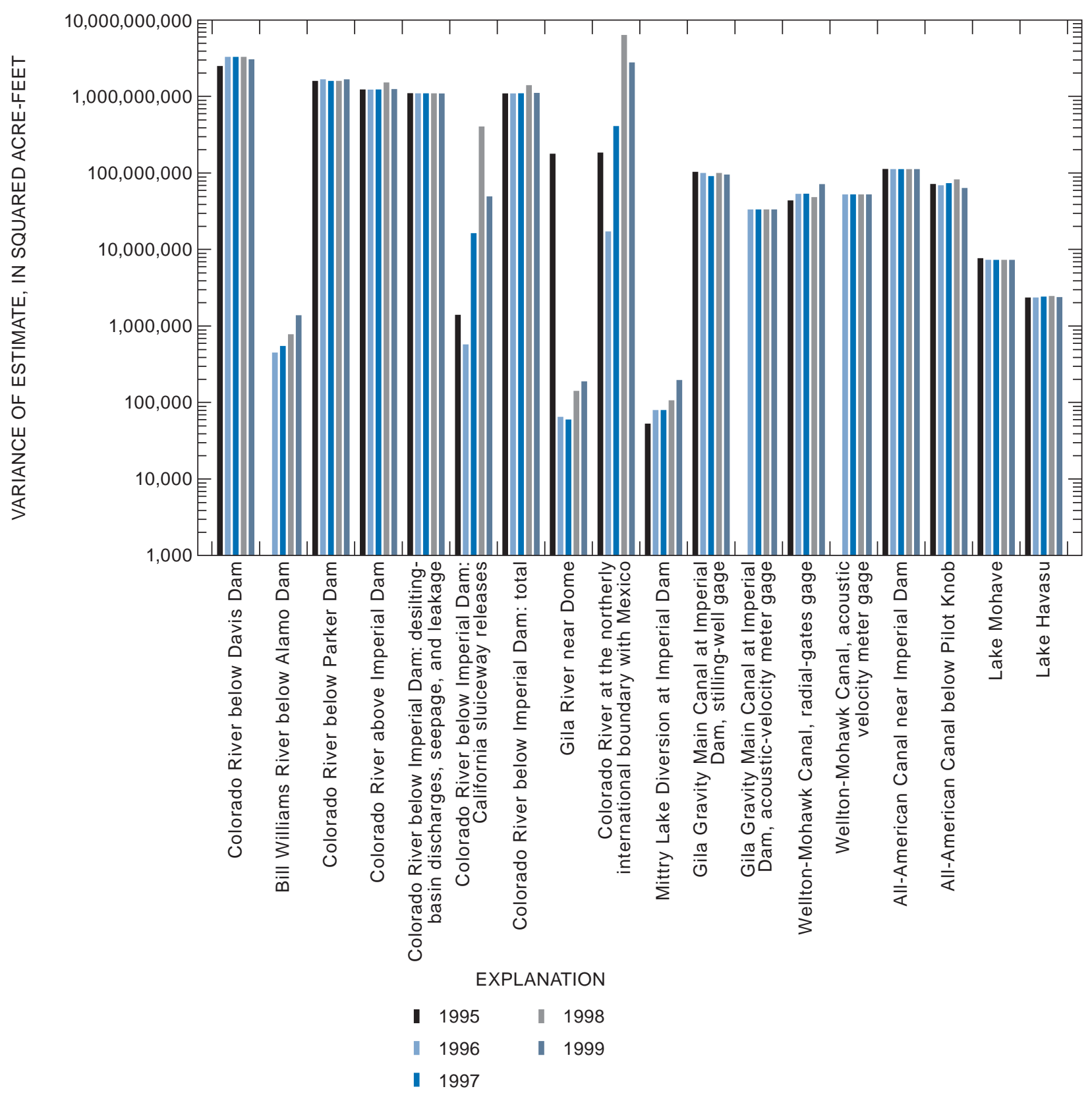

Figure 33. Variance of estimate of the annual discharge and of the annual change in reservoir content at surface-water gaging stations, 1995-99.

The variance of estimate of the annual change in reservoir content for the two reservoir-content gaging stations was generally smaller than the variance of estimate for the annual discharge for streamflow-gaging stations on the main stem of the Colorado River and major diversions from the Colorado River; however, it was generally larger than the variance of estimate for the annual discharge for most of the streamflow-gaging stations measuring tributary inflows to the Colorado River (fig. 33). The variance of estimate for the annual change in content for the two reservoirs ranged from 2.545 million acre- $\mathrm{ft}^{2}$ for Lake Havasu in 1996 to 7.770 million acre- $\mathrm{ft}^{2}$ for Lake Mohave in 1995. 


\section{UNCERTAINTY-REDUCING STREAMFLOW-GAGING STRATEGIES}

Reducing the uncertainty in the annual discharge would increase the accuracy of the measurements of flow used in the LCRAS, and contribute to the overall reliability of the LCRAS, which would ultimately benefit the water users. For the purpose of distributing the LCRAS water balance residual (equation 1), stations with the largest variance of estimate for the annual discharge within an LCRAS reach should have the highest priority for error reduction. These stations, in order of largest to smallest average annual variance of estimate for 1995-99, are Colorado River below Davis Dam, Colorado River at the NIB, Colorado River below Parker Dam, Colorado River above Imperial Dam, and Colorado River below Imperial Dam (fig. 33). The uncertainty in the annual discharge at most of the streamflow-gaging stations could be reduced by improving the streamflow-gaging strategies. These strategies fall into two categories, those that reduce process variance and those that reduce measurement variance.

\section{Streamflow-Gaging Strategies that Reduce Process Variance}

Uncertainty in computed discharge that results from the physical processes that generate process variance in the discharge-rating residuals can be reduced either by mitigating the physical processes, or by increasing the discharge measurement frequency. In general, mitigating the physical process is difficult and expensive; for instance, the effects of an unstable stream channel on the uncertainty of computed discharges can be mitigated by installing a control structure. For many cases, increasing the frequency of discharge measurements is a more practical streamflow-gaging strategy for reducing uncertainty in computed discharges. The largest reduction of the variance of estimate of the annual discharge per added discharge measurement per year is realized at the lowest discharge measurement frequencies (fig. 14). For example, if the discharge-measurement frequency at a station was increased from 6 times per year to 12 times per year, the reduction of the variance of estimate of the annual discharge would be more than if the discharge-measurement frequency at the same station was increased from 12 times per year to 18 times per year. For most stations in the LCRAS network, increasing the dischargemeasurement frequency would result in a noticeable decrease in the standard error of the annual discharge. For AllAmerican Canal near Imperial Dam, All-American Canal below pilot Knob, and Colorado River at the NIB, however, which have about 50, 100, and 200 discharge measurements made per year, respectively, the standard error of the annual discharge, as a percentage, does not decrease significantly per added measurement (figure 14 for Colorado River at the NIB).

The streamflow-gaging strategy implemented during 1995-99 for the desilting-basin discharges, seepage, and leakage for the Colorado River below Imperial Dam did not address the process error. The uncertainty in the annual discharge for the desilting-basin discharges, seepage, and leakage propagates into the uncertainty in the annual discharge for Colorado River below Imperial Dam and Colorado River above Imperial Dam; therefore, reducing the uncertainty in the annual discharge for the desilting-basin discharges, seepage, and leakage also reduces the uncertainty in the annual discharge for the other two stations. The uncertainty in the annual discharge for the desilting-basin discharges, seepage, and leakage could be reduced by using an estimate of the seepage and leakage that varies over time rather than by using a constant estimate of $50 \mathrm{ft}^{3} / \mathrm{s}$. Seepage and leakage on days the discharge is measured would be estimated as the measured flow minus the reported flow for the desilting-basin discharges (with the condition that all California sluiceway gates are closed). The seepage and leakage for days on which discharge was not measured would be interpolated between days on which discharge was measured. If this proposed streamflow-gaging strategy was implemented for 12 discharge measurements (with the California sluiceway gates closed) per year, then the variance of estimate of the annual discharge for the desilting-basin discharges, and seepage and leakage could be decreased by almost 800 million acre- $\mathrm{ft}^{2}$ and the standard error of the annual discharge, as a percentage, could be decreased almost an order of magnitude (table 19). This proposed streamflow-gaging strategy would decrease the variance of estimate of the annual discharge for Colorado River below Imperial Dam and Colorado River above Imperial Dam by almost 800 million acre- $\mathrm{ft}^{2}$, and the standard error of the annual discharge, as a percentage, could be decreased from 0.45 to 0.18 percent and from 7.88 to 1.36 percent, respectively. Note that since 1995 , no discharge measurements have been made while the California sluiceway gates were closed, so operating the streamflow-gaging stations under this improved strategy would also require making additional discharge measurements. 
Table 19. Average annual variance of estimate and standard error of the annual discharge, 1995-99, at selected streamflow-gaging stations based on the existing streamflow-gaging strategy and on a proposed streamflow-gaging strategy

\begin{tabular}{|c|c|c|c|}
\hline \multirow[b]{2}{*}{ Streamflow-gaging strategy } & \multirow{2}{*}{$\begin{array}{l}\text { Average variance of estimate } \\
\text { of the annual discharge, } \\
\text { 1995-99 } \\
\text { (acre-feet) })^{2}\end{array}$} & \multicolumn{2}{|c|}{$\begin{array}{l}\text { Average standard error of } \\
\text { the annual discharge, 1995- } \\
99\end{array}$} \\
\hline & & Acre-feet & Percent \\
\hline \multicolumn{4}{|c|}{ Colorado River above and below Imperial Dam } \\
\hline \multicolumn{4}{|c|}{ Desilting-basin discharges, seepage, and leakage } \\
\hline $\begin{array}{l}\text { Existing streamflow-gaging strategy: discharge for seepage and } \\
\text { leakage below California spillway is a constant discharge of } 50 \mathrm{ft}^{3} / \mathrm{s}\end{array}$ & $800,400,000$ & 28,700 & 10.88 \\
\hline $\begin{array}{l}\text { Proposed streamflow-gaging strategy: discharge for seepage and leakage } \\
\text { below the California spillway varies over time as determined on the basis } \\
\text { of } 12 \text { discharge measurements per year }\end{array}$ & $11,640,000$ & 3,410 & 1.31 \\
\hline Error reduction & $788,760,000$ & 25,290 & 9.57 \\
\hline \multicolumn{4}{|c|}{ Colorado River below Imperial Dam } \\
\hline $\begin{array}{l}\text { Existing streamflow-gaging strategy: discharge for seepage and } \\
\text { leakage below California spillway is a constant discharge of } 50 \mathrm{ft}^{3} / \mathrm{s}\end{array}$ & $857,300,000$ & 29,230 & 7.88 \\
\hline $\begin{array}{l}\text { Proposed streamflow-gaging strategy: discharge for seepage and leakage } \\
\text { below the California spillway varies over time as determined on the basis } \\
\text { of } 12 \text { discharge measurements per year }\end{array}$ & $68,550,000$ & 6,670 & 1.25 \\
\hline Error reduction & $788,750,000$ & 22,560 & 6.63 \\
\hline \multicolumn{4}{|c|}{ Colorado River above Imperial Dam } \\
\hline $\begin{array}{l}\text { Existing streamflow-gaging strategy: discharge for seepage and } \\
\text { leakage below California spillway is a constant discharge of } 50 \mathrm{ft}^{3} / \mathrm{s}\end{array}$ & $966,900,000$ & 31,060 & 0.45 \\
\hline $\begin{array}{l}\text { Proposed streamflow-gaging strategy: discharge for seepage and leakage } \\
\text { below the California spillway varies over time as determined on the basis } \\
\text { of } 12 \text { discharge measurements per year }\end{array}$ & $178,200,000$ & 12,950 & 0.18 \\
\hline Error reduction & $788,700,000$ & 18,110 & 0.27 \\
\hline \multicolumn{4}{|c|}{ Gila Gravity Main Canal at Imperial Dam (acoustic velocity meter gage) } \\
\hline Existing streamflow-gaging strategy: discharge rating is not shifted & $14,890,000$ & 3,860 & 0.47 \\
\hline $\begin{array}{l}\text { Proposed streamflow-gaging strategy: discharge rating is shifted on the } \\
\text { basis of } 12 \text { discharge measurements per year }\end{array}$ & $10,210,000$ & 3,190 & 0.39 \\
\hline Error reduction & $4,680,000$ & 670 & 0.08 \\
\hline \multicolumn{4}{|c|}{ Wellton-Mohawk Canal (acoustic velocity meter gage) } \\
\hline Existing streamflow-gaging strategy: discharge rating is not shifted & $24,860,000$ & 4,990 & 1.32 \\
\hline $\begin{array}{l}\text { Proposed streamflow-gaging strategy: discharge rating is shifted on the } \\
\text { basis of } 12 \text { discharge measurements per year }\end{array}$ & $4,042,000$ & 2,010 & 0.53 \\
\hline Error reduction & $20,818,000$ & 2,980 & 0.79 \\
\hline
\end{tabular}

The streamflow-gaging strategies implemented during 1996-99 for the Gila Gravity Main Canal at Imperial Dam and Wellton-Mohawk Canal AVM gages did not address process error. The uncertainty in the annual discharge for these stations could be reduced by shifting the discharge rating on the basis of the monthly discharge measurements at those streamflow-gaging stations. If discharge-rating shifts were applied, in units of discharge, the variance of estimate of the annual discharge would be reduced by about 5 million acre- $\mathrm{ft}^{2}$ and 21 million acre- $\mathrm{ft}^{2}$, respectively, for Gila Gravity Main Canal at Imperial Dam and Wellton-Mohawk Canal (table 19). Also, any bias in the discharge rating as indicated by temporal trends in the discharge-rating residuals, such as that previously described for the Wellton-Mohawk Canal (AVM), would be removed from the computed discharges. Although the decreases in the variance of estimate of the annual discharge are not as large as those shown for other stations, this proposed stream-gaging strategy may be cost effective because it does not require making additional discharge measurements. 


\section{Streamflow-Gaging Strategies that Reduce Measurement Variance}

The uncertainty in the annual discharge can also be reduced by using streamflow-gaging strategies that reduce measurement variance. Measurement variance results from uncertainty in the discharge measurements and the gage-height and gate-opening readings. Any reduction of uncertainty in these measurements will lead to a reduction in the uncertainty in the annual discharge. The uncertainty in an individual discharge measurement can be reduced by increasing the number of sections at which depth and velocity are measured, or by increasing the observation time for the velocity measurements (Carter and Anderson, 1963). These increases require more time to measure the discharge, time which may be better spent making a second measurement immediately after the first, and then averaging the two discharges. Assuming the same uncertainty for the two discharge measurements and a steady river stage, the measurement variance for this averaged discharge would be half that for a single discharge measurement.

The optimal site-visit and discharge-measurement strategy that minimizes the variance of estimate of the annual discharge will vary by streamflow-gaging station depending on the ratio of measurement variance to process variance, the serial correlation of the discharge-rating residuals, and the travel costs associated with making discharge measurements. Suppose, for example, that operating a streamflow-gaging station by using a strategy of 24 site visits with a single discharge measurement costs the same as using a strategy of 18 site visits with two consecutive discharge measurements. For stations where measurement variance is much greater than the process variance and the serial correlation of the discharge-rating residuals is high, the optimal strategy would involve making multiple discharge measurements per site visit and less site visits. For example, the variance of estimate of the annual discharge for Colorado River below Davis Dam for 18 site visits per year with two measurements per visit is less than the variance of estimate of the annual discharge for 24 single-discharge measurement site visits per year (fig. 34). In contrast, for stations where process variance is much greater than measurement variance and the serial correlation of the discharge-rating residuals is low, the stream-gaging strategy would consist of single discharge measurement site visits, but more site visits. For example, operating the stilling-well gage at Gila Gravity Main Canal at Imperial Dam with a strategy of 24 single-discharge measurement site visits per year would result in a smaller variance of estimate of the annual discharge than a strategy of 18 site visits per year with two discharge measurements per site visit (fig. 34). In summary, for a given operating cost or for a given variance of estimate of the annual discharge at a streamflow-gaging station, the optimal site-visit and discharge-measurement strategy can be determined, providing that the travel costs as well as the measurement variance, process variance, and serial correlation of discharge-rating residuals are known.

Uncertainty in the gage height and (or) gate openings associated with a discharge measurement also contribute to the measurement variance. Any physical improvements that reduce the uncertainty in these gage-height or gateopening readings will decrease the measurement variance. For gage-height readings, the source of uncertainty generally is not the precision of the markings on the staff plate or wire weight, but rather, uncertainty results from difficulties observing the gage height either because of its distance from the observing location or because of a surging water surface. The measurement error of the radial-gates gage at the Wellton-Mohawk Canal could be reduced by replacing the gate-opening indicator with a more precise and easier to read plate. At present (2001) the standard error of gate-opening readings from the indicator is about $0.05 \mathrm{ft}$. An improved gate-opening indicator would reduce the measurement error, and, therefore, the uncertainty in the annual discharge.

\section{Improvements for Standard-Error Estimates}

The estimates of the standard error of the annual discharge and annual change in reservoir content can be improved. The quality of the error estimates can be improved by either improving the quality of the input parameters used in the error estimation methods, or modifying the error estimation methods so that certain circumstances present at the gaging stations are accounted for rather than neglected. 


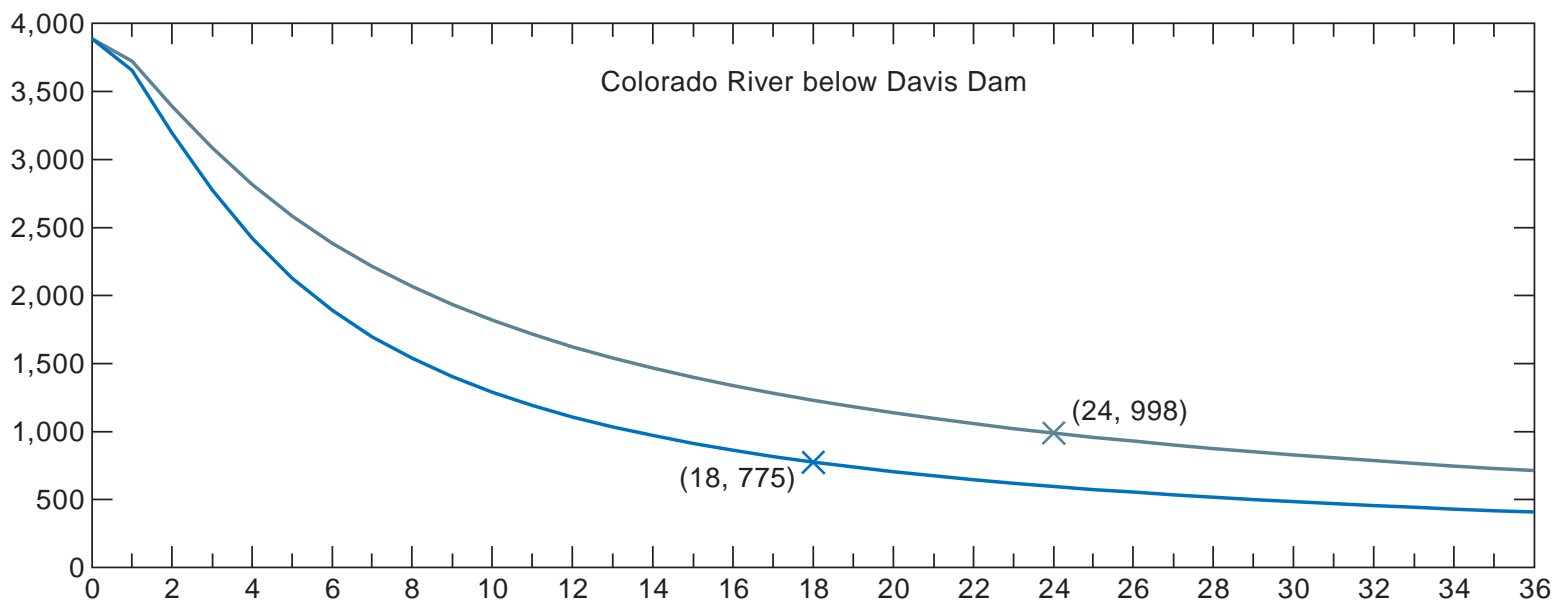

NUMBER OF SITE VISITS PER YEAR

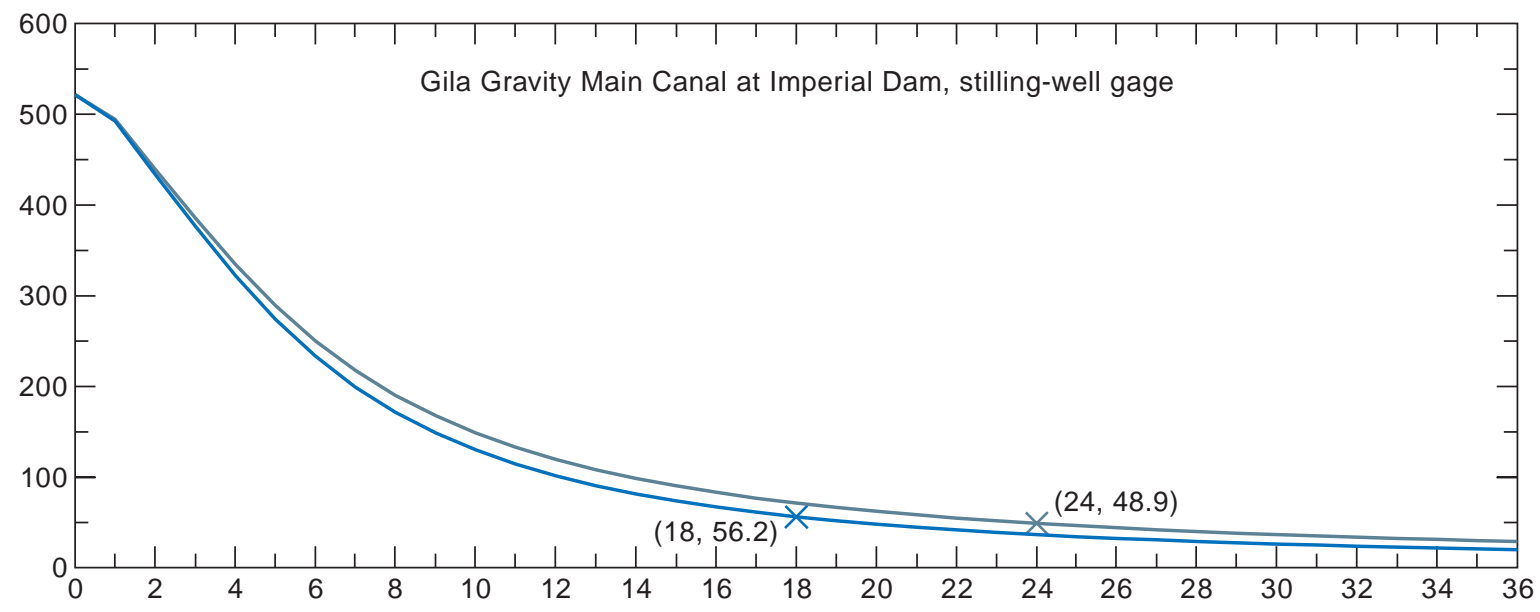

NUMBER OF SITE VISITS PER YEAR

\section{EXPLANATION}

Number of discharge measurements used per site visit for determining shift

\section{One}

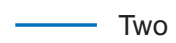

Figure 34. Comparison of the variance of estimate of the annual discharge for the discharge-rating shift determined on the basis of one or two discharge measurements per site visit. 
The quality of error estimates for the change in reservoir content is dependent on the quality of the estimate of the standard error of a reservoir-stage reading. The approach used in this investigation to estimate the standard error of a reservoir-stage reading may not fully account for a spatially varying elevation of the reservoir surface. The uncertainty in a reservoir stage reading that results from spatial variations in the reservoir-surface elevation could be determined by monitoring differences between the reservoir-surface elevation measured at the gaging station and the reservoir-surface elevation that is measured by a network of several gaging stations that are spatially dispersed about the reservoir.

The modified Moss and Gilroy method generally was well suited for the conditions at the streamflow-gaging stations in this study. There were, however, cases where the methods were not perfectly suited for the conditions. The method requires that the discharge measurements be representative of the discharges for the station. This generally is not an issue for stations on the main stem of the Colorado River or on canals; however, in some years it can be an issue for Bill Williams River below Alamo Dam and Gila River near Dome. At these two stations occasional high-flow events constitute most of the annual discharge. During these events, a sufficient number of discharge measurements must be made to generate semivariograms that adequately represent larger discharges. Another shortcoming is the assumption that changes in the relation between discharge and the correlative variable result in a shift of the entire discharge rating by a constant quantity. The method does not account for shifts that are applied to specific ranges in discharge of the discharge rating nor changes in the slope of the relation between discharge and the correlative variable over time. In practice, the discharge ratings at some stations are shifted by a multiplicative factor rather than by adding a shift. This is the case for the releases through the California Sluiceway gates for the Colorado River below Imperial Dam, Mittry Lake Diversion at Imperial Dam, Wellton-Mohawk Canal (radial-gates gage), and All-American Canal below Pilot Knob. For these stations, estimates of the standard error of the annual discharge should still be fairly reliable because the problem associated with the multiplicative shift affects uncertainty in the annual discharge resulting from process error, not measurement error, and at these stations the process error was generally small compared to the measurement error. Another shortcoming of the method is that the effects of inconsistent time intervals between discharge measurements within a year is not considered. Generally, this was not an issue, except at the Colorado River below Davis Dam; within some years the number of days between measurements ranged from less than 30 to more than 120 .

The quality of the estimates of the standard error of the annual discharge also is dependent on the quality of the estimates for measurement variance, process variance, and the one-day serial-correlation coefficient. For good estimates of the measurement variance, process variance, and the one-day serial-correlation coefficient, the time interval between discharge measurements must be shorter than the correlation time for the discharge-rating residuals for the station. For cases in which the time interval between consecutive discharge measurements is longer than the correlation time for the discharge-rating residuals, the accuracy of the estimates of these three parameters is limited because the parameter values must be estimated in a subjective manner by manually fitting the theoretical semivariograms. The estimates of these parameters can be improved by increasing the frequency of discharge measurements. Estimates of measurement variance can be improved by making more than one discharge measurement while visiting the gaging station - this would result in values at zero days lag on the semivariogram (fig. 12). The measurement variance determined from the semivariogram, however, could be underestimated if there are systematic errors in the multiple discharge measurements made during a given site visit. Streamflowgaging stations with the largest variance of estimate of the annual discharge, such as Colorado River below Davis Dam and Colorado River below Parker Dam, would be of higher priority to improve estimates of the measurement variance, process variance, and one-day correlation-coefficient than those with smaller variance of estimate of the annual discharge. 
Use of semivariograms to estimate measurement variance is a good alternative to use of an empirical method [such as the Carter and Anderson (1963), or Sauer and Meyer (1992)] as was used in the original Moss and Gilroy method (1980). For nine discharge ratings (seven stations), measurement variance determined on the basis of the error in individual discharge measurements as estimated by using the Sauer and Meyer method was larger than measurement variance determined by using information from the semivariograms (fig. 35). For the Colorado River below Davis Dam, Colorado River below Parker Dam, Mittry Lake Diversion at Imperial Dam, All-American Canal near Imperial Dam, and All-American Canal below Pilot Knob, measurement variance determined on the basis of the error in individual discharge measurements as estimated by using the Sauer and Meyer method was greater than the variance of the discharge-rating residuals. For these stations, measurement variance determined on the basis of the error in individual discharge measurements as estimated by using the Sauer and Meyer method clearly are overestimated - the measurement variance must be equal to or less than the variance of the residuals (equation 9). The Sauer and Meyer method may overestimate the error in individual discharge measurements at these stations because the stations have trapezoidal cross sections with smooth, uniform and stable bottoms; no mid-channel obstructions (brush or boulders); and depths greater than $2.5 \mathrm{ft}$ (except Mittry Lake Diversion at Imperial Dam). These conditions, conceptually, should result in small measurement errors because of good conditions for measuring cross-sectional area, and the velocities should be nonpulsating and smoothly distributed across the measuring section. The measurement variance determined by the semivariograms is considered a more accurate estimate of the measurement error because it is determined on the basis of the discharge-measurement data, rather than on the basis of theoretical errors determined on the basis of conditions of the discharge measurement.

The Kalman-filter theory used by the modified Moss and Gilroy method requires the assumption of unbiased discharge-rating residuals because the mathematics of the filter do not account for bias. For this reason, the standard errors presented in this report only represent the random error in the annual discharge data. In general, bias is difficult to detect and quantify, and if bias is quantified then usually the data should be corrected. Bias in computed discharges may result from bias in the discharge measurements used to compute discharge, or from the methods used to compute the discharge. For streamflow-gaging stations used in the LCRAS, there are at least three methods of detecting bias. The first method is to examine residuals from the LCRAS water balance (equation 1; Bureau of Reclamation, 2000). The second method is to compare discharge data for redundant streamflow-gaging stations. The third method is to examine data-collection procedures and computation methods that may lead to bias in the computed discharge record.

A qualitative examination of the water-balance equation residuals from the four independent LCRAS reaches for 1995-99 indicates that three of the four reaches may have biased residuals (table 20). The small sample size (only 5 years) and the lack of consistent procedures for computing all the terms in the water balance for all 5 years precluded a rigorous statistical analysis of the water balance residuals.

The water balance residuals for the Hoover Dam to Davis Dam reach were negative for 4 out of 5 years and had a mean of $-73,870$ acre-ft, which indicated a possible small negative bias. The water balance residuals for the Davis Dam to Parker Dam reach were negative for all 5 years and had mean of $-166,500$ acre-ft, which also indicated a possible small negative bias. In contrast, the residuals for the Imperial Dam to Mexico reach were positive for 4 out of 5 years and had a mean of 75,240 acre-ft, which indicated a possible small positive bias. The water balance residuals for Parker Dam to Imperial Dam appeared unbiased with positive values for 3 years, negative values for 2 years, and a mean of 0 acre-ft. Reach residuals with a negative bias indicate that one or more of the reach inflows is negatively biased, or that one or more of the outflows from the reach is positively biased. The opposite is true for reach residuals with a positive bias. Note that the mean residual for each reach represents only a small percentage of the mean inflow at the upstream boundary. 


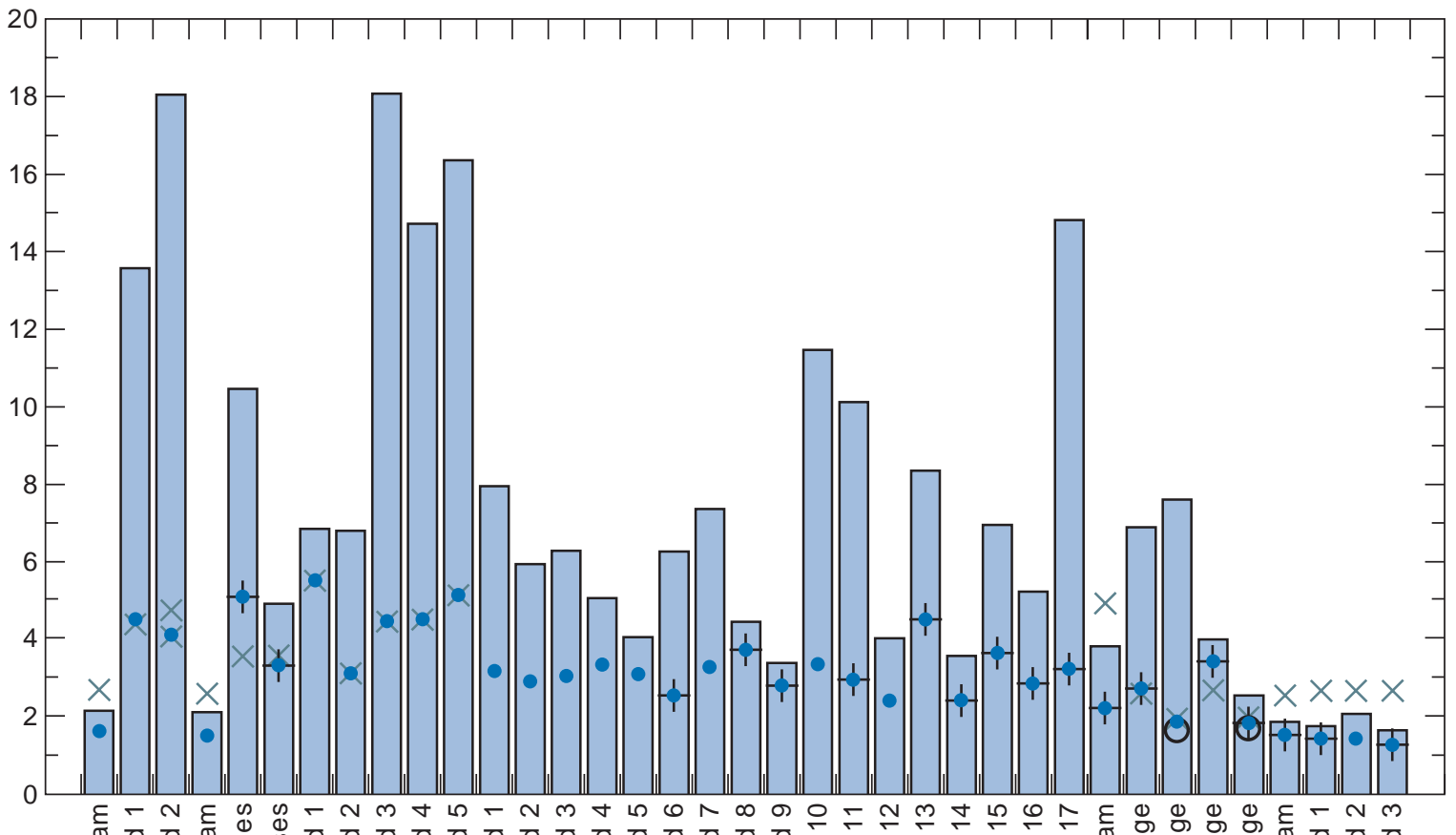

西 듀유

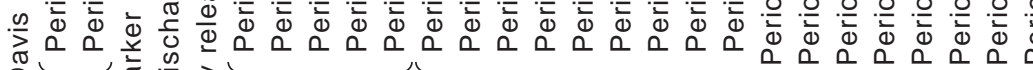

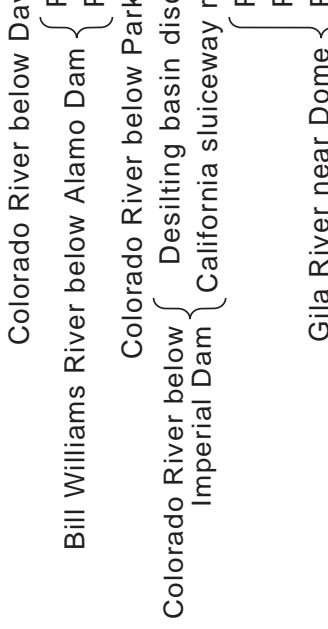

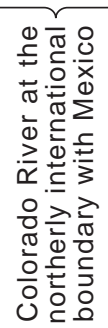

EXPLANATION

Variance of rating residuals

- Measurement variance used for error estimates of the annual discharge

+ Measurement variance determined from semivariogram

$\times$ Measurement variance determined from the Sauer and Meyer method with all measurements

O Measurement variance determined from the truncated sample variance of acoustic doppler current profile measurements

Figure 35. Variance of discharge-rating residuals, measurement variance as determined from the semivariogram, and measurement variance determined from the error of individual discharge measurements as estimated by using the Sauer and Meyer (1992) method. 
Table 20. Residuals from the Lower Colorado River Accounting System, by reach and year

[Data from Bureau of Reclamation, 2000]

\begin{tabular}{|c|c|c|c|c|}
\hline Year & $\begin{array}{l}\text { Hoover Dam to } \\
\text { Davis Dam } \\
\text { (acre-feet) }\end{array}$ & $\begin{array}{l}\text { Davis Dam to } \\
\text { Parker Dam } \\
\text { (acre-feet) }\end{array}$ & $\begin{array}{l}\text { Parker Dam to } \\
\text { Imperial Dam } \\
\text { (acre-feet) }\end{array}$ & $\begin{array}{c}\text { Imperial Dam to } \\
\text { Mexico }\end{array}$ \\
\hline 1995 & 125,800 & $-376,300$ & $-180,500$ & 106,100 \\
\hline 1996 & $-62,470$ & $-198,200$ & 14,050 & 142,600 \\
\hline 1997 & $-94,140$ & $-6,430$ & $-43,780$ & 98,710 \\
\hline 1998 & $-114,500$ & $-81,570$ & 175,100 & 31,370 \\
\hline 1999 & $-224,000$ & $-169,840$ & 35,100 & $-2,520$ \\
\hline Mean residual, in acre-feet & $-73,870$ & $-166,500$ & 0 & 75,240 \\
\hline $\begin{array}{l}\text { Mean residual, as a percentage of the } \\
\text { mean discharge at the upstream } \\
\text { boundary }\end{array}$ & -0.68 & -1.55 & 0.00 & 1.07 \\
\hline Qualitatively determined bias & Negative & Negative & None & Positive \\
\hline
\end{tabular}

Bias also can be detected by comparing discharge data from redundant gaging stations. Bias was detected in the computed instantaneous discharge and annual discharge data for the two gaging stations on the Gila Gravity Main Canal at Imperial Dam and the Wellton-Mohawk Canal. For the two gaging stations on the Gila Gravity Main Canal, the 95-percent confidence interval for the mean difference in the annual discharges for 1996-99 indicated the AVM gage was more positively biased than the stilling-well gage (table 21). The absolute bias for each gaging station cannot be determined from these data alone; therefore, it also cannot be determined which gaging station is reporting an annual discharge closer to the "true" annual discharge. The 95-percent confidence interval for the mean difference of annual discharge for 1996-99 for the two gaging stations on the Wellton-Mohawk Canal almost excludes zero. This indicates a possible difference in the bias for the two streamflow-gaging stations at this site; however, this conclusion cannot be made at the 95-percent confidence level. If data for the AVM gage are corrected for the temporal bias that was indicated by the residuals from the regression equations developed in this investigation (see discussion for the AVM gaging station in the section entitled "Application of the methods for streamflow-gaging stations"), then the means are more similar (table 21). The smaller difference in bias for the corrected data than the uncorrected data supports the stream-gaging strategy of shifting the discharge rating for the AVM gage on the basis of the monthly discharge measurements.

Computed instantaneous discharge for the AVM gage was compared with discharge measured by using vertical-axis current meters by the USGS at the Gila Gravity Main Canal at Imperial Dam and the Wellton-Mohawk Canal (table 21). Similarly, computed instantaneous discharge for the stilling-well gage and the radial-gates gage was compared with discharge measured by the BOR by using a broadband ADCP. The computed instantaneous discharge for the stilling-well gage was less than the discharge measured by using a broadband ADCP at the Gila Gravity Main Canal. These differences were consistent with the differences between the annual discharge for the two gaging stations on the canal. Also consistent with these differences was the fact that the computed instantaneous discharges for the AVM gage were less than discharges measured by using vertical-axis current meters. The difference between discharge computed by using the nonlinear regression equation developed in this study (table 11) for the stilling-well gage and the discharge measured by using a broadband ADCP was similar to the difference between discharge computed by the USGS Yuma field office for the stilling-well gage and the discharge measured by using the broadband ADCP meters. Also, the sample standard deviation of the difference between the discharge computed by the USGS Yuma field office and the discharge measured by using broadband ADCP meters was similar to the standard deviation of the difference between discharge computed with the nonlinear regression equation and the discharge measured by using broadband ADCP meters. The pattern of biases for comparisons of data collected from the gaging stations on the Wellton-Mohawk Canal was similar, except the relative biases were opposite-discharge data for the radial-gates gage was generally larger than discharge data for the AVM gage. The similarity in the relative biases and sample standard deviations between discharge data computed by the USGS Yuma field office and discharge data computed by using the nonlinear regression equation suggests that actual uncertainty in the annual discharge data computed by the USGS Yuma field office should be similar to that determined on the basis of residuals from discharge ratings developed as part of this study. 
Table 21. Comparison of annual discharge data and comparison of measured discharge with computed instantaneous discharge data from the two streamflow-gaging stations on the Gila Gravity Main Canal at Imperial Dam and on Wellton-Mohawk Canal

[AVM, acoustic velocity meter;\%, percent; ADCP, acoustic doppler current profile]

\begin{tabular}{|c|c|c|c|c|c|c|}
\hline & \multicolumn{3}{|c|}{ Gila Gravity Main Canal at Imperial Dam } & \multicolumn{3}{|c|}{ Wellton-Mohawk Canal } \\
\hline & $\begin{array}{l}\text { Cubic feet per } \\
\text { second }\end{array}$ & $\begin{array}{l}\text { Acre-feet per } \\
\text { year }\end{array}$ & Percent $^{1}$ & $\begin{array}{l}\text { Cubic feet per } \\
\text { second }\end{array}$ & $\begin{array}{c}\text { Acre-feet per } \\
\text { year }\end{array}$ & Percent $^{1}$ \\
\hline \multicolumn{7}{|c|}{ Annual discharge, 1996-99 } \\
\hline \multicolumn{7}{|c|}{ Computed discharge for the stilling-well or radial-gates gage minus computed discharge for the AVM gage } \\
\hline $\begin{array}{l}\text { Upper } 95 \% \text { confidence limit for } \\
\text { the mean difference }\end{array}$ & -3.4 & $-2,430$ & -0.4 & 47.1 & 34,070 & 8.3 \\
\hline Mean difference & -61.0 & $-44,140$ & -5.7 & 21.8 & 15,790 & 3.9 \\
\hline $\begin{array}{l}\text { Lower } 95 \% \text { confidence limit for } \\
\text { the mean difference }\end{array}$ & -118.6 & $-85,850$ & -11.2 & -3.4 & $-2,500$ & -0.6 \\
\hline $\begin{array}{l}\text { Sample standard deviation for } \\
\text { difference }\end{array}$ & 58.8 & 42,560 & 5.5 & 25.8 & 18,660 & 4.6 \\
\hline \multicolumn{7}{|c|}{ AVM data corrected for temporal trend } \\
\hline $\begin{array}{l}\text { Upper } 95 \% \text { confidence limit for } \\
\text { the mean difference }\end{array}$ & --- & --- & --- & -26.8 & $-19,370$ & 6.4 \\
\hline Mean difference & --- & --- & --- & 4.6 & 3,310 & 0.6 \\
\hline $\begin{array}{l}\text { Lower } 95 \% \text { confidence limit for } \\
\text { the mean difference }\end{array}$ & --- & --- & --- & 35.9 & 26,000 & -5.2 \\
\hline $\begin{array}{l}\text { Sample standard deviation for } \\
\text { difference }\end{array}$ & --- & --- & --- & 32.0 & 23,150 & 5.9 \\
\hline
\end{tabular}

Instantaneous discharges, 1996-99

Discharge measured by using vertical-axis current meters minus computed discharge for the AVM gage

\begin{tabular}{|c|c|c|c|c|c|}
\hline $\begin{array}{l}\text { Upper } 95 \% \text { confidence limit for } \\
\text { the mean difference }\end{array}$ & -55.6 & $-40,250$ & -4.1 & 42.6 & 30,840 \\
\hline Mean difference & -66.4 & $-48,080$ & -5.0 & 25.9 & 18,760 \\
\hline $\begin{array}{l}\text { Lower } 95 \% \text { confidence limit for } \\
\text { the mean difference }\end{array}$ & -77.2 & $-55,890$ & -5.8 & 9.2 & 6,660 \\
\hline Sample standard deviation for & 53.5 & 38,710 & 4.2 & 28.2 & 20,450 \\
\hline
\end{tabular}
difference

Discharge measured by using a broadband ADCP minus computed discharge for the stilling well or radial-gates gage

Upper $95 \%$ confidence limit for

$63.7-46,120$

4.5

16.5

$-11,950$

$-2.3$ the mean difference

Mean difference

$41.4 \quad 29,990$

3.1

$-24.2$

$-17,520$

$-4.1$

Lower 95\% confidence limit for

$19.1 \quad 13,830$

1.7

$-31.9$

$-23,100$

the mean difference

$76.4 \quad 55,290$

4.8

25.8

18,640 difference

Discharge measured by using a broadband ADCP minus discharge computed from the discharge-rating equation derived as part of this study ${ }^{2}$

\begin{tabular}{|c|c|c|c|c|c|c|}
\hline $\begin{array}{l}\text { Upper } 95 \% \text { confidence limit for } \\
\text { the mean difference }\end{array}$ & 81.6 & 59,080 & 5.3 & -26.1 & $-18,900$ & -3.6 \\
\hline Mean difference & 58.8 & 42,540 & 3.9 & -34.5 & $-25,010$ & -5.5 \\
\hline $\begin{array}{l}\text { Lower } 95 \% \text { confidence limit for } \\
\text { the mean difference }\end{array}$ & 35.9 & 25,990 & 2.4 & -43.0 & $-31,130$ & -7.4 \\
\hline $\begin{array}{l}\text { Sample standard deviation for } \\
\text { difference }\end{array}$ & 78.2 & 56,630 & 5.0 & 28.2 & 20,390 & 6.3 \\
\hline
\end{tabular}


The third method of detecting bias is to examine the data collection and computation procedures for sources of bias. A procedural bias, for example, would be a small negative bias in the data for the AVM gaging station on the Wellton-Mohawk Canal that results from an unshifted discharge rating. The differences in biases for the two stations on the Gila Gravity Main Canal at Imperial Dam (table 21) may also have resulted from procedural biases. In particular, the different methods of making discharge measurements may have different biases. There may be some physical condition at the measuring section that results in a positively biased broadband ADCP discharge measurement. Alternatively, there may be some condition that results in a negative bias for discharges measured by using vertical-axis current meters-perhaps a nonstandard vertical-velocity distribution in the measuring section. The method of measuring discharge with a vertical-axis current meter assumes a standard vertical-velocity distribution (Rantz, 1982a, p. 132-134). For a standard vertical-velocity distribution, the mean of the velocity measured at 0.2 and 0.8 of the total depth equals the mean velocity of the vertical section. If the vertical-velocity distributions for many of the vertical sections across the measuring section are not standard, because of vegetation or hydraulic conditions in the channel, then a bias may result. Biases resulting from a nonstandard vertical-velocity distribution can be determined by comparing the mean velocity at the 0.2 and 0.8 depths of a vertical section to the mean velocity at several (as many as 10) depths evenly distributed through the vertical section (Rantz, 1982a, p. 132-139). The difference in the bias in streamflow at the two gaging stations on the Gila Gravity Main Canal at Imperial Dam could be accounted for if, in the vertical-axis current meter measurements, the mean velocity measured at 0.2 and 0.8 depths is biased negatively (slightly slower) by about 3 percent at most vertical sections across the measuring section.

\section{SUMMARY}

The BOR is currently (1995-2001) testing the LCRAS as a method to estimate the consumptive use of Colorado River water. Consumptive use is estimated in the LCRAS, in part, on the basis of the annual discharge or annual change in reservoir contents, as well as the variance of estimate of the annual discharge or annual change in reservoir contents at several surface-water gaging stations in the lower Colorado River streamflow-gaging network. The standard error of estimate and the variance of estimate were determined for the annual discharge at 14 streamflow-gaging stations and for the annual change in content for 2 reservoir-content gaging stations used for the LCRAS for calendar years 1995-99.

The standard error of the annual discharge was determined by using a modified version of the Moss and Gilroy (1980) method. This method assumes that the uncertainty in the shift of the discharge rating is the main source of uncertainty in computed discharges. The method assumes that the discharge-rating shift behaves as a first-order Markovian process, and that the uncertainty in the discharge-rating shift is dependent on the variance of the discharge measurements used to determine the discharge-rating shift, the variance of the Markovian process, and the serial correlation of the Markovian process. The method applies Kalman-filter theory to determine the standard error of the annual discharge on the basis of the estimates of these three parameters and the frequency of discharge measurements. The Moss and Gilroy method was modified by estimating the measurement variance, process variance, and the serial correlation of the process from a semivariogram of the discharge-rating residuals, rather than estimating the measurement variance by using an empirical method and estimating the process variance and serial correlation of the process from a variogram of the discharge-rating residuals. For some cases in this study, measurement variance could not be determined from the semivariogram of the discharge-rating residuals, and measurement variance was determined on the basis of the error in individual discharge measurements estimated by using the Sauer and Meyer method (1992), which is an updated version of the Carter and Anderson method (1963). At 5 of the 14 streamflow-gaging stations, the measurement variance determined on the basis of the error in individual discharge measurements estimated by using the Sauer and Meyer method (1992) was larger than the

variance of the discharge-rating residuals. These differences indicate that use of the Sauer and Meyer method (1992) can result in overestimated measurement variance. The modified Moss and Gilroy method requires the assumption of unbiased discharge-rating residuals because the mathematics of the Kalman-filter theory do not 
account for bias. Bias in the discharge measurements at a given station, if any, will be propagated to the dischargerating residuals but will not be accounted for. For this reason, the standard errors presented in this report only represent the random error in the annual discharge data.

The standard error of the annual change in reservoir content was determined on the basis of the reservoirsurface area and the standard error of the reservoir-stage readings. Uncertainty in the reservoir content result when the reservoir-surface elevation at the gaging station is not representative of the entire reservoir surface.

The standard error of the annual discharge, as a percentage, ranged from 0.11 percent for the All-American Canal near Imperial Dam in 1998 to 12.26 percent for the Colorado River below Imperial Dam in 1996. The standard error of the annual discharge, as a percentage, was less than 2 percent for all 5 years for 11 of the 14 streamflow-gaging stations. The variance of estimate of the annual discharge ranged from 9,430 acre- $\mathrm{ft}^{2}$ for the Mittry Lake Diversions in 1995 to 6,040 million acre- $\mathrm{ft}^{2}$ for the Colorado River at the NIB in 1998. In general, the standard error of the annual discharge, as a percentage, was smallest at stations on the main stem of the Colorado River; however, the variance of estimate of the annual discharge was largest at these stations because of the large annual discharge on the main stem. The variance of estimate of the annual change in content for the two reservoirs ranged from 2.545 million acre- $\mathrm{ft}^{2}$ for Lake Havasu in 1996 to 7.770 million acre- $\mathrm{ft}^{2}$ for Lake Mohave in 1995 .

The variance of estimate of the annual discharge for a streamflow-gaging station can be reduced by making additional discharge measurements; either by increasing the number of discharge measurements made per site visit, or by increasing the frequency of site visits. Measurement error can be reduced by using the average discharge for two or more discharge measurements made during a site visit. For a station where measurement variance is much greater than process variance and the serial correlation of the discharge-rating residuals is high, the stream-gaging strategy would involve making multiple discharge measurements per site visit. In contrast, for a streamflow-gaging station where process variance is much greater than measurement variance and the serial correlation of dischargerating residuals is low, the gaging strategy would consist of several single discharge measurement site visits. For a given operating cost or for a given variance of estimate of the annual discharge at a streamflow-gaging station, the optimal site-visit and discharge measurement-strategy can be determined, providing that the travel costs as well as the measurement variance, process variance, and serial correlation of discharge-rating residuals are known.

\section{SELECTED REFERENCES}

Bureau of Reclamation, 1965-2000, Compilations of records in accordance with Article V of the Decree of the Supreme Court of the United States in Arizona vs. California dated March 9, 1964, calendar year 1965-99: Bureau of Reclamation duplicated report (published annually).

1998, Lower Colorado River Accounting System, demonstration of technology, calendar year 1996: U.S. Department of the Interior, Bureau of Reclamation, Lower Colorado River Regional Office, Boulder City, Nevada, 48 p., 6 attachments, 1 appendix.

2000, Lower Colorado River Accounting System, demonstration of technology, calendar year 1999: Department of the Interior, Bureau of Reclamation, Lower Colorado River Regional Office, Boulder City, Nevada, 48 p. +11 exhibits, 90 attachments.

Burkham, D.E., and Dawdy, D.R., 1968, Error analysis of streamflow data for an alluvial stream: U.S. Geological Survey Professional Paper 655-C, 13 p.

Carter, R.W., and Anderson, I.E., 1963, Accuracy of current meter measurements: American Society of Civil Engineers Proceedings, Journal of the Hydraulics Division, v. 89, no. HY4, p. 105-115.

Chiles, Jean-Paul, and Delfiner, Pierre, 1999, Geostatistics, modeling spatial uncertainty: John Wiley \& Sons, Inc., New York, New York, $695 \mathrm{p}$.

Cleveland, W.S., 1979, Robust locally weighted regression and smoothing scatterplots: Journal of the American Statistics Association, v. 74, p. 829-836.

Condes de la Torre, Alberto, 1982, Support by the U.S. Geological Survey for adjudications, compacts, and treaties: U.S. Geological Survey Open-File Report 82-680, 24 p.

Fontaine, R.A., 1983, Uncertainties in records of annual mean discharge in Maine: U.S. Geological Survey Water-Resources Investigations Report 83-4025, 108 p.

Fontaine, R.A., Moss, M.E., Smath, J.A., and Thomas, W.O., Jr., 1984, Cost effectiveness of the stream-gaging program in Maine-A prototype of nationwide implementation: U.S. Geological Survey Water-Supply Paper 2244, 39 p. 
Gelb, Arthur, ed., 1974, Applied optimal estimation: Cambridge, The Massachusetts Institute of Technology Press, 374 p.

Gilroy, E.J., 1982, Computer procedures for determining cost-effective stream gaging strategies: unpublished data on file in the Surface-Water Branch, U.S. Geological Survey, Reston, Virginia.

Madigan, M.F., and Weiss, J.S., 1996, Real time applications of acoustic velocity meters along the Lower Colorado River: Bureau of Reclamation, Lower Colorado Regional Office, Boulder City, Nevada, final draft, March 1996, 38 p.

MathSoft, 2000a, S-Plus 2000 Professional Edition for Windows, Release 3. 2000b, Spatial Statistics Module for S-Plus 2000, Release 1.5.

Millard, S.P., 2001, Environmental statistics with S-Plus: Boca Raton, Florida, CRC Press, 830 p.

Moss, M.E., and Gilroy, E.J., 1980, Cost-effective stream-gaging strategies for the Lower Colorado River Basin: The Blythe Field Office Operations: U.S. Geological Survey Open-File Report 80-1048, 112 p.

Owen-Joyce, S.J., and Raymond, L.H., 1996, An accounting system for water and consumptive use along the Colorado River, Hoover Dam to Mexico: U.S. Geological Survey Water-Supply Paper 2407, 94 p.

Rantz, S.E., 1982a, Measurement and computation of streamflow-Volume 1, measurement of stage and discharge: U.S. Geological Survey Water-Supply Paper 2175, 284 p. 1982b, Measurement and computation of streamflow—Volume 2, computation of discharge: U.S. Geological Survey Water-Supply Paper 2175, 397 p.

Sauer, V.B., and Meyer, R.W., 1992, Determination of error in individual discharge measurements: U.S. Geological Survey Open-File Report 92-144, 21 p.

Tadayon, Saeid, Duet, N.R., Fisk, G.G., McCormack, H.F., Partin, C.K., Pope, G.L., and Rigas, P.D., 2000, Water resources data, Arizona, water year 1999: U.S. Geological Survey Water-Data Report AZ-99-1, 370 p.

Thomas, W.O., and Gilroy, E.J., 1984, Computer procedures for determining cost-effective stream-gaging strategies: U.S. Geological Survey, (unpublished internal report).

U.S. Congress, 1948, The Hoover Dam documents: U.S. Congress, 80th, 2nd session, House Document No. 717, 936 p.

U.S. Supreme Court, 1964, State of Arizona, plaintiff vs. State of California et al., defendants: Decree-March 9, 1964, no. 8, original, $14 \mathrm{p}$.

Wahlin, B.T., Replogle, J.A., and Clemmens, A.J., 1997, Measurement accuracy for major surface-water flows entering and leaving the Imperial Valley: U.S. Department of Agriculture, Agricultural Research Service, WCL Report 23, 79 p. 